\title{
OF BREAD AND ROSES AND COPYRIGHTS
}

\author{
LINDA J. LACEY*
}

\section{INTRODUCTION}

The current theory of American copyright law represents an unsuccessful attempt to impose sociahist ideals upon a capitalist framework. ${ }^{1}$ We are imitially told that it is necessary to create "intellectual property"2 rights in a work of art so that the artist ${ }^{3}$ will be financially rewarded for her work. Without this reward, the theory goes, she will lose the incentive to produce more works of art and the "progress of science and the

* Associate Professor of Law, The University of Tulsa College of Law; B.S., University of Wisconsin at Madison, 1967; J.D., UCLA School of Law, 1978. I would like to thank Taunya Banks, Marianne Blair, Richard Delgado, Gilbert Gaynor, Don Gjerdingen, Marc Linden, Pierre Schlag, Wimona Tanaka, and Marilyn Yarborough for their useful comments on various drafts of this paper. Barbara Eden, Kate Reeves, Craig Refner, and Kelly Weaver provided invaluable research assistance. I am particularly grateful to Laura Gonsalves, Umiversity of Tulsa Law School Class of 1990. In addition to her exceptionally thorough and creative researcl assistance, she consistently gave me insightful criticisms and suggestions that contributed greatly to the final version of this Article.

1. The MCGRAW-HILI Dictionary OF MODERN ECONOMICS 193, 427 (3rd ed. 1983), provides useful, relatively objective definitions of the terms:

Capitalism. An eeonomic system characterized by private ownerslip and initiative. Basic to a free enterprise, or capitalist, system is the concept of private property, the right of ownership and use of wealth to earn income. From private property comes the institution of private enterprise or production by privately owned businesses. Firms are free to hire, produce, and price as they see fit. Furthermore, there is private initiative to carry on production. The motive for this private initiative is the desire of the owners of business firms to earn profits.

Socialism. An economic and political system the basis of which is the abolition of private property and the public ownership and operation of the means of production. Whereas capitalism reeognizes the relatively unrestricted right of private ownerslip of productive factors, socialism reserves the ownership of factors for the cominunity as a whole .... Another major aspect of socialism is the redistribution of income for the purpose of achieving equality for all. This welfare consideration is summed up in the phrase "from each according to his abilities, to each aceordimg to his needs."

2. Intellectual property law is also regarded as encompassing "industrial property" such as patents and trademarks. See generally P. GoldsteIN, CASES AND MATERIALS ON THE LAW OF INTELLECTUAL PROPERTY xix (2d ed. 1981) (noting that all three areas "occupy a common ground, eacl seeking to stimulate mvestment in information by awarding property rights to products of the mind"). The text of this Article will be concerned exclusively witl copyright law; however I will occasionally refer to the other types of intellectual property in the footnotes. The term intellectual property also can refer to ideas, which are not protected by copyriglt law, see infra note 252 and accompanying text, but are protected by a body of law known as idea law, see generally $3 \mathrm{M}$. NIMMER \& D. NimMER, NimMER ON COPYRIGHT cli. 16 (1989).

3. The term "artist" is used in its broadest sense to include writers, sculptors, choreographers, etc.-anyone who creates a product that can be protected by copyright law. 
useful arts"4 will be severely impeded. This einphasis on a monetary incentive is boilerplate micro-economic analysis. ${ }^{5}$

At this point, copyright theory shifts abruptly froin an einphasis on individuahisin to an emphasis on altruisin. ${ }^{6}$ The artist is told that the "public interest" mandates that intellectual property inust be treated differently froin other types of property. ${ }^{7}$ The artist finds she has a duty to share her work with other artists, because artists gather their inspiration froin the works of others-"a dwarf standing on the shoulders of a giant can see further than the giant himself." 8 This duty has created the ainorphous "fair use" defense, which allows others to copy an artist's work for

4. The copyright clause of the U.S. Constitution states: "The Congress shall have Power . . . to Promote the Progress of Science and useful Arts, by securing for limited Times to Authors and Inventors the exclusive Right to their respective Writings and Discoveries." U.S. CoNST. art. I, § 8.

5. See, e.g., F. Pryor, A Guidebook to the Comparative Study of Economic SysTEMS 21 (1985) ("In capitalism the major driving forces for undertaking econoumic activities are material incentives (e.g. additional income) and production is primarily motivated for the sake of profit."). The celebrated ecouomists Milton and Rose Friedman state that

[o]ne of the beauties of a free price system is that the prices that bring the imfornation also provide both an incentive to react to the infonnation and the means to do so. ... Prices also provide an incentive to act on infonnation not only about the demand for the output but also about the most efficient way to produce a product.

M. Freidman \& R. Friedman, Free to Choose: A Personal Statement 18 (1980).

6. The observation that any area of the law embodies a confiict between individualism and altruism is hardly novel after Duncan Kennedy's seminal work, Form \& Substance in Private Law Adjudication, 89 HARV. L. REv. 1685, 1713-22 (1976). However, copyright law is unique in that its basic theory explicitly creates this conflict.

7. To my knowledge, no country treats copyrighted works exactly the same as other forns of property. The Berne Convention, an international copyright treaty subscribed to by 77 countries, see infra note 70, recognizes the time duration limitation and a form of fair use. See 4 M. NIMMER \& D. NIMMER, supra note 2, at app. 27. Other types of intellectual property such as trademarks, patents, and trade secrets also are subject to certam limitations, set out in their own body of law. See generally D. Chisum, Intellectual Property: Copyright, Patent and Trademark Law (1980). None of these limitations, however, are as broad as the fair use defense. See infra notes 5866 and accompanying text.

8. This famous aphorism, used by creative minds from Sir Issac Newton to Albert Eistein, served as the title of a book, R. MERTON, ON THE Shoulders of GiANTS (1965); see also Chafee, Reflections on the Law of Copyright, 65 CoLUM. L. REV. 502, 511 (1945). The idea that artists must feel free to borrow from the work of others has ancient roots. The poet Heinrich Heine wrote:

Nothing is sillier than this charge of plagarism. There is no sixth commandment in art. The poet dares help himself wherever he lists-wherever he finds material suitable to his work. He may even appropriate entire columns with their carved temples, if the temple he thus supports be a beautiful one. Goethe understood this very well, and so did Shakespeare before him.

The New Dictionary of Thoughts 483 (T. Edwards ed. 1977).

The concept that artists have a special role to play in society is also widely acknowledged. Jennifer Jaff observes that

[a]rtists are more than imitators; they are teachers. They help us to understand our place in history, and express for us our essences and the essence of our existence. In this sense, artists are the "watchful ones" whose role it is to provide us with a mirror in which to see ourselves as we really are.

Jaff, Law and Lawyer in Pop Music: A Reason for Self-Reflection, 40 U. MIAMI L. REV. 659, 670 (1986) (footnotes omitted). 
free without her permission when the circumstances are right. ${ }^{9}$ Additionally, intellectual property rights, unlike other types of property rights, never last imto perpetuity - they last only for the lifetime of the author, plus a specified number of years. ${ }^{10}$

None of these contradictory principles have been questioned seriously by current copyright scholars. ${ }^{11}$ Monroe Price has observed that

9. See infra notes 59-66 and accompanying text. The fair use defense and the appropriate perimeters of that defense are the most popular topic in copyright literature. The most important articles in the area, inciude: Cirace, When Does Complete Copying of Copyrighted Works for Purposes Other Than for Profit or Sale Constitute Fair Use? An Economic Analysis of the Sony Betamax and Williams \& Wilkins Cases, 28 ST. Louis U.L.J. 647 (1984); Fisher, Reconstructing the Fair Use Doctrine, 101 HARv. L. REv. 1659 (1988); Francione, Facing The Nation: The Standards for Copyright Infringement and Fair Use for Factual Works, 134 U. PA. L. REv. 519 (1986); Gordon, Fair Use as Market Failure: A Structural and Economic Analysis of the Betamax Case and its Predecessors, 82 Colum. L. REv. 1600 (1982); Raskind, A Functional Interpretation of Fair Use, 31 J. CopyRIGHT Soc. 600 (1984); Sinclair, Fair Use Old and New: The Betamax Case and its Forebears, 33 Buffalo L. Rev. 269 (1984); Walker, Fair Use: The Adjustable Tool for Maintaining Copyright Equilibrium, 43 LA. L. REv. 735 (1983).

This subject has generated a seemingly endless stream of law review articles. A printout from the Infotrac, a computer list of law review articles written since 1980, reveals 43 articles on the subject of "fair use (cases)," 18 on the subject of "fair use (analysis)," 66 articles on the subject "fair use (law and legislation)," and 55 on the subject "fair use (litigation)." Even allowing for overlap, that list demonstrates a substantial number of articles published on fair use since 1980. See also $3 \mathrm{M}$. Nimmer \& D. NimMER, supra note 2, § 13.05; L. SELTZER, EXEMPTIONS AND FAIR USE IN COPYRIGHT (1977).

An additional series of articles discuss the the hypothetical conflict between copyright and the first amendment. See, eg., Denicola, Copyright and Free Speech. Constitutional Limitations on the Protection of Expression, 67 CALIF. L. REv. 283 (1979); Goldstein, Copyright and the First Amendment, 70 Colum. L. REV. 983 (1970); Nimmer, Does Copyright Abridge the First Amendment Guarantees of Free Speech and Press?, 17 UCLA L. REv. 1180 (1970); Sobel, Copyright and the First Amendment: A Gathering Storm?, CopYRIGHT LAW Symposium (ASCAP) 43 (1971); Comment, Copyright and the First Amendment: Where Lies the Public Interest?, 59 TuL. L. Rev. 135 (1984); Note, Copyright, Free Speech and the Visual Arts, 93 Y ALE L.J. 1565 (1984). Most commentators argue that a first amendment defense should be separate from a fair use defense. However, the approach of the Supreme Court to date has been to consider first amendment defenses to copyright infringement as a component of the fair use defense. See infra note 252 .

10. See infra notes $67-77$ and accompanying text.

11. Only one major copyright article has questioned the very existence of copyright law: Breyer, The Uneasy Case for Copyright: A Study of Copyright in Books, Photocopies, and Computer Programs, 84 HARV. L. REv. 281 (1970). Stephen Breyer's basic premise is that even without copyright protection book publishers would continue to publish, artists would still be compensated, and the public would be served by access to less expensive books. Breyer ultimately concludes that although abolishing copyright "would not produce a very large or a very harmful decline in most kinds of book production," there also is no demonstrated need to actually abolish protection. $1 d$. at 321. He summarizes his ultimate position of the desirability of copyright law as "ambivalent." Id. at 322. Breyer's basic arguments about the economic effects of a potential removal of copyright are challenged in Tyerman, The Economic Rationale for Copyright Protection for Published Books: A Reply to Professor Breyer, 18 UCLA L. Rev. 1100 (1971).

Although Breyer's article appears to be a real challenge to copyright theory, it actually legitimizes one important aspect of the status quo-the assumption that artists create exclusively for economic reasons. Moreover, he does not address the important question of moral rights or a definition of the "public interest" supposedly served by copyright law. 
although modern writers have attacked the "regular way of looking at things"12 in almost every other area of the law, thus far intellectual property law has remained relatively unscathed. Copyright scholars also have managed to avoid asking an obvious, but uncomfortable question: If the reasons intellectual property should be shared with others are so compelling, why do they not apply with equal force to other forms of private property? Thus, they fail to confront the iromic fact that in this country

12. Price, Reexamining Intellectual Property Concepts: $A$ Glimpse into the Future Through the Prism of Chakraberty, 6 CARdozo ARTS \& ENT. L.J. 443, 443 (1988). He suggests this lack of serious questioning may be "because in the world of legal education, copyright scholars, except for the very few such as Professor Nimmer, do not hold the political positions as Kings of the academic mountain necessary for fulfillment of the inevitable assault by the young." Id.

Copyright law increasingly has drawn the attention of law and economists, who do provide a different framework for analysis of copyright issues. See, e.g., Landes \& Posner, An Economic Analysis of Copyright Law, 18 J. LEG. STudies 325 (1989); Cirace, supra note 9, at 658-81 (utilizing a framework based on theory of the firm, opporturity cost, consumption externalities, and price discrimination to detemine extent of harm and fair use); Fisher, supra note 9, at 1698-1795 (examining fair use with economic utopian analysis); Gordon, supra note 9, at 1614-27 (suggesting three-part test for determining fair use when the inarket fails); Raskind, supra note 9, at 626-39 (proposing that applied market principles provide an alternative formulation of fair use). However, these writers completely accept the financial incentive theory and do not question the actual existence of the limitations on intelleetual property.

The move to economic analysis of copyriglit problems is often done very well, and appears to offer a solid objective inethod to confront some of the area's uncertainties. But even if the marketplace approach is well-suited to analyze the artists' interests, a concept I will later dispute, see infra notes 187-210 and accompanying text, it is poorly suited to analyze society's interest in works of art. Economic analysis is at its best when applied to purely inonetary transactions, and it is at its worst when applied to elusive concepts like art and bcauty. Although law-and-economists claim that their analysis can be applied to all sorts of intangible areas, such as marital love, see, e.g., R. POSNER, ECONOMIC ANALYSIS OF LAW 127-46 (3d ed. 1986), their attempts to perform this feat are usually eitler lighly offensive, $i d$. at 202 (comparing rape to a coerced transaction and arguing that the prevention of rape is necessary to preserve the marriage market), or just plam ridiculous, $i d$. at 130 31 (comparing marriage to farmers applying clemicals to their soil). The language of art and the understanding of its effect on umiversal cominunal values and personal self-fulfillment simply do not translate into "economist speak." Consider Edna St. Vincent Millay's eloquent description of a concert:

My body will die in its chair,

And over my head a flame,

A mind that is twice my own,

Will mark witl icy mirtlı

The wise advance and retreat

Of armies without a country....

I will come back to you,

I swear I will

And you shall know me still

I shall only be a little taller

Than when I left.

E. Millay, The Concert, in Collected Lyrics of Edna St. Vincent Millay 146 (1939). These images do not lend themselves easily to the Coase Theorem. 
our legal system scatters free artistic roses to people often deprived of bread. ${ }^{13}$

I begin this Article by asking the question that others feel is better left unasked: How can we justify restrictions on property rights for artists but not for other property holders? I hope my discussion will help readers to understand the arbitrary and illogical nature of our assumptions about private property. We learn in law school to accept the idea that intellectual property ownership should be himited in time and be available for free use by deserving people because these limitations have always been there, but any attempt to extend them to other forms of property would strike most people as dangerous and unnatural.

In the next section, $I$ also question the validity of the universal assumption that financial incentives are the only reason artists create works of art. ${ }^{14}$ Although this paper is not a feminist article in the sense that it is not about issues of patriarchy, 15 in this section in particular I rely upon fernimist inethodology. ${ }^{16}$ The feminist insight that universal, "objective" statements about human nature are really just illusions created by middle-class white males ${ }^{17}$ is central to my conclusion that artists work for a

13. Audre Lord writes that "[in our] world ... most people-certainly most Black people-are on a bread concern level.... If you conquer the bread problem, that gives you at least a chance to look around at the others." A. LORD, SISTER OUTSIDER 34 (1984), quoted in Matsuda, Looking To The Bottom: Critical Legal Studies and Reparations, 22 HARV. C.R.-C.L. L. REV. 322, 325 n.12 (1987).

14. See infra notes $182-210$ and accompanying text.

15. Definitions of feminist jurisprudence vary, but most people agree that it is centered around discussions of women's position in a patriarchial society and the means of eliminating patriarchy. See, e.g., Finley, The Nature of Domination and The Nature of Women: Refiection on Feminism Unmodified, 82 Nw. L. REv. 352, 353 (1988) ("The purpose and practice of feminist theory is to name, expose, and eliminate the unequal position of woinen in society."); Bender, Feminist Theory and Tort, 38 J. LEG. ED. 3, 8 (1988) ("The primary task of feminist scholars is to awaken women and men to the invidious ways in which patriarchy distorts all our lives."). Robin West explains that:

["F]eminist jurisprudence" consists of two discrete projects. The first project is the unmasking and critiquing of the patriarchy behind purportedly ungendered law and theory, or, put differently, the uncovering of what we might call "patriarchal jurisprudence" from under the protective covering of "jurisprudence".... The second project in which feminist legal theorists engage might be called "reconstructive jurisprudence." The last twenty years have seen a substantial amount of feminist law reform, primarily in the areas of rape, sexual harassment, reproductive freedom, and pregnancy rights in the workplace.

West, Jurisprudence and Gender, 55 U. CHI. L. REv. 1, 60 (1988).

16. For descriptions of feminist methodology, see Bender, supra note 15, at 4-12; Matsuda, Liberal Jurisprudence and Abstracted Visions of Human Nature: A Feminist Critique of Rawls' Theory of Justice, 16 N.M.L. Rev. 613, 617.22 (1986); Scales, The Emergence of Feminist Jurisprudence: An Essay, 95 YALE L.J. 1373 (1986) (discussing the impossibility of discovering solutions to inequality through abstraction).

17. Mari Matsuda gives us a powerful criticism of universalities in her discussion of Rawls' Theory of Justice. She argues that Rawls' use of abstraction results in his failure to present a meaningful theory of justice. Matsuda, supra note 16, at 614-17, 624-30. 
variety of reasons and therefore the base assumption of copyright law is seriously flawed. ${ }^{18}$ I also argue that if we really are interested in artists' actual needs, we should recognize the European concept of moral rights, ${ }^{19}$ which preserve the bond between the artist and her work. ${ }^{20}$

Finally, I look at the abstract and seldom-defined concept of the "public interest." I argue that there are at least two ineamings for this term, one based on traditional liberal theory and the other on commumitarian ideals. I conclude that particularly in the context of the fair use defense, only the comnunitarian interpretation is consistent with the purposes of copyright laws. ${ }^{21}$

18. See infra notes $182-210$ and accompanying text. To support this conclusion, I use feminist methodology by telling the "story" of four hypothetical artists. Most feminists believe that "the personal is the political"- - that our own experiences and stories of other women's lives help us understand the oppressive nature and effects of patriarchial institutions far more successfully than abstract generalities. See, e.g., Karst, Women's Constitution, 1984 DukE L.J. 447, 495-505 (arguing for a conception of justice grounded in the needs of real people); Matsuda, supra note 16, at 617-24 ("[t]ime and again women have found their own experiences are more valuable truth tools than the abstractions of others"); Bender, supra note 15, at 29-30 ("women's moral development reflects a focus on responsibility and contextuality, as opposed to men's which relies more heavily on right and abstract justice").

19. The subject of the desirability of moral rights has been discussed at length in a number of articles. However, these articles do not discuss moral rights in the context of the basic assumptions regarding the artist's motivation for producing works of art and the need for limitations on copyright to protect the public iuterest. See infra notes 222-28, 261-68 and accompanying text. The major works discussing moral rights are Damich, The New York Artists'Authorship Rights Act: A Comparative Critique, 84 Colum. L. Rev. 1733 (1984); Da Silva, Droit Moral and the Amoral Copyright: $A$ Comparison of Artists' Rights in France and the United States, 28 Bull. CoPYRiGHT Soc'y 1 (1980); Gantz, Protecting Artists'Moral Rights: A Critique of the California Art Preservation Act as a Model for Statutory Reform, 49 GEO. WASH. L. REv. 873 (1981); Kwall, Copyright and the Moral Right: Is an American Marriage Possible?, 38 VAND. L. REv. 1 (1985); Merryman, The Refrigerator of Bernard Buffet, 27 Hastings L.J. 1023 (1976); Price, Government Policy and Economic Security for Artists: The Case of the Droit de Suite, 77 YALE L.J. 1333 (1968); Sarraute, Current Theory on the Moral Right of Authors and Artists Under French Law, 16 AM. J. CoMP. L. 465 (1968); Treece, American Law Analogues of an Author's "Moral Right," 16 AM. J. CoMP. L. 487 (1968).

20. Although I argue for the extension of a unique type of rights for artists, like many feminists, I am ambivalent on the subject of rights. As Robin West puts it: "[F]eminists understand, and even sympathize with, critieal legal theory's rights critique, but will never endorse it." West, supra note 15, at 55. The Critieal Legal Studies' rejection of "rights" also has been criticized by prominent minority commentators. Richard Delgado provides a powerful criticism of this aspect of CLS theory in Delgado, The Ethereal Scholar: Does Critical Legal Studies Have What Minorities Want, 22 HARV. C.R.-C.L. L. REV. 301, 303-07 (1987). Delgado argues that the average crit, "a white male teaching at a major law school," does not really need rights in his daily life, since he has never experienced discrimination. Thus, these male professors are able to create a theoretical rejection of rights, ignoring the fact that for others rights analysis has been crucial to their struggle for equality. As Delgado puts it: "For minorities they are invigorating cloaks of safety that unite us in a common bond." Id. at 306-07.

21. See infra notes $226-58$ and accompanying text. 


\section{Why Is Intellectual Property Different From Other FORMS OF PROPERTY?}

\section{A. Introduction}

A baker bakes a loaf of bread, his wife builds a wooden breadbox, his son writes a poem about the bread, and his daughter paints an oil still life of the bread and breadbox. All four people have worked to create something that can be considered property. Yet there are obvious differences in the products. We intuitively accept the statement that the bread, the breadbox, and the oil painting are property. We also easily accept the idea that the son owns the piece of paper on which the poem is written. But although an artistic work must be "fixed" in a tangible means of expression to be protected by the law, 22 it is not the physical fixation im the form of words on a particular piece of paper, but rather the intangible images created by the arrangement of the words, that are considered valuable. ${ }^{23}$ If copyright law simply gave an author absolute control over his original manuscript and still allowed others to freely copy its words, then it would have created an empty property interest. ${ }^{24}$ The possession of intellectual property therefore consists of a collection of rights that create a legal relationship between a copyright holder and anyone who wishes to use his works. ${ }^{25}$ The Copyright Act allows the owner of a copyrighted work exclusive rights:

(1) to reproduce the copyrighted work in copies and phonorecords;

22. 17 U.S.C. $\$ 102(a)$ (1988). The word "fixed" is explained in the statute as follows: "[Works are] ... fixed in any tangible medium of expression now known or later from which they can be perceived, reproduced, or otherwise communicated, either with the aid of a machine or device." Id.

23. The assumption that certain rights are valuable and therefore should be property, ultimately may lead to the type of circular thinking described in Cohen, Transcendental Nonsense and the Functional Approach, 35 CoLuM. L. REV. 809, 814-18 (1935). Cohen explains that while courts purport to provide legal protection for an entity based on its economic value, in reality the economic value is dependent on the extent of the courts' protection. Id. at 815 . Cohen's article, a classic of legal realism, states that legal arguments using legal concepts like "corporate entity" or "property rights" are necessarily circular, since these terms are themselves creations of law. Id. at 820 .

24. Obviously, this statement does not hold true for all types of works of art, particularly paintings, where the artist's primary income will come from the sale of the original. Therefore, there is a common perception that copyright law more fully protects the interests of the writer than the painter. See Price, supra note 19, at 1342-43. Monroe Price argues that this perception is not necessarily accurate because few artists and sculpturers actually copyright their work. Therefore, it is difficult to ascertain the degree of protection the law would provide if utilized. Id. at 1343-44.

25. Wesley Newfield Hohfeld is regarded as the most influential architect of the concept of property as a set of fundamental legal relations. See generally Hohfeld, Some Fundamental Legal Conceptions as Applied in Judicial Reasoning, 23 YALE L.J. 16 (1913). Hohfeld recognized that property was not limited to tangible objects, and all property interests could be limited. For an excellent discussion of the Hohfeldian concept of property, see generally Vandevelde, The New Property of the Nineteenth Century: The Development of the Modern Concept of Property, 29 BuFfaLo L. REV. 325, 359-62 (1980). 
(2) to prepare derivative works based upon the copyrighted work;

(3) to distribute copies or phonorecords of the copyrighted work to the public by sale or other transfer of ownership, or by rental, lease, or lending;

(4) in the case of hiterary, musical, dramatic, and choreographic works, pantoinimes, and motion pictures and other audiovisual works, perform the copyrighted work publicly; and

(5) in the case of hiterary, inusical, dramatic and choreographic works, pantoinimes, and pictorial, graphic, or sculptured works, including the individual images of a motion picture or other audiovisual work, to display the copyrighted work publicly. ${ }^{26}$

\section{B. Historical Origins of the Idea of Intellectual Property}

There are three broad theories that explain why ownership of intangible rights such as those protected by the Copyright Act should be considered private property. Copyright can be considered either (1) a "natural" right, (2) an artificial right created by the legislature and the judiciary, or (3) a "personal" right integral to an artist's very identity.

The natural rights theory is based on the idea that "whenever one mingles his effort with the raw stuff of the world, any resulting product ought-simply ought-to be his." 27 This proposition was central to the writings of John Locke, who argued that a worker should possess the fruits of his labor. ${ }^{28}$ Translating this concept into copyright theory, Herbert Spenser wrote: "That a inan's right to the produce of his brain is equally vahd with his right to the produce of his hands, is a fact which has yet obtained but a very imperfect recognition."29 Blackstone also drew heavily on Locke's theory when discussing copyright law in his

26. 17 U.S.C. $\S 106$ (1988). Section 102 further states that:

(a) Copyright protection subsists, in accordance with this title, in original works of authorship fixed in any tangible medium of expression, now known or later developed, from which they can be perceived, reproduced, or otherwise communicated, either directly or with the aid of a machine or device. Works of authorship include the following categories:

(1) literary works;

(2) musical works, including any accompanying words;

(3) dramatic works, including any accompanying music;

(4) pantomimes and choreographic works;

(5) pictorial, graphic, and sculptural works;

(6) motion pictures and other audiovisual works; and

(7) sound recordings.

Id. $\S 102$.

For a comprehensive discussion of works that may be protected by copyright, see Nimmer, The Subject Matter of Copyright Under the Act of 1976, 24 UCLA L. REv. 978 (1977).

27. Michelman, Property, Utility and Fairness: Comments on the Ethical Foundations of "Just Compensation" Law, 80 HARV. L. REV. 1165, 1204 (1967).

28. J. Locke, Second Treatise of Government, in Two Treatises of GOVERNMENT ch. 5 $\S \S$ 27-30. (P. Laslett ed. 1960).

29. H. SPENSER, Social Statics 68 (rev. ed. 1896). 
treatise, ${ }^{30}$ stating " $[w]$ hen a man, by the exertion of his rational powers has produced an original work, he seems to clearly have a right to dispose of that identical work as he pleases, and any attempt to vary the disposition he has made of it, appears to be an invasion of that right [of property]."31

Melville Nimmer, author of the leading copyright treatise, also appeared to be a proponent of the natural rights theory, ${ }^{32}$ as is David Ladd, a recent Copyright Register. ${ }^{33}$ But Benjamin Kaplan offers an important opposing view-im his opinion the real natural right to an artistic work belongs to those who would copy it in order to enrich their own work:

[I]f man has any "natural" rights, not the least must be a right to imitate his fellows, and thus to reap where he has not sown. Education, after all, proceeds from a kind of mimicry, and "progress," if it is not entirely an illusion, depends on generous indulgence of copying. ${ }^{34}$

Other commentators and historians argue vigorously that there never has been such a thing as a "natural" right in intellectual property, that any protection an artist enjoys exists solely through the prerogative of the legislature. ${ }^{35}$ These commentators argue that this right was created not to serve the interests of the artist but those of the public. ${ }^{36}$

30. 2 W. Blackstone, CCMmENTARies ON THE LaWS OF ENGLAND *405.

31. Id. at *405-06. Disraeli gave a strong statement of this viewpoint in a parliamentary debate: "[T]hey constituted a species of property better than any other. The tenure of that property was not fictitious; it was primitive; it was the most natural and the least liable to be disputed." 42 PARL. Deb. (3d ser.) 575 (1838). In Millar v. Taylor, 4 Burr. (4th ed.) 2303, 98 Eng. Rep. 201 (K.B. 1769), the first major English common law copyright case, Lord Mansfield argued in favor of property rights for authors using a natural rights analysis: "Because it is just, that an author should reap the pecuniary profits of his own ingenuity and labour." Id. 98 Eng. Rep. at 252 (emphasis in original).

32. 1 M. Nimmer \& D. Nimmer, supra note 2, § 1.03[A]. Nimmer wrote: "The fruits of an author's labor seem to be no less deserving of the privileges and status of 'property' than are the more tangible creative efforts of other laborers." Id.

33. Ladd, The Harm of the Concept of Harm in Copyright, $30 \mathrm{~J}$. COPYRIGHT SOc'Y 421,422 (1983). Ladd acknowledges that the natural rights concept, which he links to the personality theory, has not "generally" been accepted in the United States, but states that the theory does "express a felt sense of what is right and just." Id. at 425 . He argues that the Founding Fathers were heavily influenced by Locke and accepted his ideas on property, quoting Thomas Paine who wrote "to treat letters in any other light than this, is to banish them from the country, or strangle them in the birth." Id. at 426.

34. B. KAPLAN, AN UNHURRied VIEW OF Copyright 2 (1967).

35. The most thorough historical analysis of the origin of common law copyright is Abrams, The Historic Foundation of American Copyright Law: Exploding the Myth of Common Law Copyright, 29 WAYNE L. REv. 1119 (1983). Professor Abrams forcefully states that "[t]here is no historical justification whatsoever for the claim that copyright was recognized as a common law right of an author." Id. at 1128. Although Sinclair apparently accepts Abrams' arguments, Sinclair, supra note 9 , at $269,271 \mathrm{n} .13$, other scholars continue to believe in common law copyright.

36. Breyer emphatically rejects the idea that an author's creation should be property, claiming that "[w]e do not ordinarily create or modify property rights, nor even award compensation, solely on the basis of labor expended." Breyer, supra note 11, at 289. 
The Supreme Court has apparently adopted this theory; it has stated "the copyright is the creature of the Federal statute passed ... [by] Congress .... [T] he Congress did not sanction an existing right but created a new one." 37 The wording of the copyright clause of the Constitution appears to support the Court's contention: it authorizes Congress to create copyright laws (suggesting that no common law or natural law exists) for the purpose of promoting "the Progress of Science and the useful Arts"38_a purpose that focuses solely on the public interest.

One stumblimg block to the theory that copyright is a relatively recent, legislatively-created riglit is the possible existence of an English common law copyright for unpublished works. Historians do not agree about whether this right was ever recognized. ${ }^{39}$ Natural right theorists argue that support for their concept goes back as far as the sixth century, citing the famous case in which an Irish monk made a copy of his former teacher's Psalter. The legendary King Diarmid decided the case for the teacher by stating, "to every cow her calf, and accordingly to every book its copy"-a graphic statement of the fruits-of-the-creator's-labor natural law theory. ${ }^{40}$ Others argue that this story is just a pleasant myth. ${ }^{41}$ Blackstone also acknowledged the uncertainty about common law copyright, but avoided taking sides by simply claiming that "whatever inherent copyright might have been supposed to subsist by the coinmon law," there is now a statutory creation of copyright law that resolves the matter. ${ }^{42}$

The third theory of intellectual property comes primarily from the works of Hegel, who viewed property as "the embodiment of personality."43 Intellectual property theorists, following Hegel's44 and Kant's ${ }^{45}$ thoughts on the subject, contend that the personhood theory of

37. Fox Film Corp. v. Doyal, 286 U.S. 123, 127 (1932).

38. U.S. ConST. art. I, $\S 8$.

39. See, e.g., Abrams, supra note 35, at 1128.

A Tel Aviv attorney makes an interesting argument that copyright has its roots in ancient Jewish law, beginning with a verse in the Bible that says: "Therefore behold saith my Lord. I am against the prophets that steal my words everyone from his neighbur." Hazan, The Origins of Copyright Law in Ancient Jewish Law, 18 Bull. COPYRIGHT Soc'y 23, 24 (1969) (emphasis added by author). (1899).

40. A. BirRell, Seven Lectures on the LaW and History of Copyright in Books 42

41. Id. (describing the story as being "voted unworthy of belief").

42. 2 W. BLACKSTONE, supra note 30 , at $* 407$.

43. G. HeGel, PhILosophy of Right 51 (T.M. Knox trans. 1952).

44. Id. at 40-57. Hegel described a work of art as "peculiarly the property of the individual artist ...." Id. at 54.

45. 1. KANT, Of The Injustice in Counterfeiting Books, in 1 ESSAYS AND TREATISES ON Moral, Polttical, and Various Philosophical Subjects 225, $229-30$ (W. Richardson trans. 1798). Kant argued that an author "has an inalienable right (jus personalissimun) always to speak 
property ${ }^{46}$ is especially true when the property is a work of art. ${ }^{47}$ They argue that works of art are created through a person's mental labor and thus embody more of her individual essence of being than works created through routine physical labor. Since artistic works are part of an artist's very identity, she never should be completely separated from the work. The personhood theory of intellectual property thus supports not only the idea of copyright in artistic products, but also the idea of moral rights. ${ }^{48}$

The debate surrounding the correct theory about why intellectual property exists is not purely academic. It can play a decisive role in the outcome of copyright cases. For example, in Sony v. Universal City Stu$\operatorname{dios}^{49}$ (The Betamax Case), the Supreme Court held the videotaping of

himself through every other, that is nobody dares make the same speech to the public but in his [the author's] name." Id. at 238. Kant's work can be read as supporting the moral rights concepts of integrity and paternity. See infra notes 84-101 and accompanying text.

46. For an excellent discussion of the personhood theory of property, see generally Radin, Property and Personhood, 34 STAN. L. REv. 957 (1982) (personhood theory is premised on the belief that in order to achieve proper self-development, i.e., personhood, one must have some control over resources in her external environment). Radin's article discusses the personhood perspective as developed by Hegel, traces its development, and attempts to develop a contemporary view of the doctrine. She demonstrates, among other things, that the personhood theory provides a moral basis for protecting some sorts of property more than others. Id. at 978-91. She suggests that the right to entitlements should grow stronger the more closely property is connected with personhood. Id. at 986.

47. One commentator expresses this theory as follows: "When an artist creates . . . he does more than bring into the world a unique object having only exploitive possibilities; he projects into the world part of his personality and subjects it to the ravages of public use." Roeder, The Doctrine of Moral Right: A Study in the Law of Artists, Authors and Creators, 53 HARv. L. REv. 554, 557 (1940).

48. See infra note 87 and aecompanying text for a discussion of the relationship of the personhood theory to moral rights.

49. 464 U.S. 417 (1984). It is worth noting that the dissent in this case includes the rather strange bedfellows of Justices Marshall and Rehnquist-an indication of the degree to which the opinion raises issues not within traditional ideological boundaries.

The Betamax case has been widely discussed in the legal literature, see, e.g., Comment, Sony v. Universal City Studios: Can the Marketplace Relationship Between Creator and Consumer Be Preserved?, 62 DEN. U.L. REv. 873 (1985) (proposing royalty payments to copyright owner as means of equalizing marketplace relationship between creditor and consumer); Note, Educating Sony: Requiem for a "Fair Use," 22 CAL. W.L. REv. 159 (1985) (proposing compulsory licensing of educational materials and elimination of fair use defense); Note, Universal City Studios, Inc. v. Sony Corp.: "Fair Use" Looks Different on Videotape, 66 VA. L. REv. 1005 (1980) [hereinafter Note, "Fair Use" on Videotape] (proposing blanket exemptions for home video recording or compensatory royalty plan for producers); Note, The Betamax Case: Accomodating Public Access and Economic Incentive in Copyright Law, 31 STAN. L. REv. 243 (1979) (proposing damage remedy aimed at manufacturer and seller of videotapes); see also $3 \mathrm{M}$. NIMMER \& D. NIMMER, supra note 2, $\S 13.05[\mathrm{~F}][\mathrm{b}][\mathrm{i}]$; Cirace, supra note 9, at 667-81 (discussion of court of appeals decision); Fisher, supra note 9, at 1664-66, 1784-89; Gordon, supra note 9, at 1652-57; Sinclair, supra note 9, at 308-28. 
televised programs for purposes of "time-shifting"50 could be considered fair use. ${ }^{51}$ Laurence Tribe had argued in a inemorandum to the House Subcommittee on Videorecording that the noncommercial status of the use was not sufficient justification for a fair-use defense. He offered what he called a "simple analogy: jewel theft is not converted into a noncoinmercial veinahity if stolen jewels are simply worn rather than sold."52 Justice Stevens' majority opimion rejected this analogy, which was also used by the dissent to explain that the theft of physical property "1nay have commercial significance, for the thief deprives the owner of his right to sell that particular iteln to an individual. Time-shifting does not even reinoteily entail coinparable consequences to the copyright owner."53

The disagreeinent between Tribe and Justice Stevens was not just disagreeinent over a correct analogy-it goes back to the debate about the origin of intellectual property rights. If the "natural rights" theory is followed, then Tribe's analogy is compelling. The use to which stolen property is put is irrelevant; what inatters instead is that the holder is deprived of soinething that is rightfully his. But if the assunption that property rights in intellectual work exist only to provide incentive to the author is correct, then the Court's rejection of Tribe's analogy inay be well-taken. ${ }^{54}$ Similarly, a court's willingness to incorporate the concept of moral rights inay hinge on whether the judge accepts the "personality" theory of intellectual property.

50. Time-shifting is a practice whereby a viewer tapes a program when broadcast, watches it later and erases the videotape. The Betamax Case, 464 U.S. 417, 423 n.3 (1984). It is to be distmguished from "librarying," a practice whereby the viewer tapes a program with the intention of keeping it permanently. Id.

51. Id. at 421. More specifically, the Court considered whether the manufacturer of a videotape recorder could be guilty of contributory infringement for copyright violations. Plaintiffs had not sought damages against individual consumers. The Court initially recognized that the doctrine of contributory infringement states that if an instrument can be used for a substantially noninfringing purpose, then there is no contributory infringement liability. Id. at 434-42. The Court concluded that time-shifting is not copyright infringement. Id. at 443-55. On the subject of contributory infringement and copyright law, see Comment, Contributory Infringement By Providing the Means: The Staple Article of Commerce Doctrine and an Alternative Analysis for Copyright Law, 18 J. MARShall L. REv. 703 (1985) (concluding that courts should not incorporate staple article of commerce doctrine into copyright law, but should employ traditional contributory infringment analysis to make a prima facie determination as to whether contributory infringment exists).

52. Betamax Case, 464 U.S. at 450 n.33; see also Sinclair, supra note 9, at 324 n.318 (reference to Professor Tribe).

53. Id.

54. Sinclair also criticizes Tribe's analogy, stating that the "appropriate analog[y] is ... stopping and looking twice at the jewelery on the person wearing it." Sinclair, supra note 9, at 324 n.318. Regardless of the property rights theory involved, Sinclair's alteruative analogy is not correct. Viewers have not just "looked" at a television show; they have converted it into a physical fixation on videotape. 


\section{The Major Differences}

There are many different types of property, ranging from tangible "things" such as the baker's loaf of bread, the land his bakery occupies, and the bakery's furniture, to intangible assets such as the baker's "goodwill" in the business and possibly his employees' entitlements to continued employment. ${ }^{55}$ Obviously, all these types of property cannot and should not be treated the same way. Our concept of property has changed simce the Blackstonian model of absolute domain over a tangible "thing." 56 The generally accepted modern view is the Hohfeldian concept of property as a collection of rights that establish a legal relationship between the property holder and the world at large.57 Under the Hohfeldian model, intellectual property does resemble other forms of intangible property. However, there are several other aspects of intellectual property law that make it a unique form of intangible property. The next section of this Article will describe these differences.

1. "Fair Use." The single most significant difference between intellectual property and other forms of property is the fair use "defense." This doctrine, which has been described as the "most troublesome in copyright law," 58 has been defined as "a "privilege in others than the owner of a copyright to use the copyrighted material in a reasonable manner without his consent, notwithstanding the monopoly granted to the owner' [of the copyright]." 59 Obviously, this definition tells us very little about when this defense is available. ${ }^{60}$ It can be described broadly

55. See generally Reich, The New Property, 73 Yale L.J. 733 (1964) (describing "government largesse" as taking the place of traditional forms of wealth).

56. Blackstone defined property as "that sole and despotic dominion which one man claims and exercises over the external things in the world, in total exclusion of the right of any other individual in the universe." 2 W. BLACKSTONE, COMMENTARIES *2; cf. Vandevelde, supra note 25, at 330-33 (describing Blackstonian theory of property as containing two elements: (1) an "external thing" and (2) absolute dominion by the owner). Blackstone did, however, recognize intellectual property. See supra notes 30-31 and accompanying text.

57. See Hohfeld, supra note 25 , at $20-25$.

58. This quotation is from Judge Learned Hand's opinion in Deller v. Samuel Goldwyn, Inc., 104 F.2d 661, 662 (2d Cir. 1939). It is repeated in nearly every major treatise, casebook, or law review article on the subject of fair use. See, e.g., 3 M. NIMMER \& D. NIMMER, supra note 2, $\S 13.05$; Gordon, supra note 9, at 1600; Walker, supra note 9, at 735.

59. Rosemont Enters. v. Random House, Inc., 366 F.2d 303, 306 (2d Cir. 1966), cert. denied, 385 U.S. 1009 (1967).

60. Although I refer to the doctrine as a defense, a view shared by most commentators, others argue that defense is not the correct terminology. See generally Cohen, Fair Use in the Law of Copyright, CopYRIGHT LAW SyMPosium (ASCAP) 43, 45-58 (1955). In his treatise, Melville Nimmer notes a view taken by some courts that fair use constitutes "a mixed issue of law and fact." $3 \mathrm{M}$. NIMMER \& D. NimMER, supra note $2, \S 13.05$. The court in Rosemont Enters. refers to the doctrine as a "privilege." 366 F.2d at 304, 306-07. 
as a common law standard ${ }^{61}$ that permits use under circumstances in which the benefit to the public, or another artist, outweiglis the interest of the copyriglit lrolder. ${ }^{62}$ The classic situation cited (often incorrectly) as an example of fair use is the copying and distribution of materials for educational purposes.63 Section 107 of the Copyright Act codifies this common law concept:

Notwithstanding the provisions of section 106, the fair use of a copyrighted work ... for purposes such as criticism, comment, news reporting, teaching (including multiple copies for classroom use), scholarship, or research, is not an infringement of copyright. In determining whether the use made of a work in any particular case is a fair use the factors to be considered shall include-

(1) the purpose and character of the use, mcluding whether such use is of a commercial nature or is for nonprofit educational purposes;

(2) the nature of the copyrighted work;

(3) the amount and substantiality of the portion used in relation to the copyrighted work as a whole; and

(4) the effect of the use upon the potential market for or value of the copyrighted work. ${ }^{64}$

The first two factors of the Act focus on the benefit to the public that may result from reproduction of the copyrighted works, with an explicit assumption that noncommercial educational uses are of greater benefit than commercial uses. The last two factors focus on the harm done to the artist by the copying.

The fair use defense may seem unremarkable and logical when applied to intellectual property, but consider its extension to otlier types of property. Imagine a teaclier appropriating someone's van to take his children on a field trip (clearly an educational purpose), a collector removing just one gein from the crown jewels (a de minimis amount taken), ${ }^{65}$ or a person inhabiting without rent one of Donald Trump's

No one knows exactly what fair use is: A cartoon in Nimmer's casebook shows the classic guru, astride a mountain top, being asked by a seeker of truth: "What is fair use?" M. NIMMER, CASES AND MATERIALS ON Copyright 367 (3d ed. 1985).

61. For a discussion of the distinctions between standards and rules, see Kennedy, Form and Substance in Private Law Adjudication, 89 HARv. L. REv. 1685, 1687-1701 (1976); Schlag, Rules and Standards, 33 UCLA L. REv. 379, 381-83 (1985).

62. There are other theories of fair use-the suggestion has been made that fair use is predicated on the implied consent of the author. $3 \mathrm{M}$. NIMMER \& D. NiMMER, supra note $2, \S 13.05$. Michael Sinclair effectively repudiates this theory. Sinclair, supra note 9, at 275-76. For a general discussion of fair use theories, see Gordon, supra note 9, at 1602-22.

63. This is not to suggest that educators have an unlimited right to copy others' works. See infra note 145.

64. 17 U.S.C. $\$ 107$ (1988). For an examination of legislative history of this section of the copyright act, see Sinclair, supra note 9, at 294-98.

65. The idea that a de minimis copying may constitute fair use has existed for decades and was apparently endorsed by Justice Blackmun in the Betamax case. See Sinclair, supra note 9, at 276-77 
thousands of New York apartments (almost no economic effect on the market). These examples may seem frivolous or impractical, but they are completely consistent with the underlying assumptions behind the concept of "fair use." It is only because we are so conditioned to the traditional rules of private property ownership that we cannot seriously imagine a "fair use" of cars or housing. ${ }^{66}$ But if the principles behind the fair use defense (e.g., the interest of society in education is greater than the interests of the property holder) are valid, then they should apply with equal validity to other forms of property.

2. The Duration Limitation. Duration rules retain the copyright holder's interest in her work of art in the private splere for a limited time, then permanently transfer it to the public sphere ("the public domain"). ${ }^{67}$ Under the Copyright Act, a copyrighted interest is protected for the life of the artist, plus fifty years. ${ }^{68}$ If the work is pseudonymous, it is protected for seventy-five years from its publication or a hundred years from its year of creation, whichever period expires first. ${ }^{69}$ Most European countries, which are bound by the Berne Convention, an international copyright treaty, also have a fifty-year limitation..$^{70}$

During the early years of English copyright law, ${ }^{71}$ there was considerable debate about whether copyright protection should be perpetual or, if limited, what the proper time period for this limitation should be. ${ }^{72}$

(Blackmun gave examples of situations in which de minimis copying was appropriate, such as photocopying newspaper chippings or pinning quotations on a bulletin board.).

66. To a limited degree, adverse possession can be considered a "fair use" of property. However, it is much more difficult to establish adverse possession than it is to utilize a fair use defense, and the underlying justification for adverse possession is based on the rights of the individual adverse possessor, not of society in general.

67. 17 U.S.C. $\S 302$ (1988).

68. Id. $\S 302(a)$.

69. Id. $\S 302(\mathrm{c})$.

70. The Berne Convention, which first met on Septenber 9, 1886, created the International Union for the Protection of Literary and Artistic Works. Article 7, section 1 of the Berne Convention provides that the "term of protection granted by this Convention shall be the life of the author and fifty years after his death." Berne Convention for the Protection of Literary and Artistic Works, July 24, 1971. More than half the world's countries providing copyright protection have a 50 years after the death of the author rule; in others it is longer-80 years (in Columbia, Cuba, Panama, and Spain)-and others shorter-from life plus 15 years to life plus 40 years after the death of the author. Only Portugal provides perpetual copyright protection. Cohen, Duration, 24 UCLA L. REv. 1180, 1190 n.32 (1977).

In contrast to copyright law, many countries, including those that limit copyright duration, provide perpetual protection for moral rights. See infra notes 91-95 and accompanying text.

71. For a comprehensive discussion of the history of the duration rule in Anglo-American Law, see Cohen, supra note 70, at 1192-1210 (1977).

72. See E. Drone, A Treatise on the law of Property in Intellectual ProducTIONS IN GREAT BRITAIN AND THE UNITEd STATES 73-83 (1879). Macaulay was one of the most important opponents of extended periods of copyright duration. He argued, among other things, 
Today, however, in contrast to the extensive literature discussing "fair use," only a few law review articles have been devoted exclusively to the subject of duration, ${ }^{73}$ and the merits of the time limitation of copyright protection are virtually unquestioned. ${ }^{74}$ Nimmer asked the rhetorical question: "If I may own Blackacre in perpetuity, why not also Black Beauty?"75 $\mathrm{He}$ answered that the first amendment aspect of the public interest inandates the result: "[N]o countervailing speecl interest [must] be balanced against perpetual ownership of [other forms of property]." 76

Again, when viewed in a vacuun, the time himitation appears inevitable and unquestionable. But consider the words of a ninteentli century critic:

The law which puts an arbitrary terminus on the ownership of hiterary property is the same in principle with one that would abridge the farmer's right to his orchards and grainfields. If there were the reinotest danger that this principle would ever be applied to material possessions, every Enghish tongue would clamor for a new Magna Charta....

that the creativity of authors would not be enhanced by longer copyright protection. In a famous passage, he asked whether $\mathrm{Dr}$. Johnson would have increased his productivity if copyright protection was extended to 60 years: "Would it have stimulated his exertions? Would it have once drawn him out of his bed before noon? Would it have cheered him under a fit of spleen." 11 T. MACAULAY, The COMPlete Works of LoRd MACAulay 666 (1898) (AMS Press ed. 1980). Macaulay's example is certainly questionable: Dr. Johnson had no children and was a widower.

Macaulay does offer a stronger argument against lengthy or perpetual copyright protection: the probability that the author's work will be in the hands of his publisher, not his heirs. He gave the example of Milton's Paradise Lost, which at one time was in the hands of a single bookseller so that everyone wanting the work "must buy them at Tonson's shop and at Tonson's price." Id. at 670. In the meantime, Milton's granddaughter was starving and seeking charity. Id.

Additionally, he argues that an heir may choose to suppress works for non-monetary reasons, drawing on the example of Boswell's Life of Dr. Johnson. He stated that it was common knowledge that Boswell's oldest son considered his father's relationship to Johnson "a blot on the escutcheon of the family." Id. at 673. If the son had the rights to the book, Macaulay argued "[a]n unadulterated copy of the finest biographical work in the world would have been as scarce as the first edition of Camden's Britannica." Id.

73. See Cohen, supra note 70; Dubin, Copyright Duration, 53 IowA L. REv. 810 (1968). The lack of debate on the issue can be seen as further evidence that Anglo-American jurisprudence has rejected the natural law, fruit-of-the-creators-labor theory of intelleetual property.

74. Saul Cohen does give a brief, but reasonably thorough, examination of the desirability of limited copyright versus perpetual protection, Cohen, supra note 70, at 1182-85, but Nimmer gives it short shrift in his treatise, 2 M. NIMMER \& D. NIMMER, supra note 2, §9.01[A]. Cohen raises three basic arguments: (1) the "disembodied" nature of the property makes the task of tracing ownership difficult, particularly since different persons may own different rights; (2) the first amendment concern raised by Nimmer, see supra note 9; and (3) the language of the Constitution itself, which provides that Congress may protect works for "limited times," U.S. CoNST. art. I, § 8. Cohen, supra note 70 , at $1184-85$.

75. Nimmer, supra note 9, at 1193.

76. Id. This is a peculiarly American solution and one which is not totally consistent with Nimmer's own theory regarding first amendment and copyright. He argues in a later section of the same article that only news photographs deserve first amendment protection. Id. at 1198-1200. 
[T]o take from one and give to all is not less communism in the case of literary property than it is in any other kind of property. ${ }^{77}$

3. Moral Rights. Differences between intellectual property and other forms of property also can work to the artist's benefit. In at least sixty-three countries ${ }^{78}$ and in three states, New York, ${ }^{79}$ California, ${ }^{80}$ and Massachusetts, ${ }^{81}$ intellectual property law in the form of moral rights or droit moral gives an artist unque privileges. Once Blackacre is sold, it is beyond the owner's control forever. ${ }^{82}$ Under moral rights theory, however, Blue Boy ${ }^{83}$ cannot be changed to Green Boy at the whim of its new owner. ${ }^{84}$ The original creator of Blue Boy also may have the right to decide when the painting is to be exhibited, to compel identification of the painting as his work and even to completely forbid exhibition of the painting. ${ }^{85}$

Moral rights originated in France and initially were created by judges, not legislatures. ${ }^{86}$ These rights have their roots in the European philosophical concept that an artist's work is part of his personality and

77. E. Drone, supra note 72 , at 51.

78. See Comment, Copyright: Moral Right-A Proposal, 43 Fordham L. Rev. 793,797 (1975) (advocating federal legislation to provide uniform protection for the personal rights of an author). For a thorough discussion of moral rights in France, the country in which moral rights originated, see Da Silva, supra note 19, at 7-37; Sarraute, supra note 19, at 465-84.

79. N.Y. ARTS \& CuLT. AFF. LAw $\S \S 14.01-03$ (McKinney 1984 \& Supp. 1989).

80. CAL. Crv. CoDE $\S 987$ (West Supp. 1989).

81. MASS. ANN. LAWS ch. $231, \S 85 \mathrm{~S}$ (Law. Co-op. 1986).

82. This result assumes there are no restrictive real covenants or servitudes to the contrary. See generally J. DuKEMINIER \& J. KRIER, PROPERTY 959-1091 (1981).

83. The reference is to the famous painting of Sir Thomas Gainsborough (1727-1788). For a discussion of the painting's value, see G. REITLIHGER, 3 THE ECONOMICS OF TASTE 65 (1970).

84. This is an example of the artists' right to protect the integrity of her work to prevent distortion or dismemberment. For example, the French artist Bernard Buffet who had decorated a refrigerator with six panels of paintings was able to prevent the owner of the refrigerator from removing the panels for separate sale because Buffet considered the panels collectively as one painting. See Merryman, supra note 19 , at 1023 .

The idea of a buyer attempting to change the color of a work of art is not as far-fetched as it may seem. In 1958, the Airport Commission of the City of Pittsburgh received an original Alexander Calder mobile as a gift. It repainted the mobile, which was originally black and white, in the county's colors of green and gold. Calder claimed that the alteration violated his artistic integrity, but under federal and state law he was without remedy. See Gantz, supra note 19, at 873-74.

85. These are examples of the right of integrity, the right of paternity, and the right of withdrawal. For a thorough discussion of these rights, see Da Silva, supra note 19, at 7-37.

86. Da Silva gives an excellent summary of the history of the moral rights concept in Francc. Id. at 7-11. Since the doctrine did originate in France, American authors also discuss French law in detail and continue to refer to the moral rights by their French names. Da Silva divides the history of droit moral into three periods: from 1793 to 1878, from 1878 to 1902 , and from 1902 to 1957. Id. at 9. Although moral rights were first officially recognized by French courts and tribunals in the middle of the 19th century, Sarraute, supra note 19, at 465 , today the doctrine is codified by statute in France, with an opening sentence that reads: "The author of an intellectual work shall, by the mere fact of its creation, enjoy an exclusive incorporeal property right in the work, effective against 
therefore should not be destroyed or otherwise injured.87 In essence, they mean that the artist never really gives up her interest in the work of art to the subsequent property holder. In a direct conflict, the artist's moral rights limit the purchaser's property rights.

In France, the doctrine of moral rights recognizes four rights that are personal to the artist:

1. The right of disclosure (the "droit de divulgation")-an artist's right to decide when and if the work will be released to the public.

2. The right of retraction (the "droit de retrait ou de repentir")the right of an artist to withdraw or modify previously published or exhibited work.

3. The right of integrity (the "droit au respect de l'oeuvre")- the right to prevent the work froin being distorted or destroyed.

4. The right of attribution (the "droit de la paternite")- the artist's right to be recognized as the work's creator. 88

The Berne Convention, recognized by seventy-seven countries, including the Umited States, recognizes the inoral rights of paternity (synonymous with the attribution right) and a limited right of integrity ${ }^{89}$

all persons." Law of Mar. 11, 1957, No. 298 [1957] J.O. 2723, 4143 (France) (English translation), reprinted in 1 UNESCO, COPYRIGHT LAWS AND TREATIES OF THE WORLD (1980).

87. See supra notes $43-48$ and accompanying text.

88. In this Article I have chosen to use the categories identified by Da Silva, supra note 19, at 34. Merryman takes a slightly different approach, identifying three basic rights-integrity, paternity, and divulgation-and states that the "right to repent or to retake" is the "most important right." Merryman, supra note 19 , at 1028.

89. The Berne Convention specifically gives an author "the right to claim authorship of the work and to object to any distortion, mutilation, or other modification of, or other derogatory action in relation to, the said work, which would be prejudicial to his honor or reputation." Berne Convention, art. 6 (June 26, 1948), reprinted in 4 M. NIMMER \& D. NIMMER, supra note 2, at app. 27. These rights are available to the author even after he has transfered his economic rights to someone else. Id.

The fact that the United States has joined the Berne Convention will not necessarily mean more moral rights protection for the artist. Specifically, adherence to the Berne Convention, signed into law on October 31, 1988 by President Reagan, eliminates the Copyright Act's mandatory requirement of a visually perceptible and legally sufficient copyright notice for a work published after March 1, 1989. Strauss, Don't Be Burned By The Berne: A Guide to the Changes in the Copyright Laws as a Result of the Berne Convention Implementation Act of 1988, 71 J. PAT. OFF. Soc'y 374, 379 (1989). Registration under the Berne Convention becomes a two-tiered system excusing mandatory registration for foreign works while requiring protective registration for works of American origin. Id. at 381. The Berne Convention significantly doubles the amount of statutory damages rccoverable in actions for infringement of registered works, thereby encouraging the practice of voluntary copyright registration. Id. at 383. Congress specifically disclaimed any intent to expand or reduce the availability under U.S. or state law of an author's "moral rights." Goldberg \& Bernstein, Berne, Baby, Bernel, N.Y.L.J., Nov. 18, 1988, at 3, cols. 1, 4. In fact, on the issue of "moral rights," Congress, in section 2 of the Berne Implementation Amendments, declared that the Berne Convention is " 'not self-executing under the Constitution and laws of the United States," " the " "obligations of the United States under the Berne Convention may be performed only pursuant to appropriate domestic law," "and that the amendments, " "together with the law as it exists on the date of the enactment of this Act, satisfy the obligations of the United States in adherence to the Berne Conven- 
Although in France and several other countries, moral rights are perpetual and inalienable, ${ }^{90}$ under the Berne Convention they expire with the end of copyright protection. ${ }^{91}$

In the Umited States, the California Art Preservation Act prohibits "pliysical defacement, mutilation, alteration, or destruction of a work of fine art" by any person other than the artist. ${ }^{92}$ The Massachusetts statute, like the California Act, protects "fine art" from "physical alteration or destruction."93 The New York Artists' Authorship Riglits Act guarantees the right of paternity and similarly prohibits display of an "altered, defaced, mutilated or modified form" of the artist's work..$^{94}$ All of

tion and no further rights or interests shall be recognized or created for that purpose." "Id. For an extensive discussion of the possible impact of the Berne Convention on moral rights protection, see Ginsburg \& Kernochan, One Hundred and Two Years Later: The U.S. Joins the Berne Convention, 13 COLUM. J.L. \& ARTS 1 (1988).

90. French law states that in addition to being malienable and perpetual, moral rights are also "imprescriptable." Law of Mar. 11, 1957, art. 6. Even works created for hire trigger moral rights protection for the artist, not the artist's employer. Da Silva, supra note 19, at 12. For a discussion of the problems of the French concept, see id. at 12-17. In Germany, by contrast, moral rights expire 70 years after the author's death. Id. at 11.

91. The Berne Convention ties the duration of moral rights to the duration of copyright in the copyright holder's country, stating that they shall last "at least until the expiring of economic rights ..." However, it states further that countries whose legislation at the time of ratification of the Act does not provide for moral rights after death inay provide for the expiration of these rights. Berne Convention, June 26, 1948, art. 6, reprinted in 4 M. NIMMER \& D. NiMMER, supra note 2, at app. 27.

92. CAL. Crv. CoDE $\$ 987$ (West. Supp. 1990). The California Act incorporates the rights of integrity and paternity, but its protection is limited to paintings, sculptures, drawings, and works in glass. Id. $\S 987(\mathrm{~b})(2)$, (c). Moreover, this work must be of "recognized quality," which will be determined by the "opinions of artists, art dealers, collectors of fine art, curators of art museums, and other persons involved with the creation or marketing of fine art." Id. $\S 987(b)(2)$, (f). The Act excludes "works for hire" from protection. Id. § 987(b)(2). Additionally, artists are allowed to waive their rights under the Act. Id. $\$ 987(\mathrm{~g})(3)$. For a discussion of the California Act, see generally Gantz, supra note 19.

93. MAss. ANN. LAws ch. $231, \S 85 \mathrm{~S}$ (Law. Co-op. Supp. 1989). Like the California Act, the Massachusetts Act protects the rights of paternity and integrity. Its primary difference is that it provides protection for a much broader class of works. The Act states that works of "fine art" include, but are not linited to: "any painting, print, drawing, sculpture, craft object, photograph, audio or video tape, film, hologram, or a combination thereof, of recognized quality." Id. § $85 \mathrm{~S}$ (b). It also provides for expert opinions to determine what is "fine art." Id. $\$ 85 \mathrm{~S}(\mathrm{f})$. For a discussion of the Act, see Koven, Observations on the Massachusetts Art Preservation Act, 71 Mass. L. REv. 101, 104-08 (1986); see also You Can't Chop an Artwork Up in Massachusetts, ART NEws, Apr. 1985, at 21. For a comparison and criticism of the California and Massachusetts Acts, see Note, Artists' Rights in the United States: Toward Federal Legislation, 25 HARV. J. ON LEGIs. 153, 184-88, $191-93$ (1988).

94. N.Y. ARTs \& CulT. AfF. LAw §§ 11.01, 14.03(1) (McKinney Supp. 1987). The Act is viewed primarily as protecting the author's right of paternity, since it only protects works that have been publically displayed from alteration or mutilation, $i d$. $\S 14.03(3)(\mathrm{e})$, and only when damage to the author's reputation is at stake. Id. \$14.03(1). For a comparison of California and New York laws, see Damich, supra note 19. 
these acts exclude any type of literary works. ${ }^{95}$ In the rest of the United States, artists wishing to protect their interests inust resort, usually unsuccessfully, ${ }^{96}$ to theories of unfair competition, ${ }^{97}$ contract law, ${ }^{98}$ defa-

95. There may be several reasons why literary works are excluded from these acts. For one thing, the physical damage to a work of art is easier to determine than possible intangible damage to a literary work. Additionally, the powerful publishing, motion picture, and broadcasting industries oppose extending moral rights beyond artwork. See Note, supra note 93, at 207 (discussing proposed federal legislation, infra note 101 , but its statement regarding opposition by these industries applies to state laws as well). Finally, a student commentator suggests that there may be first amendment problems if moral rights are extended to plays and novels. Note, supra note 93, at 207-08.

96. A number of comnentators have discussed at length the attempts to use alternative legal theories to provide moral rights protection, and the majority have concluded that these causes of action provide insufficient protection for the artist. Merryinan, for example, characterizes attempts to use tort law to protect inoral rights as "feeble." Merryman, supra note 19, at 1049; see also Gantz, supra note 19; Sarraute, supra note 19; Note, An Artist's Personal Rights in His Creative Works: Beyond the Human Cannonball and the Flying Circus, 9 PAC. L.J. 855, 867-80 (1978) (concluding that courts do not adequately protect author's personal right of credit); Note, supra note 93 , at 164-73. But see Treece, supra note 19, at $494-95$ (development of a coinmon law paternity right perhaps possible via tort law, but the more promising alternative lies with contract law).

97. Most coinmentators believe the best avenue for protecting moral rights today is the Federal Tradeinark (Lanham) Act, ch. 79-540, § 43(a), 60 Stat. 427, 441 (1946) (codified at 15 U.S.C. $\S 1125$ (a) (1982)), which prevents unfair competition and has been used to protect the right of paternity. See, e.g.. Sinith v. Montoro, 648 F.2d 602, 606-07 (9th Cir. 1981) (removal of actor's name froin film credits and the substitution of another's name found to fall under the prohibition agaimst "passing off" of goods set forth in the Lanham Act); Gilliam v. American Broadcasting Co., 538 F.2d 14, 24 (2d Cir. 1976) ("It is sufficient to violate the Act that a representation of a product ... creates a false impression of the product's origin."). Confirmation of the Federal Trademark Act's scope arguably can be drawn from the recent comment by the director of the World Intellectual Property Organization that it was not necessary for the United States to enact a moral rights law to comply with Berne Convention requirements. Guinn, Berne Implementation Act Confronts Some Key Issues, N.Y.L.J., Dec. 2, 1988, at 5, col. 1. David E. Guinn states in that article that the director's "finding" may have in fact created moral rights protection under the Copyright Act. Id. In recent times, a variety of moral-rights type laws and protections have passed in state legislatures and exist by virtue of federal legislation, in particular the Lanham Act, and at common law. Id. at 5-6. This development in state copyright laws represents a contradiction with section 301 of the Copyright Act, which Guinn says preempts " "all legal or equitable rights that are equivalent to any of the exclusive rights' " governed by the Copyright Act. Id. at 6. Many courts have held that state unfair coinpetition actions and torts involving conversion and tortious interference with contract are preempted because they involve the same fundamental elements. See, e.g., Harper \& Row, Publications v. Nation Enters., 723 F.2d 195 (2d Cir. 1983), rev'd, 471 U.S. 539 (1985); Motown Record Corp. v. George A. Horniel \& Co., 657 F. Supp. 1236 (C.D. Cal. 1987). Although state artists' rights laws under the 1909 Act have been sustained on an appellate level, see, e.g., Morseburg v. Baylon, 621 F.2d 972 (9th Cir.), cert. denied, 449 U.S. 983 (1980) (upholding California's Resale Royalties Act under the prior copyright act, but reserving judgment as to the issue of preemption under the $1976 \mathrm{Act}$ ), there are no decisions on point holding that they are not preenpted under the 1976 Act. Guinn, supra, at 6.

98. See, e.g., Vargas v. Esquire, 164 F.2d 522 (7th Cir. 1947) (unsuccessful attempt by author to recover use of his name). 
Ination and libel,99 and invasion of privacy. ${ }^{100}$ Recently, federal legislation has been introduced that would recognize limited moral rights in works of fine art, although not in literary works. ${ }^{101}$

99. See, e.g., Seroff v. Simon \& Schuster, 6 Misc. 2d 383, 162 N.Y.S.2d 770 (N.Y. Sup. Ct. 1957), aff'd, 12 A.D.2d 475, 210 N.Y.S.2d 479 (1960) (author denied libel damages due to distorted translation of his book).

100. See, e.g., Geisel v. Poynter Prods., Inc., 295 F. Supp. 331 (S.D.N.Y. 1968) (no right of privacy claim to name Dr. Seuss).

101. For a detailed description of the bills' provisions and an argument that the moral rights protection is necessary, see generally Note, supra note 93.

The Visual Artists Rights Act of 1987 was introduced on August 6, 1987, as a proposed amendment to the present Copyright Act. S. 1619, 100th Cong., 1st Sess., 133 CoNG. Rec. S11,471 (Aug. 6 , 1987). In 1988, both the House and Senate approved in committee separate versions of the amendments (H.R. 3221, S. 1619), but the bill was never put to a full floor vote prior to adjournment. Had it been enacted, the proposal would have amended the copyright law to incorporate certain moral rights for pictorial, graphic, or sculptural works of "reeognized stature." See Note, supra note 93, at 184. The proposed act is intended to "secure the rights of authors of pictorial, graphic, or sculptural works to prevent the distortion, mutilation, or other alteration of such works, to provide for resale royalties." S. 1619, supra, at 1. It provides a definition of fine art as a "pictorial, graphic, or sculptural work of recognized stature" and states that "[i]n determining whether a work is of recognized stature, a court or other trier of fact may take into account the opinions of artists, art dealers, collectors of fine art, curators of art museums, restorers and conservators of fine art and other persons involved with the creation, appreciation, history or marketing of fine art." Id. at 2. Additionally the Visual Artists Rights Act proposed to create a fine arts adjunct to the Copyright Office that would be essentially a fine arts agency, a development that would require the government to develop a definition of "work of fine art" to be applied to all works submitted for resale royalty registration. Siegel, The Resale Royalty Provisions of the Visual Artists Rights Act: Their History and Theory, 93 D1CK. L.R. 1, 21 (1988). The potential effects of governmental definition of a "work of fine art" are far reaching. Id. at 15.

The original artist, whether or not she is the copyright holder, shall have the right to assert infringement of this seetion. Additionally, the artist would receive a royalty (seven per cent of difference of the seller's purchase price and the amount the seller receives for the work), each time the work is sold. This royalty right cannot be waived. S. 1619, supra, at 1 .

For a criticism of this legislation, see Palmer, Artists Don't Deserve Special Rights, Wall St. J., Mar. 8, 1988, at 34, col. 3. This column, written by the director of the Intellectual Property Project of the Competitive Enterprise Institute, contends that it is a "serious philosophical mistake" to claim a work of art is an extension of its creator. He argues this theory "confuses two dependencies: the dependence of the work on the artist for its creation and the dependence of the work on the audience for its continued existence." Id. at 34, col. 3 . He claims the fact that the work of art does not die with its creator refutes the personality theory. These statements illustrate a complete misunderstanding of the personality theory of property. Palmer confuses the impact of the work itself with the impact on the artist. It is true that once created, a work does not depend on the artist, but nevertheless it remains an integral part of the artist's personality. Palmer also criticizes the droit de suite section of the act. See infra notes 102-11 and accompanying text.

Fisher also appears to reject moral rights analysis in a footnote, stating that it is not "essential to either the idea of creativity or the larger conception of meaningful work . . . that the fruits of creative labor should remain unaltered forever." Fisher, supra note 9, at 1773 n.494. He compares an artist's work to that of an architect, cabinetmaker and chef, claiming that their artistry is not impaired because their products can be destroyed or altered. Id. Fisher's analogy ignores the unique bond between the artist and her work and the expectations of the creator of property. A chef understands that her work will be eaten; architects and cabinetmakers, although similar to artists, know that their work will be lived in and used for storage and must necessarily undergo alterations. 
Fine artists also receive a privilege not granted to other property holders in the form of laws recognizing the concept of droit de suite, 102 which literally means "follow-up right." 103 The droit de suite allows the artist to receive a share in proceeds realized from the subsequent resale of her works. This right, which is more accurately classified as a pecuniary right than a moral right, ${ }^{104}$ is recognized in various forms in France, ${ }^{105}$ Italy, ${ }^{106}$ Germany, ${ }^{107}$ and other countries ${ }^{108}$ and, in California, in the form of the California Resale Royalties Act. ${ }^{109}$ The California Act provides that whenever a work of fine art is sold, the seller shall pay the artist five percent of the sale. ${ }^{110}$ This right is non-waivable, unless the artist signs a written contract providing for an amount in excess of five percent of the sale. ${ }^{111}$

\section{Rationales for the Differences}

1. The Nature of the Property. I have explained the theories behind the existence of intellectual property and the differences between the protection afforded copyrighted works and other types of property. In this section, I will discuss the possible reasons for these differences. The obvious startimg point is the nature of most copyrighted materials.

One striking difference between intellectual property and most other fornis of property is the fact that the majority of works of art, once produced, can be reproduced an infinite number of times at little cost. ${ }^{112}$ Arguably, therefore, the harm to the copyright holder, when her work is "stolen" through reproduction, is not as great as the harnt to other property owners. If I steal your car, then I have stolen all your investment in the car, and you are without transportation. But if I steal your artistic

102. See generally Schulder, Arts Proceeds Act: A Study of the Droit de Suite and a Proposed Enactment for the United States, 61 Nw. U.L. REV. 19 (1966).

103. Id. at $22 \mathrm{n.13.}$

104. Id. at 22 n. 15 .

105. Id. at $22 \mathrm{n} .13$.

106. Id.

107. Id.

108. Katz, Copyright Preemption Under the Copyright Act of 1976: The Case of Droit de Suite, 47 GEO. WASH. L. REV. 200,203 n.22 (1978).

109. CAL. Civ. CoDE $\$ 986$ (West Supp. 1977).

110. Id. $\S 986(\mathrm{a})$.

111. Id. The question as to whether California's law is preempted by the 1976 Copyright Act has been much discussed, see, e.g., Katz, supra note 108, at 202-10 (discusses recent Supreme Court copyright decisions relating to preemption). However, a preemption challenge to the Act was rejected in Morseburg v. Balyon, 621 F.2d 972 (9th Cir.), cert. denied, 449 U.S. 983 (1980).

112. This statement does not apply to every work of art-for example, very large sculptures or murals may be virtually impossible to reproduce. Monroe Price notes that there is a trend toward works of a "monumental scale"-for example, a sculpture entitled "Smoke" that was 22 feet high and reached almost 50 feet in length. Price, supra note 19, at 1341. 
expression by copying your novel, then you have not lost either the original of the novel itself or the right to charge others for the right to copy. ${ }^{113}$

Another feature of intellectual property is the fact that it is difficult to prevent unauthorized uses-it is inuch easier to copy a book than to steal a car. ${ }^{114}$ This fact creates a concern economists call the "free rider" problem. They argue that when a good can be used easily by people who have not paid for it, these people will becoine "free riders" at the expense of those who did pay for the good. ${ }^{115}$

These two characteristics, (1) low, or less than cost, reproduction costs and (2) the danger of free riders, lead economists to categorize intellectual property as a "public good." 116 John Cirace, who has analyzed the economic aspects of copyright law, describes public goods as "those whose consunption by imdividual $\mathrm{A}$ does not preclude consumption by B, C, D, and others," in contrast to private goods, which when consumed by A cannot be consuined by B. 117 Economists acknowledge that the traditional market mechanisin, in which a buyer negotiates with a seller, does not always work for public goods because the free rider problem prevents the seller from receiving proper compensation. The classic example of a public good is national defense. ${ }^{118}$ A voluntary system where all citizens of a country contracted separately with inakers of arms obviously would be unworkable. Even if citizens grouped together to provide for a national defense system, there still would be others choosing not to pay for the system who nevertheless would enjoy its benefits. Therefore, economists concede that centralized purchasing and uniform taxation to pay for public goods are often necessary. ${ }^{119}$ An alternative method of disseminating public goods is to grant the purveyor of a public good a monopoly-as copyright law supposedly does. ${ }^{120}$

113. From a different perspective, the loss of the car can be considered less serious than the reproduction of the novel. The car is essentially fungible-if you are covered by insurance, then it can be easily replaced. The novel, on the other hand, is unique.

114. Most public copying machines carry explicit warnings regarding copyright infringement and many copy shops have a policy against copying entire books or any type of textbook. Such warnings and policies are usually ineffectual. I suspect the signs on copying machines have about the same impact as the "Do Not Remove" warning on mattress tags.

115. For a discussion of the free rider problem, see generally Gordon, supra note 9, at 1611 .

116. For a complete analysis of the "public good" characteristics of intellectual property, see Cirace, supra note 9, at 656-58. See also Demsetz, The Private Production of Public Goods, 13 J. LAW \& ECON. 293, 306 (1970).

117. Cirace, supra note 9 , at 657 .

118. See id. at 657; Gordon, supra note 9, at 1611.

119. See, e.g., Cirace, supra note 9, at 656-82; Gordon, supra note 9, at 1611.

120. Cirace, supra note 9 , at 657 . The use of the term "monopoly" is questionable. A classic monopoly system is a public utility system. Persons who wish to have electricity in any form must 
The "public good" characteristics of intellectual property have been used to justify a fair use defense. ${ }^{121}$ Economists argue that a product's price should equal the cost of producing additional units. If the price is greater than its inarginal cost, then there will be less than the "socially optimal" amount of the product consumed. ${ }^{122}$ The fair use defense thus is necessary to cure this form of market failure. It is argued that the fourth fair use factor that considers "the effect of the use upon the potential market for the value of the copyrighted work" 123 sufficiently protects the artist against harm to her market. ${ }^{124}$ However, this statement is only true if the factor is applied properly to consider aggregate harm. ${ }^{125} \mathrm{But}$ if a judge only considers the effect of one individual defendant's use, the test is virtually useless because the effect will almost always be minimal. ${ }^{126}$

utilize the utility's services. Copyright does give a novelist complete control over his novel, but not over all novels. A reader wanting to buy a book is not prohibited from purchasing other novels.

121. Cirace, supra note 9 , at 658 .

122. Id.

123. 17 U.S.C. $107(4)$ (1988).

124. Raskind, supra note 9, at 626. Raskind proposes a market model system, based on the fourth fair use factor. Fisher provides a sophisticated example of how a detailed look at the relevant market would work. See Fisher, supra note 9, at 1698-1744. Cirace makes an additional argument: Copying by an "individual" must be distinguished from copying by a "firm," which should never be considered fair use. See Cirace, supra note 9, at 682. Cirace certainly is correct in his contention that copying by a firm will present a greater harm to the market than will individual copying. But the inquiry should not stop there. The critical question is whether the copying is necessary to serve community interests, see infra notes $236-58$ and accompanying text, an inquiry Cirace omits.

125. Nimmer makes this point in his casebook following a case with the ultimate sympathetic defendant-a school teacher and choir director who used a copyrighted arrangement of a song for his choral music. See Wihtol v. Crow, 309 F.2d 777 (8th Cir. 1962). In discussing the decision that rejected the teacher's fair use defense, Nimmer asks, "What would happen to the market for "My God and I' if every school teacher in every school throughout the nation were permitted to make copies of the song each for his own students." M. N1MMER, supra note 62, at 390.

126. A classic example of a court's failure to consider the aggregate harm of copying occurred in Williams \& Wilkins Co. v. United States, 172 U.S.P.Q. (BNA) 670 (Ct. Cl. 1972), rev'd, 487 F.2d 1345 (Ct. Cl. 1973), aff'd per curiam by an equally divided court, 420 U.S. 376 (1975).

Two government libraries, the National Institutes of Health (NIH) technical library and the National Library of Medicine (NLM), subscribed to a large number of medical journals. The NIH library routinely answered requests from the NIH research staff for copies of articles from the journals, 487 F.2d at 1347-48, and the NLM participated in an interlibrary loan program, in which it supplied copies of articles fewer than 50 pages to other libraries, government agencies, and private and commercial organizations, including drug companies. In 1968, the NLM library received about 127,000 requests for interlibrary loans. Id. at 1348-49. Neither library monitored the reasons for requests for copies or the uses to which the copies were made. Id. The plaintiff was a publisher of 37 medical journals, who alleged injury to four specific journals in the suit. Subscription prices ranged from $\$ 12$ to $\$ 44$ per year, with the number of subscriptions ranging from about 3,100 to about 7,000. Most of plaintifi's revenue generated by these journals came from subscription sales. Id. at 1347 .

The Court of Claims, in a divided opinion, found that the defendant libraries' practice of copying the work was fair use. Id. at 1353 . The majority opinion began by emphasizing that both libraries were nonprofit institutions which in no way profited from the photocopying. It argued that 
More importantly, the fundamental flaw with a theory that relies exclusively on the public good characteristics of intellectual property to justify the fair use defense is that it does not offer any explanation why the defense is desirable in the first place. Just because it is sometimes possible to use soineone's property without substantially injuring the owner is not a justification for appropriating the property, unless there is a good reason for the appropriation. The argument that a "socially optimal" amount of goods will not be produced without fair use is meaningless without a reason why widespread distribution of intellectual property is desirable. ${ }^{127}$ The free rider problem, which may have been the real explanation behind the Supreme Court's conclusion that home videotaping of television programs is fair use, ${ }^{128}$ also does not offer a

the facts showed both libraries did enforce strict limitations to keep copying from being excessive. Id. at 1354. After these initial findings, the majority reached the heart of its opinion: Its determination that "medical science would be seriously hurt if such library photocopying were stopped," id. at 1356, and its conclusion that plaintiff had failed to prove any actual economic detriment due to the libraries' practice, $i d$. at 1357-58. The majority emphasized the "interrelated aspects" of its holding-its conclusion that fair use existed was not based on any one factor, but on the combination of factors present in the factual situation of the case. Id. at 1362-63.

The opinion, which a dissenting judge characterized as the "Dred Scott decision of copyright law," id. at 1387 (Nichols, J., dissenting), has been widely criticized from a variety of angles. Although the judge presumably was using Dred Scott as a symbol of a particularly bad decision, his analogy is fiawed in several respects. Aside from the inappropriateness of comparing a decision on slavery to one on copyright law, his comparison is inaccurate. After all, Dred Scott, viewed from the majority viewpoint, did protect the rights of property holders. Judge Nichols' concern in Williams was the failure of the majority to protect copyright holders' property rights. Id. at 1388. See, e.g., Cirace, supra note 9, at 658-67 (economic analysis criticism); Freid, Fair Use and the New Act, 22 N.Y.L. SCH. L. REv. 497, 509 (1977) ("the Court failed to properly address the question of the economic harm to the copyright holder"); Nimmer, Photocopying and Record Piracy: Of Dred Scott and Alice in Wonderland, 22 UCLA L. REv. 1052 (1975) (traditional common law criticism); Raskind, supra note 9, at 616 (primarily economic criticism). Even the Court of Appeals for the Ninth Circuit criticized the opinion as creating "doctrinal confusion." Universal City Studios v. Sony Corp. of Am., 659 F.2d 963, 971 (9th Cir. 1981), rev'd on other grounds, 464 U.S. 417 (1984).

Gordon, on the other hand, suggests that the Williams \& Wilkins Court properly used an economic analysis. However, her exteuded discussion of the case criticizes many aspects of the opinion. Gordon, supra note 9, at 1646-52.

Nimmer argued that: "[The critical question the court should have addressed] is not whether the particular photocopying activities of the defendant resulted in damages to the plaintiff, but rather whether wholesale photocopying of plaintiff's journals by any and all libraries and similar institutions would decimate the plaintiff's potential market." Nimmer supra, at 1054. He concluded the answer "must surely be in the affirmative," but if all libraries and schools could satisfy demand through photocopies, then "the market for educational and scientific materials would be almost completely obliterated," and the "source of new works to be copies would dry up." Id. Nimmer made this argument in 1975; subsequent events have cast doubt on its validity. Far from disappearing, the market for educational publications has increased in the last ten years.

127. Economists who make this argument engage in the type of circular thinking described in Cohen: A socially optimal amount of goods must be produced, because maximum production is socially optimal. Cohen, supra note 23 , at $820-21$.

128. Universal City Studios v. Sony Corp. of Am., 464 U.S. 417, 456 (1984). The Court's opinion more narrowly concluded that the manufacture of machines used for time-shifting videotaping 
valid justification for the defense. As the example of national defense illustrates, it is possible to enforce copyright laws through methods other than direct compensation to the holder by the user, such as a royalty tax on copying devices. ${ }^{129}$ People may object to these solutions as unnecessarily involving government $\mathrm{i}$ what should be a private transaction, or as too cumbersolne or expensive. These objections may or may not be valid, but they only explain why it is not desirable for the government to pre-

did not constitute contributory infringement. See supra notes $50-55$ and accompanying text. One of the arguments made against regulation of home videotaping was that it would be impossible to police home users of videotape machines. 464 U.S. at $471 \mathrm{n} .22$; see also 3 M. NIMMER \& D. NIMMER, supra note $2, \S 13.05[\mathrm{~F}][5][\mathrm{b}][\mathrm{i}], 13-123$ to -124 (raising concerns of privacy if individual citizen is liable). This policing problem is a particularly relevant argument, since although an average citizen would probably never steal a videotape or a movie from a video rental store, he may have no qualms about taping the same movie on his home recorder. To most people, videotaping simply does not feel like theft.

129. This proposal has been offered with respect to home videotaping. See, e.g., 3 M. N1MMER \& D. NiMmER, supra note 2, at 13-123 to -124 (arguing in favor of a compulsory license, with a royalty to be paid by the manufacturers of video recording equipment); Note, "Fair Use" on Videotape, supra note 49, at 1025-26 (proposing alternative compulsory royalty plans to compensate producers). Sinclair argues against the idea of royalties on videorecorders based on the Betamax case. However, he does approve of the idea of taxing tapes directly if more than six tapes are sold, on the assumption that excess tapes would be used for librarying. Sinclair, supra note 9, at 329-30. This approach does not take into account the increasing number of owners of video cameras who use multiple tapes to show their own home movies, a problem Sinclair acknowledges. Id. at 330 n.353. However, it might be possible to accommodate their needs by providing a rebate upon proof of ownership of a video camera.

The problem of educational photocopying also raises fair use and "frec rider" problems. See infra note 145. Professor Nimmer has proposed that a court or legislature could impose a mandatory hicense on copy centers, which would require the center to pay a fec to publishers for all copying done on its premises. $3 \mathrm{M}$. NIMMER \& D. NIMMER, supra note $2, \S 13.05[\mathrm{E}][4]$, at 13-112 to -113. The Williams \& Wilkins Court declined to impose this sort of remedy, stating it is up to the legislature, not the court, to create alternative solutions. Id. An excellent student note suggests a comprehensive model. Note, Blanket Licensing: A Proposal for the Protection and Encouragement of Artistic Endeavor, 83 Colum. L. REv. 1245 (1983); see also G. G1PE, NEARER TO THE DUST 263-76 (1967) (proposing a licensing system for making copies of copyrighted material, the establishment of a royalty clearinghouse facility, and the acceptance of the Norton Goodwin Amendment).

Another alternative is a central clearinghouse system for libraries. Libraries would pay a flat fee to a ccntral clearinghouse to receive licensed materials, each of which would carry an authorization number. Every time the licensed work was copied, the authorization number would be recorded. The licensees would receive payment from the clearinghouse, based on a rough percentage of use. Any library subscribing to the journals also would pay a licensing fee, which would allow it or its patrons to make unlimited copies of the journals. Additionally, universities and colleges could pay flat fees to give their professors unlimited use of all licensed materials for classroom distribution.

At present, the clearinghouse conccpt is in existence in a limited form in the nonprofit Copyright Clearance Center established in 1977. See Leibowitz, Copyright Law, Photocopying and Price Discrimination, 8 RES. L. \& ECON. 181, 194-97 (1986). The Center is currently not used widely; only 335 publishers are enrolled in the system, and it has only 923 user organizations. See id. at 195 . The Clearinghouse has been criticized by an economist, who concludes that price discrimination by the publishers will producc more efficient results. See id. However, it is too early to state definitely whether the clearinghouse concept, if followed by a larger number of libraries and educators, would be workable. 
vent the free rider problem, not why it is desirable for the government to encourage free riders through the fair use defense.

Neither of the two public good characteristics of intellectual property provide logical support for the duration limitation on copyright, but a different characteristic might provide a partial justification for the rule. Many copyrighted works last forever-when the paper on which the baker's son's poem is written has faded, copies of the words still may exist if the poem is good enough. ${ }^{130}$ The very best works of art continue to be valuable to the owner and his heirs for an unlimited period; indeed, they even may increase dramatically in value over time. ${ }^{131}$ Very few other types of property, except land ${ }^{132}$ and intangible monetary assets such as savings accounts and stocks, ${ }^{133}$ share this characteristic. Therefore, it might seem unfair to let the copyright holder and his heirs own a type of perpetual gold mine that other property holders do not have. The idea that fairness and equality are the operative criteria in allotments of property is novel, to say the least, but even if these criteria were used as the sole justification for the duration linitation, then it is difficult to explain why they do not apply to other forms of permanent property such as stocks or land.

A final characteristic of intellectual property that often is used to justify both the fair use defense and the duration rules, has to do with the content of the property. Many copyrighted works are works of art,

130. W.H. Audeu describes the perpetual nature of literary works:

Time that is intolerant

Of the brave and innocent,

And indifferent in a week

To a beautiful physique

Worships language and forgives

Everyone by whom it lives;

Pardons cowardice, conceit,

Lays its honors at their feet.

W.H. Auden, In Memory of W.B. Yeats, in Modern American Poetry \& Modern British POETRY 623, 624 (L. Untermeyer ed.1955). It is noteworthy that Auden himself chose to remove these verses from the complete version of the poems in his own later edition of his collected works. W.H. Auden, In Memory of W.B. Yeats, in Collected ShORTER PoEMs 141, 142-43 (1966). This is an example of an artist choosing to withdraw his work from the public. See infra note 268 and accompanying text.

131. There are innumerable examples of this phenomenon with respect to works of fine art. For example, Manet's painting, "Veiled Women," sold for 240 francs (\$154) in 1884; in 1965 it sold for 20,000 pounds $(\$ 56,000)$. F. DURET-RoBERT, Prices, in IMPRESSIONISM 304 (Réalités eds. 1973). Many authors also are unpopular in their tine, but attain popularity after their death. Edgar Allan Poe was paid $\$ 10$ for the Tell-Tale Heart, now considered a classic short story. E.A. POE, CoMPLETE STORIES AND PoEMS OF EdGar ALIAN POE 817 (1966).

132. Even land is not as indestructible as intangible assets like words; it can be submerged in water or destroyed by an earthquake.

133. However, even these assets are subject to inflation and other vagaries of political and economic changes that may affect value. 
which enrich our world in a variety of ways and are used by other artists as inspiration for their own original works. ${ }^{134}$ Other copyrighted works inay be educational or contain political information that is critical in helping citizens inake informed political decisions. Therefore, it is stated that these works are fundainental to the very foundation of our society and must be made freely available to those who cannot afford thein.

This argument should fall apart of its own weight when applied in the context of our free enterprise systein of private property. The proposition that valuable commodities should be distributed to all members of society for free if necessary inay or may not be appealing depending on your political perspective. But if you believe that any type of property that is critical to society should be available to all, then the need to have special rules for intellectual property disappears. If you do not believe that life-sustaining commodities-food, housing and clothing-should be provided for free if necessary, then you will be hard put to explain why intellectual property is so inuch more valuable than those other commodities as to justify an exception to inarketplace rules.

At this point, an alert defender of the copyright status quo may charge that my arguinent is simplistic. She would contend that it is the combination of the fact that inany copyrighted works are valuable to society and the fact that they are public goods that justifies fair use and duration limitations. Each factor standing alone does not explain the differences in intellectual property and other types of property, but together they justify special limmtations on copyrighted works. The baker's bread is important to society, it is true, but it is not a public good and the baker would be seriously burdened if his property rights in his bread were not absolute. This heavy cost outweighs any countervailing benefits to society. Fair use, on the other hand, represents only a slight burden to the copyright liolder because of her property's public good characteristics, and therefore the benefits to society outweigh this minor cost.

I would reply that this arguinent is also simplistic-the baker inay not be harmed by a ininimal appropriation of his "private goods," and the fair use defense, applied without consideration of aggregate market effects, can destroy a copyright holder's inarket. Moreover, if the status quo defender is right in asserting that when a public good is valuable to society it must be distributed for free in inany situations, then her argument should apply with equal force to national defense, the classic public

134. The classic example is T.S. Eliot's The Wasteland, which contains numerous quotations from other works of art. T.S. Eliot, The Wasteland, in MODERN AMERICAN POETRY \& MODERN BRITISH POETRY 202-13 (L. Untermeyer ed. 1955). Richard Posner has argued Eliot could have negotiated with each individual author quoted, an argument effectively rebutted by Fisher, supra note 9 , at $1730-31 \&$ n.303. 
good. The defense contractors should be told, as artists are, that they must allow their bombers and missiles to be used free of charge and thus sacrifice their potential profits for the public interest.

In summary, several characteristics of intellectual property provide an initially plausible explanation for various aspects of intellectual property law. But they offer at best an incomplete explanation for why we have one type of property regime for works of art and a different regime for other types of private property. To gain a more complete understanding of this dichotomy, we need to examine the underlying assumptions about the nature of copyright holders and users.

\section{The Nature of the Copyright Holder.}

a. The concept of the undeserving artist. In a society that judges a person's worth by his financial status, the artist often is held in contempt. ${ }^{135}$ Artistic work is considered "feminine" by the dominant masculine culture and therefore not worth serious consideration. ${ }^{136}$ Additionally, many laypersons think writing or painting is not particu-

135. One contemporary artist writes: "In America, our affluent, electronic, and materialist society does not respect the imaginative writer regardless of sex, race, color, or creed." Walker, On Being Female, Black and Free, in THE WRITER ON HER WORK 95, 104 (J. Steinberg ed. 1980). In Main Street, through his description of a typical American small town, Sinclair Lewis gives us repeated instances of this attitude toward artists. S. LEW1S, MAIN STREET (1948). For example, the heroine is told, "I'd of thought that after getting this look-in at a lot of good decent farmers, you'd get over this high-art stuff, but you hang right on .... [A]t a show-down you'd prefer Sam Clark to any damn long-haired artist." Id. at 199. The heroine ultimately concludes that "[t]he respectability of the Gopher Prairies ... is reinforced by vows of poverty and chastity in the matter of knowledge. ... To be 'intellectual' or 'artistic' or, in their own word, to bc 'highbrow,' is to be priggish and of dubious virtue." Id. at 266. A later section of the book illustrates the popular juxtaposition of artists and feminity. A young man with ambitions to become a poet is described as "the most awful mollycoddle-looks just like a girl. The boys call him 'Elizabeth' and they stop and ask him about the books he lets on to have read." Id. at 327.

136. See generally R. Pirsig, ZEN and THe ART of Motorcycle Maintenance 60-62 (1983). Pirsig describes the dichotomy between the classical and romantic understanding of the world and observes that " $[t]$ he romantic mode is primarily inspirational, imaginative, creative, intuitive...." And "when it is applied to 'science' is often romantic. ... In northern European cultures the romantic mode is usually associated with femininity ...." Id. at 61 .

Ironically, although being an artist is considered a "feminine" calling, it is usually recognized that the best pictorial artists have not been women. This phenomena is the subject of Germaine Greer's book, THE OBSTACLE RACE (1979). Greer's exhaustive study of woman painters gives countless examples of women being discouraged from their work or being patronized by lack of serious criticism. She concludes:

There is then no female Leonardo, no female Titian, no female Poussin, but the reason does not lie in the fact that women have wombs, that they can have babies, that their brains are smaller, that they lack vigor, that they are not sensual. The reason is simply that you cannot make great artists out of egos that have been damaged, with wills that are defective, with libidos that have been driven out of reach and energy directed into neurotic channels.

Id. at 327. 
larly hard work, that anyone can do it. In an accurate description of this attitude, W.B. Yeats wrote:

For to articulate sweet songs together

Is to work harder than all these, and yet

Be thought an idler by that noisy set

Of bankers, schoolmasters, and clergymen

The martyrs call the world. ${ }^{137}$

Even the once-hiberal California Supreine Court in Desny v. Wilder, ${ }^{138}$ an opinion favorable to artists, ${ }^{139}$ stated that "free-lance writers are not ... bound to the exalted standards to which doctors and lawyers are dedicated." 140

One result of this attitude is that the general public and legislators may not be particularly indignant about the ways intellectual property theory diminishes the worth of artistic work. Since most noncommercial artists are relatively powerless and cannot afford lobbyists, they are in a poor position to influence copyright law. ${ }^{141}$

b. The concept of the exalted artist. There is a strong, countervailing vision of the artist that is dianetrically at odds with the Philis-

137. W.B. Yeats, Adam's Curse, in The Collected Poems of W.B. Yeats 78 (1952).

138. 46 Cal.2d 715, 299 P.2d 257 (1956).

139. The Desny court recognized that an artist's ideas (unprotected by copyright) could be protected by a quasi-contract theory. For a general discussion of the idea/expression distinction, see Libott, Round the Prickly Pear: The Idea-Expression Fallacy in a Mass Communications World, 14 UCLA L. REV. 735 (1967).

140. $46 \mathrm{Cal} .2 \mathrm{~d}$ at 734,299 P.2d at 267. There are a number of similar expressions of judicial contempt for artists. For example, in Grant v. Kellogg, Co., 154 F.2d 59 (2d Cir. 1946), the judge dismissed the plaintiff's claim of property rights in the cartoon characters "Snap, Crackle and Pop" by saying "[p]laintiff's elfish imagination seems to have given him a mistaken idea of his rights." Id. at 60 . One interesting case exhibiting judicial indifference to an artist's interests is Columbia Broadcasting Sys. v. De Costa, 377 F.2d 315 (1st Cir.), cert. denied, 389 U.S. 1007 (1967). This ease involved a cowboy who appeared at rodeos under the name Paladin. He always dressed in black, wore a holster with a silver knight piece, and carried a card saying "Have Gun Will Travel." When he learned about the television series "Have Gun Will Travel," starring a character named Paladin, who wore black and had a silver knight piece on his holster, he sued in the district court on an unfair competition theory and won a jury verdict of $\$ 150,000$. The First Circuit overturned the verdict, stating "[o]ur Paladin is not the first creator to see the fruits of his creation harvested by another, without effeetive remedy." Id. at 317 . This case can be seen as a graphic example of the wisdom of the country song's advice:

Mamas, don't let your babies grow up to be cowboys.

Don't let 'em pick guitars and drive in big trucks;

Make 'em be doctors and lawyers and such.

E. Bruce and P. Bruce, "Mamas Don't Let Your Babies Grow Up To Be Cowboys" (appears on Waylon \& Willie, 1978 RCA records).

141. In the motion picture and television industries, artists do enjoy more protection through powerful trade unions, such as the Writers' Guild and lobbying organizations, and the influential Motion Picture Association of America (MPAA). The MPAA has had a tremendous success in influencing copyright and communications law to protect the motion picture industry's interests. (pamphlet describing activities available from the author). 
tinian, worthless artist model. European and American intellectuals view the artist as a special kind of human, almost magical in her ability to create beautiful works of art. J.G. Holland captured this view: "Artists are nearest God. Into their souls he breathes his life, and from their hand it comes in fair articulate forms to bless the world." ${ }^{142}$ This concept is the explanation for the extraordinary protection that European "moral rights" give the artist. ${ }^{143}$ In this country, however, the intellectuals who hold this view are often as lacking in influence as the artists themselves. ${ }^{144}$

\section{The Nature of the User: The Deserving Infringer Concept.} Copyright imfringers are not ordinary "thieves." Usually, they are either teachers ${ }^{145}$ or other artists. Not too surprisingly, law professors, who dominate what is written about copyright, are sympathetic with these

142. T. Edwards, The New Dictionary of ThOughts 32 (1960) (quoting J.G. Holland). For a criticism of the idealization of the artist, see Boyle, The Search for an Author: Shakespeare and the Framers, 37 AM. L. REv. 617, 629-33 (1988).

143. See supra notes 78-111 and accompanying text.

144. This lack of imfluence probably accounts for the absence of moral rights protection in the United States. See supra notes 92-101 and accompanying text.

145. In theory, teachers at most universities are bound by a set of Educational Copying Guidelines issued by a 1976 House Report. H.R. REP. No. 1476, 94th Cong., 2d Sess. 68, 68-70 (1976), reprinted in 1976 U.S. CODE CONG. \& ADMIN. NEws 5659, 5681-83; see Note, Fair Use of the Guidelines for Classroom Copying: An Examination of the Addison-Wesley Settlement, 11 RUTGERS COMPUTER \& TECH. L.J. 111, 113 \& nn.14-15, 117 n.42 (1985). These guidelines were highly criticized at their conception by the American Association of University Professors (AAUP) and the Association of American Law Schools (AALS). A letter from the AAUP to Chairman of the House Committee on Judiciary Subcommittee on Intellectual Property, Representative Kastenmeir, expressed "deep dismay" toward the guidelines, which it claimed would seriously interfere with the basic mission and effective operation of higher education ..." 133 CONG. REC. H10,880-02. Similarly, the AALS argued that " $[\mathrm{t}] \mathrm{h}$ realities of classroom teaching and the economics of our students are such that they cannot purchase or pay royalties on works other than the standard text and casebooks. ... Thus the teacher's choice is not between purchasing and copying; it is between copying and not using." Id. When used as a maximum standard, the guidelines allow an educator to use multiple copying for classroom use only when a brevity test and a spontaneity test is met. The brevity guidelines are highly restrictive-for example, a teacher cannot copy more than 1000 words of most works of prose. The copying also must be at the "instance and inspiration of the individual teacher" and this "inspiration and decision to use the work and the moment of its use for maximum teaching effeetiveness [must be] so close in time that it would be unreasonable to expect a timely reply to a request for permission." H.R. REP. No. 1476, at 69. In other words, if a professor plans in advance to pass out copyrighted material in her class, she will be prohibited from doing so unless she has received the holder's permission. Since many professors are not sure whom to write to in order to receive this permission and cannot endure the uncertainty in waiting for a reply when planning a syllabus in advance, they usually will choose not to use the material . . . or they will decide to cheat. It's a poorly kept secret in academia that the classroom copying guidelines are often ignored or rationalized away ("well, sure I first thought of using this material last summer, but I just decided to use it today").

This situation works to no one's advantage. It is unrealistic to expect individual users of educational photocopied materials to obtain permission from the copyright holder-the costs in time are too prohibitive, the temptation to cheat too great. Even Nimmer acknowledges this proposition-his 
infringers. The first fair use factor, which distinguishes between works used for commercial and noncommercial educational purposes, carries an exphicit inessage that educators "deserve" to use a copyrighted work for free, simce their motives are not private pecuniary gain, but rather educating the public. ${ }^{146}$ Moreover, artists "deserve" to use others' work in order to create additional works of art-another "unselfish," publiccentered motive.

Agani, analogies to other forms of property would produce imteresting results. It would shake the very foundations of our private property system if we always took into account the nature of the user of stolen property, the reasons for the theft, and the use to which the property is put. Jean Valjean might not have gone to prison if intellectual property law applied to loaves of bread. ${ }^{147}$ Although there are obvious political and pragmatic reasons why people may object to extending the deserving-user concept to other forms of property, ${ }^{148}$ it is difficult to think of a principled objection. Nourishing hungry young minds with free works of art is a nice idea, but feeding starving children is far more conıelling.

4. General Private Property Theory and Intellectual Property. In this section, I will discuss the reasons offered to justify the existence of private property in general, consider whether they apply to intellectual property, and determine whether the reasons for the restrictions in intellectual property should apply with equal force to other forms of property. As the basis for my analysis, I use the categories of property theories that Frank Michelman describes in his classic work, Property, Utility and Fairness: Comments on the Ethical Foundation of "Just Compensation" Law. ${ }^{149}$ Michelnian identifies three broad categories of theories that justify the existence of private property: (a) "desert and

casebook excerpt from Williams \& Wilkins includes a cartoon of a photocopier with a sign which reads:

Instructions:

1. Insert Quarter

2. Locate Copyright holder

3. Secure Permission

4. Pay Fee

5. Make Copy

M. NimMER, supra note 60, at 393.

146. This concept ignores certam realities. The professor receives a salary for her work. Although she does not charge students for the copyrighted work she distributes, she receives a benefit in time saved.

147. Jean Valjean is the hero of V. Hugo, Les Miserables (Dodd, Mead \& Co. 1900). He spent years in prison for having stolen a loaf of bread to feed his sister's seven starving children. Id. at $17-18$.

148. Among other things, if the poor were considered deserving infringers, it would result in widespread distribution of wealth.

149. Michelman, supra note 27. 
personality" theories, (b) social functionary theories, and (c) utilitarian theories. ${ }^{150}$ As I will demonstrate, all three theories have their counterparts in intellectual property doctrine.

I already have discussed the John Locke theory of property, which Michelman describes as a "desert" theory's1 (the proposition that a person deserves to receive the fruits of her labor), and the Hegel theory, which limks property to personality. ${ }^{152}$ I described the two as distinct theories with respect to intellectual property, since they can lead to different results in copyright law in areas such as noral rights, but they do share a common bond. Both theories focus on the relationship between the creator and the property, not on the effect of that relationship on society. ${ }^{153}$

Do the desert and personality theories explain the unique nature of the intellectual property regime? The answer inust be no. The fair use defense is totally unjustifiable under the Lockean view of property, which does not allow exceptions to its absolutist proposition that a person must either receive the actual product of her labor or receive just compensation for it. ${ }^{154}$ The personality theory, which many commentators believe makes an even stronger case for possession of intellectual property than for other types of "ordinary" property, is equally unhelpful in providing a reason for the fair use himitation on intellectual property, although it does explain the advantages given artists in countries that recognize inoral rights. ${ }^{155}$

Desert and personality theories might permit time duration rules, which do allow the original worker to receive the fruit of his labors, but also remove property rights froin his heirs. But there is nothing in the theories that justifies applying these rules to one type of property but not

150. Id. at 1203-13.

151. See supra notes $28-34$ and accompanying text.

152. See supra notes $44-48$ and accompanying text.

153. Michelman, supra note 27 , at 1205.

154. One major problem with the idea that it is only right to award the fruits of a person's labor to that person, is the fact that this concept does not translate well into our modern capitalist society, in which workers do not own the means of production. An automobile assembly line worker does not take home a hubcap at the end of the day, and if she were allowed to do so, it would be of little use to her. We have developed instead a system of monetary compensation for a person's services in creating property. Therefore, when applied to copyright law, although the desert theory does require that the artist receive some compensation for his work, it does not necessarily require that he receive ownership of the work itself. Stephen Breyer plays with this argument and dismisses the counterargument that this compensation may not equal the true value of the artistic creation, contending that "few workers receive salaries that appropriate the total value of what they produce. The social value of the work performed by the man who invents the supermarket, or the man who clears a swamp, the academic scientist, or the schoolteacher may bc much greater than his pay." Breyer, supra note 11, at 285.

155. See supra notes 79-92 and accompanying text. 
another. If it is just for a landholder's heirs, who have not created a work of property by the fruits of their own labor, to be given property (or its monetary equivalent) because of a fortunate accident of birth, then the heirs of an artist should enjoy the same windfall.

An argument could be made that intellectual property is not uniquely the artist's own because the artist must necessarily draw on the past experience and writings of others to enhance his own work. Under this view, production of intellectual property is seen as a collective enterprise, not individual labor. ${ }^{156}$ But all artists know that creation can be a uniquely lonely experience: At certain times there is nothing worse than being faced with a blank sheet of paper or canvas. Of course, an artist owes a great deal to those who have gone before her, but the same is true of all human beings. The baker did not invent the idea of mixing wheat with water and cooking it, his wife did not chop down the wood she used to build her breadbox. Therefore, if the desert and personahity theories with their einphasis on a just reward for the creator of property are correct, then they must apply equally to all forms of property.

Michelman's second category is that of social functionary theories. ${ }^{157}$ These theories do not center around the property holder, but rather focus on society at large. They assume that without the mcentive of private property ownership, there will be no production of property, and society will stagnate. ${ }^{158}$ Moreover, the most efficient method of consumption of property is through private ownership. These theories animate the purpose commonly supposed to be behind the copyright clause-to stimulate the progress of "Science and useful Arts."159 They are cited most often by proponents of the idea that copyright is a manmade right, created solely for the purpose of aiding production.

Would social functionary theories permit a fair use defense for all forms of property? The answer is a qualified yes. If the fair use defense was permitted only in situations in which it would not inhibit either production or consumption, it might be acceptable. This is the goal of the copyright commentators who argue that the critical test for fair use is whether the infringement affects the copyright holder's inarket. ${ }^{160}$

At this point, it is appropriate to consider again the characteristics of intellectual property that supposedly justify the fair use defense: An

156. See, e.g., K. MARX \& F. ENGELs, LITERATURE AND ART 1-23 (International ed. 1947).

157. Michelman, supra note 27, at 1206-08. Fisher describes what he characterizes as a "social utility" copyright goal, which combines Michelman's categories of social functionary theories and utilitarian theories. Fisher, supra note 9, at 1687-88.

158. This category of theory is fundamental to economic analysis. See, e.g., R. PosNer, supra note 12 .

159. U.S. CoNsT. art. I, § 8.

160. E.g., Raskind, supra note 9, at 601-39. 
infinite number of reproductions of the property can be made at low cost, and the use of any one reproduction will not substantially injure the property holder's market. ${ }^{161}$ To the extent that either of these characteristics are partially shared by other types of property, it would seem that a limited fair use defense would not deter the property holder's motivations for production. If the baker owned a bread factory capable of producing 10,000 loaves a day, fair use of 10 loaves would not add substantially to the baker's cost, ${ }^{162}$ would not injure substantially his market, and probably would not chill his incentive to produce. ${ }^{163}$ Therefore, if the concept that fair use is desirable when it serves the public interest but does not limit the copyright holder's motivation for production is true when apphed to intellectual property, then it should be true when applied, in limited circumstances, to other types of private property.

Under social functionary theories, the reason we allow property to be inherited is based on the idea that a person will work to provide not only for herself, but also for her heirs. There seems to be no evidence that artists are less concerned about their offspring than anyone else, ${ }^{164}$ and therefore no explanation under this theory for a limited duration rule applies solely to artists. Nor is it possible to completely justify the limited nature of the duration rule through a consumption analysis. It may be true that the public will suffer if Black Beauty's heirs refuse to sell the story for a reasonable price, but it may suffer even more if Blackacre's heirs refuse to sell Blackacre to provide low-cost housing in an area where it is severely needed.165

161. See supra notes $123-25$ and accompanying text.

162. There is one important difference between this example and the reproduction of intellectual property. Usually, the copying of artistic work is done by the prospective user; in my hypothetical, the baker himself must produce the extra loaves. However, since the costs in time and money to the baker are insignificant, this difference alone cannot explain why fair use of the bread is inappropriate.

163. This statement seems particularly valid if we consider fair use as a form of tax on the baker's work. Although the effect of taxation on production is complieated and cannot be gauged completely, it seems reasonable to say that in today's world taxes, even high taxes, are not a major detriment to production.

164. Indeed, Zechariah Chafee, Jr. argues that

[t]he biographies of authors show that they are more subject than most men to indolence. It is pleasanter to satisfy their active minds with conversation and observation and random reflections than to sit for many lonely hours at a table and push a pen. They must somehow be blasted out of this agreeable aimlessness, and one of the best ways is the hope of producing a competence for their children.

Chafee, supra note 8, at 508.

165. There is one plausible explanation for the difference. Black Beauty is truly unique; another children's book about a horse will not satisfy consumers in exactly the same way. Low-cost housing may be developed at another site. However, this explanation assumes that uniqueness and social utility are the same, an assumption that is dubious at best. 
Utilitarian theories of property, Michelman's third category, are based primarily on the works of Hume and Bentham. ${ }^{166}$ According to these theories, man's basic selfishness and insecurity require that rules about property must exist as a form of "mutual forbearance."167 Property laws are necessary if people are to live together in a civilized fashion. Moreover, rules alone are not enough. Utilitarian rules must be consistent and predictable, and they must establislı "secure expectations about future enjoyment of product." 168

The current fair use defense must be characterized as a disaster under a utilitarian analysis. A copyriglit holder cannot predict reasonably how many would-be "fair users" will use his property. Even worse, he must go to court before lie can receive a definitive answer about whether the user must compensate him for his property. Worse yet from the utilitarian's point of view, the copyriglit holder is not the only one left uncertain by the defense; the good faith user also can never be completely confident that a given use is "fair." Perhaps the only saving grace about the doctrine from the utilitarian's perspective is that it is limited to copyright law. Obviously, then, this theory will not support extension of the fair use defense to other types of property, but it also provides no reason for applying it solely to intellectual property and offers a good reason for abolishing the doctrine entirely.

Duration rules, on the other hand, are concrete and security-inducing. The intellectual property holder knows she will retain copyriglit protection throughout her lifetnne, and she also knows her heirs will enjoy the property exactly fifty years. Altliough a utilitarian analysis can justify duration limitations on intellectual property, it would be at best neutral as to whether they should be applied to other types of property. Unlike the labor and desert theories, which have justice as a central tenet, ${ }^{169}$ or the social functionary theories, which assume that the link between private property ownership and production and consumption is umiversal to all types of property, ${ }^{170}$ utilitarian theories do not necessarily require that all types of property be treated the same. They have been accused of upholding the status quo-if that is true, then a utilitarian could easily conclude that duration rules, which have existed over 200 years, are justifiable, but to remove a landowner's secured expectations that his land may remain in his family forever is unjustifiable.

166. Michelman, supra note 27, at 1208-13.

167. Id.

168. Id.

169. See supra notes 151-55 and accompanying text.

170. See supra notes $157-60$ and accompanying text. 


\section{RETHINKING THE ARTIST'S INTEREST}

\section{A. The Story of Four Contemporary Artists}

Every intellectual property theory shares an underlying assumption that all artists are alike and have similar interests. Yet in contemporary society, this is decidedly not the case. Today's creators of intellectual property vary widely in their work products, means of income, and need for legal protection. In this section I discuss four fictional artists who represent a cross-section of the contemporary artistic world. I examine the validity of the profit motivation assumption with respect to these artists, and the impact of the various umque aspects of copyright law on their work.

1. Margo. Margo is a writer based in California. Her primary work is creating ideas for new television programs and writing scripts for existing programs and motion pictures. Since she is a freelance writer, she usually continues to hold the copyright to her works, although in some instances her contract with a television production company will include the provision that the copyright belongs to her employer. ${ }^{171}$ Margo receives a minimum of $\$ 21,965$ for a first draft of a motion picture screenplay ${ }^{172}$ and $\$ 3923$ for a thirty-minute teleplay. ${ }^{173}$

171. Under the Copyright Act, when a person creates a work "for hire," the person "for whom the work was prepared is considered the author" and owns all the rights to the work unless expressly agreed otherwise in a written instrument. 17 U.S.C. $\S 201(b)$ (1988). The Act further defines works made for hire as

(1) a work prepared by an employee within the scope of his or her employment or (2) a work specially ordered or commissioned for use as a contribution to a collective work, or as a part of a motion picturc or other audiovisual work ... [other examples omitted] if the parties expressly agrec in a written instrument signed by them that the work shall be considered a work made for hire.

Id. $\S 101$. Approximately $40 \%$ of all copyright registrations are works for hire and the interpretation of the definition of "works for hire" has been the subject of a great deal of litigation, see Hardy, Copyright Law's Concept of Employment-What Congress Really Intended, 35 J. COPYRIGHT Soc'Y 210 (1988). I.T. Hardy criticizes the courts' different interpretations of the Act's provision, stating that they have misinterpreted Congress's intention in creating the provision. He argues that Congress used the word "employment" only to refer to "formal, regular, salaried employment ...." Id. at 257.

172. Theatrical and Television Basic Agreement: Writer's Guild of AMERICa 54 (1985) (copy on file available from the author) [hereinafter WRITER'S GU1LD AGREEMENT]. Like many successful writers, Margo is a member of Writer's Guild, a powerful union that sets minimum rates for compensation for various written works. The quoted figure is for a "high budget" motion picture, defined as a motion picture with a cost of over $\$ 2,500,000$. The rates for "low budget" movies are correspondingly lower. Id. at 53 .

173. Id. at 69. There are other opportunities for freelance employment of writers such as Margo:

AUDIOVISUALS: For writing; $\$ 125-250$ per requested scripted minute; includes rough draft, editing conference with client, and final shooting script. For consulting, research, producing, directing, soundtrack oversight, etc., $\$ 300-500$ per day plus travel and expenses. Writing fee is sometimes $10 \%$ of gross production price as billed to client .... 
2. John. John is a painter who produces approximately ten paintings a year. His work is just beginning to coine into prominence, and he has been exhibited in several major art galleries. ${ }^{174} \mathrm{He}$ receives an average of $\$ 500$ a painting. This means if he sells all ten paintings, his incoine froin his art will be $\$ 5000$ a year. Last year, John sold two paintings for $\$ 1000$. His principal source of income was his job as a bank teller for which he receives $\$ 15,000$ a year. ${ }^{175}$

COMEDY WRITING FOR N1GHT CLUB ENTERTA1NERS: Gags only, \$2-25 each. Routines, $\$ 100-1000$ per minute. Some new comics may try to get a five-minute routine for $\$ 150$; others will pay $\$ 2,500$ for a five-minute bit from a top writer . . .

RECORD ALBUM COVER COPY: $\$ 100-250$ flat fee.

TV DOCUMENTARY: 30-minute 5-6 page proposal outline, $\$ 250$ and up; $15-17$ page treatment, $\$ 1,000$ and up; less in smaller cities.

TV EDITORIALS: $\$ 35$ and up for 1-mimute, 45 seconds (250-300 words).

TV INFORMATION SCRIPTS: Short 5-10-minute scripts for local cable TV stations, \$10-15/ hour.

TV INSTRUCTION TAP1NG: \$150 per 30-mimute tape; $\$ 25$ residual each time tape is sold.

TV NEWS FILM STILL PHOTO: \$3-6 flat fee.

TV NEWS STORY: $\$ 16-25$ flat fee.

TV FILMED NEWS AND FEATURES: From \$10-20 per chip for 30-second spot; $\$ 15-25$ for 60-second clip; more for special events.

TV, NATIONAL AND LOCAL PUBLIC STATIONS: \$35-100 per minute down to a flat fee of $\$ 100-500$ for a 30 -to 60 -minute script.

1988 WRITER's MARKET 998-1003 (G. Neff ed. 1987).

174. The gallery-artist relationship has emerged as the primary means of marketing the artist's work. Gallery directors and dealers act as marketing agents for selected artists by providing the forum and publicity necessary to exhibit and ultimately sell the artist's work. The selection of which artists a gallery vill represent appears to be quite arbitrary. As one commentator explains:

Current enthusiasms im the art world play a large part in determining which painters are in demand. In addition, gallery directors are often guided by the recominendations of colleagues and other artists, or-much inore rarely - they will decide to exhibit on the basis of a set of slides sent to them unsolicited by an artist.

R. SMITH, THE ARTIST'S HANDBOOK 332 (1987).

The price of this marketing depends upon the location of the gallery, the type of collector the gallery attracts, and the amount of responsibility the gallery undertakes towards the exhibition (management of business matters, such as invoicing, accounts, and negotiations with prospective buyers; as well as framing, transportation, and storage). Id. at 332. One observer of the "art game" describes the business relation of artist to dealer as follows:

Generally, when an artist has a one-man show, the dealer's share is $331 / 3 \%$ of the proceeds of all sales. In some cases it is as high as fifty per cent .... When he gives an unknown artist an exhibition the dealer takes a gamble that justifies the high rate of commission. But there is no reduction in the rate of cominission if the artist proves to be a big success .... Thus the dealer's initial gamble can prove to be usefully profitable and . . . to his advantage to bind the artist to him by contract .... But it is also said that the [contract] systein gives the dealer too much power over the artist, and that the artist is no longer his own master and is told not only when, where, and for how much his work shall be sold but also what sort of pictures he must paint, and in this there is certainly some truth.

R. Wraight, The ARt Game Again! 196-97 (1974).

175. The median annual earnings for a bank teller in the United States is $\$ 12,000$. The median of the lowest $10 \%$ of bank teller salaries $\$ 8500$ and that of the top $10 \%$ is $\$ 18,700$. BuREAU OF Labor Statistics, U.S. DeP'T OF LABOR, OCcupational OUTLOOK HaNDbook 230 (1988) [hereinafter OCCUPATIONAL OUTLOOK HANDBOOK]. 
3. Susan. Susan is a poet whose work has been published in major poetry magazines such as Poetry, which has a circulation of $6500 .{ }^{176}$ She has been praised by important critics and received several prizes. ${ }^{177}$ Her incoune from the sale of her poetry usually amounts to $\$ 1500$ a year, however she received a $\$ 10,000$ grant last year. ${ }^{178}$ Susan has published three books of poems for which she has received a total incone of $\$ 4500$ over a period of ten years. ${ }^{179} \mathrm{Her}$ primary income is her $\$ 30,000$ salary as a hiterature professor at a less-than-prestigious university. ${ }^{180}$ Susan's

176. Poetry magazine was established in 1912. UlRICH's INTERnational Periodicais DIRECTORY 1988-89, at 170 (27th ed. 1988). Poetry publishes approximately 25-30 poems per monthly issue and pays $\$ 1$ per lime. Telephone interview with staff of Poetry magazine (June 1988).

177. The Poetry Society of America presents several annual awards for poetry: the Bernice Ames Memorial Award (\$100), the Gordon Barber Memorial Award (\$200), the Gertrude B. Claytor Memorial Award (\$250), the Gustav Davidson Memorial Award (\$500), the Mary Carolyn Davies Award (\$250), the Alice Fay di Castagnola Award (\$2000), the Consuelo Ford Award (\$250), the Cecil Hemley Award (\$300), the Alfred Kreymborg Memorial Award (\$100), the Lucille Medwick Memorial Award (\$500), the Christopher Morley Award (\$500), the Shelley Memorial Award (\$1750), the Cecil B. Wagner Memorial Award (\$250), the Emily Dickinson Award (\$500), the Melville Cane Award (\$100), the John Mansfield Award (\$500), and the William Carlos Williams Award (purchase of 500 copies of winning book of poems).

Poetry Magazine also sponsors the following awards annually: the Oscar Blumenthal Prize $(\$ 100)$, the Jacob Glatstein Memorial Prize $(\$ 100)$, the Bess Hokin Prize $(\$ 100)$, the Levinson Prize (\$300), and the Eunice Tietjens Memorial Prize (\$200). LiteraRY AND LibraRY PrIzes 357-85 (10th ed. 1980).

178. The National Endowment For The Arts is the primary source of annual fellowships and grants for writers. The purpose of the grants is "[t]]0 assist individual creative writers of excellence or promise." ANNUAL REGISTER OF GRANT SUPPORT 26 (3d ed. 1990) (\$20,000 per award).

The Academy of American Poets rewards poets of proven merit through a fellowship, Academy of American Poets Fellowship (\$10,000). Id. at 254.

Through The Mildred and Harold Strauss Livings Program, the American Academy and Institute of Arts and Letters provides two writers with annual stipends of $\$ 50,000$ "so that they can devote their time exclusively to writing." Id. at 255.

179. Royalty rates for trade books vary, as they are based on the list price of the book. But "[f]or clothbound sales in the United States, the common industrywide rate is: 10 percent for the first 5,000 copies sold, $121 / 2$ percent on the next 5,000 copies sold, and 15 percent thereafter." $R$. BALKIN, A WRITER's GUIDE TO BOOK PUBLISHING 58 (1977). "The mean advance for trade books is roughly $\$ 3,000$ to $\$ 5,000$." II. at 70 .

Because of the limited market for books of poetry, the royalty rates and advance payments are substantially lower than the median rates for trade books in general. Although advance payments for poetry books can range from $\$ 300$ to $\$ 3000$, the average advance is $\$ 500$. Royalty rates for books of poems generally range from 6 to $10 \%$, with an average of $8 \%$ for the first 5000 hardbound copies sold, and 10\% thereafter. Telephone interview with Bob Scharrard, City Lights Books in San Francisco (July 1988).

180. The average salary for all ranks of faculty in Letters is $\$ 32,605$. The range of salaries is from $\$ 7750$ to $\$ 73,440$. These statistics are based on a survey of 272 state colleges and universities and 5519 professors in the discipline of Letters (which includes major fields of English, Linguisties, Speech, Forensic Science, and Classics). College and University Personnel Ass'N, NATIONAL FACULTY SALARY SURVEY BY DISCIPLINE AND RANK IN STATE COLlEGES AND UNIVERSITIES 1987-88, at 29 (1987).

Another survey found the average salary for all ranks of faculty in English to be \$32,315, with a range from $\$ 10,800$ to $\$ 86,000$. These statistics are based on a survey of 3405 professors of English 
academic reputation is primarily contingent upon her reputation as a poet, and her publications were critical to her award of tenure. Although she is reasonably content at her present job, she would like to receive a teaching appointinent at a inore prestigious institution. ${ }^{181}$

4. David. David is the head of an ultra-conservative "think tank." In this capacity, he authors numerous position papers, which are copyrighted by his institution. Additionally, he writes many books, freelance newspaper columns and book reviews, all of which are intended to promulgate his political views. His latest works include a biography of President Nixon and a historical novel about the late 19th century (in which he suggests that reports of the excesses of laissez-faire capitalisin were greatly exaggerated). David receives a $\$ 100,000$-a-year salary from his institute. His earnings from his independent works vary from $\$ 10,000$ to $\$ 50,000$ a year although he expects the biography to be a very profitable bestseller.

\section{B. The Incentive for Creation}

Dr. Samuel Johnson, the cymical and wealthy compiler of Johnson's Dictionary, stated that "[n]o inan but a blockhead ever wrote except for money." 182 The sentiment expressed in this repeatedly cited quote is considered the classic incentive for the artist. ${ }^{183}$ Its fundamental flaw is the assuinption that all artists are inotivated primarily by monetary interests. If this assuinption were true, it would be difficult to explain why

in 96 state universities and land-grant colleges. OFFICE OF INSTITUTIONAL RESEARCH, OKLAHOMA State University, 1986-87 Faculty Salary SuRVey of Institutions Belonging to NaTIONAL Ass'N Of STATE UNIVERSITIES AND LAND-Grant Colleges, B-107 (1987).

181. It has become uncommonly difficult for faculty members of colleges and universities to move up the institutional pecking order in recent years as a result of a substantial decrease in available teaching positions. Faculty inobility, however, has long been a valued asset in attracting professionals to academe:

It often enables faculty inembers to be promoted when they are faced with no available openings in their present situations; it sometimes enables them to be placed in positions closer to their interests; it also enables thein to gain refreshment and stimulation from new colleagues and new experiences; and it helps to combat declining morale.... The game of musical chairs is an important feature of academe and will surely continue to be played during the years ahead ..... Indeed, if inter-institutional moves are counted, it is likely that the turnover rate will be at least double the 3 to $6 \%$ rates [from academe to the general labor market] we have assumed.

H. Brown \& J. Schuster, American Professors-A. National Resource Imperiled 199 (1986).

182. J. BosWell, Life of SAMUEL Jorinson 623 (1791).

183. The vast majority of copyright coinmentators, and apparently a majority of the Supreme Court, accept this dogma as given. Wendy J. Gordon, for example, characterizes it as the "core" of copyright doctrine, Gordon, supra note 9, at 1619. But see Ladd, supra note 33, at 421-22 (rejecting the argument that only copyright infringement that causes economic harm to the authors should be prohibited). 
imtelligent, presumably rational people ever become artists, a word more often associated with the adjective "starving" than with "wealthy."

In the book On Becoming a Novelist, author John Gardner tells his readers: "The study of writing, like the study of classic piano, is not practical but aristocratic. If one is born rich, one can easily afford to be an artist; if not, one has to afford one's art by sacrifice."184 Gardner's description of the artist's earning capacity certainly is supported by einployment statistics. According to a report issued by the National Endowment for the Humanities, "Most artists cannot make a living practicing their art, and have to do non-art work to survive."185 A coinprehensive survey of all authors who have published at least one book showed that seventy percent were engaged in work other than writing. ${ }^{186}$ Thirty-six percent of thein were engaged in Susan's occupation: teaching. ${ }^{187}$ With respect to visual artists like John, the Bureau of Labor Statistics Occupational Outlook Handbook states: "Only the most successful are able to support theinselves solely through sale of their works ...."188 The aspiring millionaire would be better off in econoinic terms by going to medical school than becoming an artist: A doctor's average salary ranges from a high of $\$ 203,570$ to $\$ 72,840^{189}$ whereas the average median incoine for an artist (froin all sources) was $\$ 9,800$ in

184. J. GARDNER, ON BeCOMING A NOVELIST 74 (1983).

185. National ENDowment for the ARTs, Five Year Planning Document 23 (Feb. 1984) [hereinafter NEA PlanNing Document].

186. P. Kingston \& J. COLE, The WAGES OF WRITING 48 (1986) (based on 1979-1980 data; figures unadjusted for infiation). The authors conducted a survey of 2,241 authors to reach their results. They described these results as the "best estimates yet available" of the economic situation of American authors. Id. at 2. The report showed that the median author in the survey earned a total of $\$ 4775$ from writing. A quarter of the authors earned less than $\$ 1000$ from their writing; $10 \%$ had a writing income of more than $\$ 45,000$; $5 \%$, more than $\$ 80,000$. Id. at 5 .

P.E.N. International, an association of poets, playwrights, editors, essayists, and novelists polled 358 of its members and found that the median income of its members in 1978 was $\$ 4700$, while the average was $\$ 21,192$. P.E.N. International, News Release (undated) (file on copy in journal office) [hereinafter P.E.N. Survey]. Both the P.E.N. and the Kingstand Cole Surveys' results include successful writers-Kingston \& Cole only surveyed authors who had published at least one book. See P. KINGston \& J. ColE, supra, at 3. P.E.N. members are described as "established individuals in the fields of publishing and letters." P.E.N. Survey, supra, at 5. Thus, it is likely that the income for beginning authors is far lower.

187. P. Kingston \& J. ColE, supra note 186 , at 49 . The P.E.N. Survey reported that $55 \%$ of its respondents were teachers. See P.E.N. Survey, supra note 186, at 2.

188. Occupational OutlooK HANDBOoK, supra note 175, at 192. The Handbook also indicates that a sizeable number of artists teach art in secondary schools, colleges, or universities. Id.

189. The Occupation Outlook Handbook gives the following median net income for practicing physicians in 1986: 
1980. 190 Even artists who are generally regarded as "great" often do not achieve financial success--Van Gogh, for example, only sold one painting during his lifetime. ${ }^{191}$ It also is widely known that very good artists often earn less money than purely commercial ones. As John Stuart Mill put it: "[T] $]$ he writings by which one can hive are not the writings which themselves live."192

If monetary gain is not their primary motive, then why do so many people continue to produce intellectual property? There is no single an-

Table 1. Median net practice income by medical specialty, 1986

Neurosurgeons
Orthopedic surgeons
Plastic surgeons
Thoracic surgeons
Ophthalmologists
Radiologists
General surgeons
Internists
Psychiatrists
Family practitioners
Pediatricians
General practitioners

$\$ 203,570$
182,640
180,210
156,480
148,000
147,500
122,370
95,630
86,670
86,430
84,340
72,840

OCCUPATION OUTLOOK HANDBOOK, supra note 175, at 132 (according to a survey of office-based physicians conducted by Medical Economics).

190. NEA Planning Document, supra note 185 , at 23 . The survey stated that although the median income had increased froin $\$ 7900$ in 1970 to $\$ 9800$ in 1980, this increase "represeuted a decline in real terms of $42 \%$." Id. The report also showed that woinen and minorities received lower incomes than their white inale counterparts. Id.

The survey defined artist as an "aggregate" of the following oceupations: actors, architects, authors, dancers, designers, inusicians/composers, painters/sculptors, photographers, radio/T.V. announcers, teachers and "[o]ther [a]rtists not elsewhere classified." Id. at 83. Data was taken from statistics of the Bureau of the Census, the Bureau of Labor Statistics, and the HEW Survey of Income and Earnings. The breakdown of earnings was as follows:

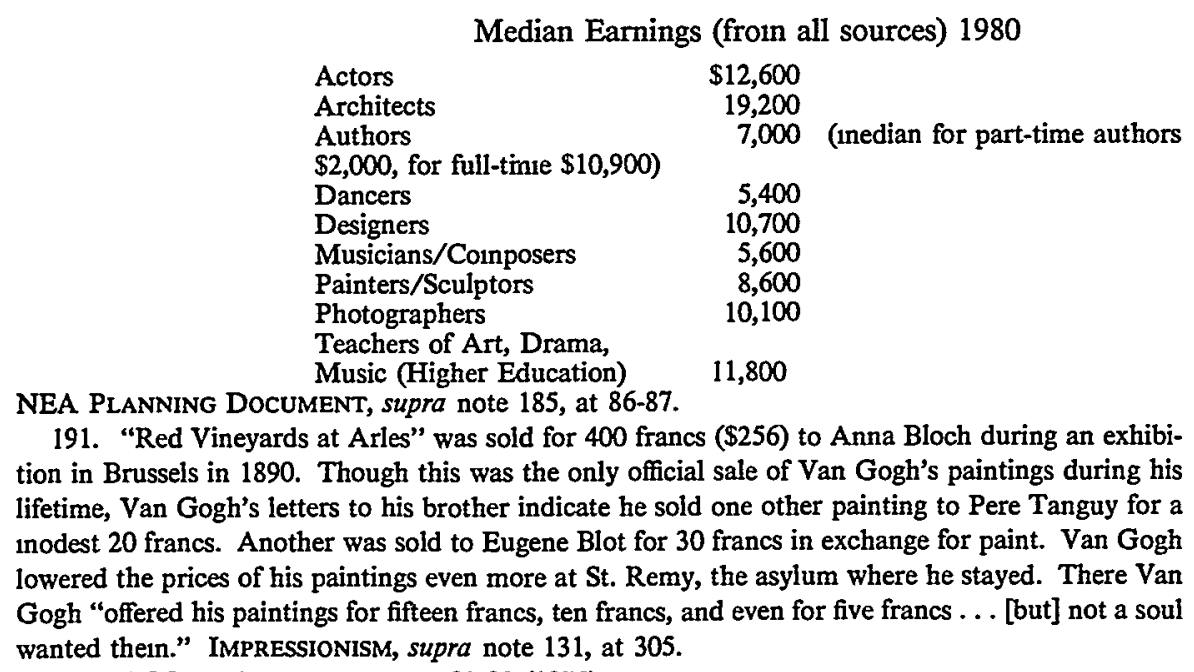

192. J. Mill, AUTOBIOGRAPHY 82-83 (1875). 
swer; most artists work for a variety of motives. Many work for fame or recognition among their peers. Susan is an example of this type of person. To her, the critical reception her poems receive is far more important than the money they make. Artists like David also write for the benefit of an audience, but for a different reason-the desire to promulgate their political, philosophical, or religious views. ${ }^{193}$ Novelist and short-story writer Tom Bambara tells us: "Writing is one of the ways I participate in struggle ... . Through writing I attempt to celebrate the tradition of resistance, attempt to tap Black potential, and try to join the cliorus of voices that argues that exploitation and misery are neither inevitable nor necessary." 194

Otlier artists do not create for an audience but rather for themselves. For them, the need to write or paint is an integral part of their personality. ${ }^{195}$ Novelist Joan Didion is typical: "I write entirely to find out what I'n thinking, what I'm looking at, what I see and what it means. What I want and wliat I fear."196 Most artists simply cannot imagine any other life. Gardner writes, "Nothing is harder tlian becoming a true novelist, unless that is all one wants to be, in which case, thougli becoming a true novelist is hard, everytling else is harder." 197

Of course, a significant number of people imdeed do create exclusively to make inoney; the character Margo is an example. But the assumption that the financial inotive is unversal is simply incorrect and slould not contimue to be the exclusive foundation of copyright law.

I do not inean to imply that money is not important to artists. Many of them indeed may prefer "roses" in the form of fame or selffulfillinent to bread, but the hard fact is that in a capitalist society they cannot survive without some sort of financial support. Copyright law does allow an artist to receive direct financial compensation for lis work, but this support is often inadequate: Soine $8.5 \%$ of all artists were below the poverty level in 1980 , coinpared to $5.5 \%$ of the general population. ${ }^{198}$

193. The existence of "vanity presses," which publish an author's work for a price which the author pays, is evidence of this motivation for creativity.

194. Bambara, What It Is I Think I'm Doing Anyhow, in THE WRITER ON HER WORK, supra note 135 , at 154 .

195. The P.E.N. survey asked its members what influenced them to become writers. They were allowed to check more than one applicable choice. Of the 358 respondents, 282 checked "need to write." In contrast, only 17 respondents checked "financial opportunities" (the lowest number). P.E.N. Survey, supra note 186, at 4. It is noteworthy that P.E.N., whose president was the wellknown novelist Bernard Malamud, is an organization of successful writers- $-8 \%$ of its respondents were in the $\$ 50,000-\$ 800,000$ income bracket. Id. at 2. Yet even these established artists regarded financial opportunity as their least popular reason to write.

196. Didion, Why $I$ Write, in THE WRITER ON HER WORK, supra note 135, at 20.

197. J. GARDNER, supra note 184, at 70.

198. NEA PLANNING DOCUMENT, supra note 185 , at 85. 
If most artists cannot support themselves by their work alone, then they must search for alternative work that will provide an adequate standard of living. Gardner suggests that the answer for an artist is to hive off his or her spouse, ${ }^{199}$ but this suggestion will not appeal to or be open to everyone. For many artists, as the examples of Susan and John suggest, the answer is to find employment that provides financial security. But this choice is not without costs. For John, a nine-to-five job means many hours spent not painting. Susan is fortunate because writing poetry is considered part of her work, but she may find her need to publish adversely affects her work. 200

Increased government subsidies for the arts ${ }^{201}$ could provide artists with basic financial security and free them to devote more time to creat-

199. J. GARDNER, supra note 184, at 117 . He acknowledges that this reaction is "psychologically ... hard," because of our cultural expectation that "one should never be dependent." Id.

200. In her book, Finding the Words, Nancy Bunge interviewed published writers who teach, to determine whether the halls of academia enhance or silence creativity. N. BUNGE, FINDING THE WoRDS (1985). As Seymour Epstein remarked, a writer "these days is rather in the position of the scholar in the dark ages who found sanctuary in the church. Your creative person finds sanctuary in the university today." Id. at 36.

Several of the writers stated that teaching had a positive effect on their writing. "I thimk that going to work every day helps. Tcaching in particular may help because it gets the words stirred up in your mind." Id. at 12 (quoting Marvin Bell). "I find when I'm teaching in a writing class, I'm inspired to do more work." Id. at 155 (quoting Anne Waldman).

I don't think that teaching has ever taken up my writing time. ... In my teaching, I've always kept my mornings free for writing and I couldn't use more time than that anyway. .... If I'm teaching books that I admire very much, it probably is an incentive. ... [T] eaching is probably beneficial in a great many different ways, not all of which I recognize.

Id. at 91-92 (quoting N. Scott Momaday).

Other writers bemoaned the loss of time and creative energy teaching exacted. "It takes a day away from my writing each week. . . . I would probably have had two more novels out by now; maybe even threc." Id. at 80 (quoting Fredrick Manfred). "Real writing cannot be done in anyone's spare time." Id. at 31 (quoting Kelly Cherry). "I write less because I give all to my teaching." Id. at 84 (quoting James Alan McPherson).

I find it very difficult to teach and write at the same time: I have to feel the entire day is mine for my own work. At Columbia it was set up so that [I taught] only one day a week, and even then it was as though $I$ had opened myself up to inroads on my imaginative energy. Once I had done that, I couldn't turn off the rest of the week. . . . I don't think I wrote three lines during that spring semester.

Id. at 184 (quoting Helen Yglesias).

Although for some of these writers the "sanctuary" of teaching can imprison rather than protect their crcativity, "[m]aking a living as a writer is such a hazardous business that there has to be something to fall back on. What the writer falls back on is teaching. In an unsatisfactory world, it's the best place for the writer to be." Id. at 36 (quoting Seymour Epstein).

201. In the National Foundation on the Arts and Humanities Act of 1965, Congress created the National Endowment for the Arts (NEA) to "foster the excellence, diversity, and vitality of the arts in the United States, and to help broaden the availability and appreciation of such excellence, diversity and vitality." Statement of Mission, in NATIONAL ENDOWMENT FOR THE ARTS, 1987 ANNUAL REPORT 222 (1988) [hereinafter NEA ANNUAL REPORT]. The NEA activities are aceomplished with the advice of the 26-member National Council on the Arts, a staff of 265, 7 regional representatives and over 600 panelists representing the various fields of art, NEA PLANNING DocUMENT, 
ing artistic works. ${ }^{202}$ But this alternative has its own drawbacks. Most serious from the artists' perspective are the possibilities that only recognized artists will be rewarded to the detriment of promising beginners or people outside the cultural main stream. ${ }^{203}$ Moreover, this alternative

supra note 185, at 38. The administrative budget of the NEA in fiscal 1987 was $\$ 16.1$ million with a total budget of $\$ 170.9$ million. ANNUAL REPORT, supra, at 232. (The total budget of the NEA for 1987 amounted to $0.017 \%$ of the 1987 federal budget of $\$ 1,015.6$ billion. BUREAU OF THE CENSUS, U.S. DEP'T OF COMMERCE, STATISTICAL ABSTRACT OF THE UNITED STATES 1988, at 291 (108th ed. 1987). The funds were appropriated as follows:

\begin{tabular}{lrc} 
& 1987 Obligations & $\begin{array}{c}\text { Challenge Grant } \\
\text { Commitments/Obligations }\end{array}$ \\
\cline { 2 - 3 } Dance & $\$, 123,750$ & $\$ 3,050,000$ \\
Design Arts & $4,450,793$ & $3,250,000$ \\
Expansion Arts & $6,747,560$ & $1,425,000$ \\
Folk Arts & $2,997,900$ & 400,000 \\
Inter-Arts & $4,044,305$ & $3,323,000$ \\
Literature & $5,028,076$ & - \\
Media Arts & $12,910,500$ & $2,900,000$ \\
Museum & $11,496,950$ & $13,350,000$ \\
Music & $15,059,910$ & $10,975,000$ \\
Opera-Musical Theater & $5,817,000$ & $3,750,000$ \\
Theater & $10,776,950$ & $4,800,000$ \\
Visual Arts & $6,224,440$ & $1,000,000$ \\
Arts in Education & $5,644,521$ & 650,000 \\
Locals Test Program & $2,255,230$ & - \\
State Programs & $24,591,800$ & - \\
Advancement & $2,471,797$ & - \\
Policy, Planning, and Research & 930,651 & - \\
TOTAL FUNDS OBLIGATED & $\$ 130,572,133$ & $\$ 48,873,000$
\end{tabular}

NEA ANNUAL REPORT, supra, at 228. NEA funding is allocated to four concerns: support of individual artists, arts institutions, audience development, and arts education. The NEA seeks to assist artists by providing direct funding to creative artists through fellowships and indirect funding of performing artists through the institutions that make their art possible.

The arts institutions supported by the NEA in 1983 received $50 \%$ of the grants issued. NEA PlanNing Document, supra note 185 , at 29 . The funds were distributed to commercial institutions such as publisliers, art galleries, major film studios, record companies, and Broadway shows, as well as non-profit institutions such as performing arts centers, orchestras, museums, small literary presses, and dance companies. To avoid the possibility of government domination of cultural life of the nation, the NEA is forbidden under the 1965 Act from funding nore than $50 \%$ of the costs of the art institutions it supports. M. STRAIGHT, TwIGS FOR AN EAGLE'S NEST: GOVERNMENT AND THE ARTS: 1965-1978, at 87 (1979).

For a thorough discussion of the potential of state government to aid artists, see Price, State Art Councils: Some Items for a New Agenda, 27 Hastings L.J. 1183 (1976). Price makes the fascinating suggestion that there should be a public riglit to have works of art exlibited. Id. at 1188. This suggestion would fit in well with my proposed "community interest" analysis. See infra notes 233. 39 and accompanying text.

202. Economists night object to this, arguing that because any subsidies would be low and limited then artists would lack sufficent incentive to create. However, the fact that artists do not work only for money undermines this argument.

203. Cultural funding by federal and state agencies such as the NEA and the New York State Council on the Arts involves a peer review system in which panels of selected niembers from the private sector review grant applications of their peers in their respective artistic disciplines. Despite its success, lowever, conflicts of interest pose one of the most serious drawbacks in peer review. The potential for fraternalism and elitism among peer reviewers with interlocking professional relationships, who may benefit either directly or indirectly from their own evaluations, requires the imposition of the strictest etlical safeguards. Cf. Aviation Consumer Action Project v. Washburn, 535 
raises the dangers of government censorship. ${ }^{204}$ From the public's perspective, there are also many difficult policy questions regarding the type

F.2d 101, 107-08 (D.C. Cir. 1976) (the disclosure of an intra-agency memorandum to an advisory committee does not make the memorandum public information under FOIA which is "designed to encourage a free and candid exchange of ideas during the process of decision-making"); Consumers Union v. Department of Health, Educ., and Welfare, 409 F. Supp. 473, 476 (D.D.C. 1976) (the court noted that the purpose of the Federal Advisory Committee Act is to prevent advisory groups from becoming self-serving), aff'd, 551 F.2d 466 (D.C. Cir 1978).

204. In September of 1989, the House of Representatives rejected a controversial amendment authored by Senator Jesse Helms that had passed in the Senate in a voice vote. Healy, Government-A Good Patron but a Bad Censor, N.Y. Times, Sept. 15, 1989, at A31, col. 2. The amendment attached to the appropriations bill for the National Endowment for the Arts, which contained $\$ 170$ million for the coming year, prohibited the use of federal funds to "promote, disseminate or produce obscene or indecent materials" (a definition drawn from the 1973 Supreme Court decision, Miller v. California, 413 U.S. 15 (1973)), or work that "reviles a person, group or class of citizens on the basis of race, creed, sex, handicap, age, or national origin." Id. The controversy arose over two photography exhibitions, one of works by the late Robert Mapplethorpe and the other featuring artist Andres Serrano. Mapplethorpe's homoerotic and sadomasochistic subject matter and Serrano's image of a crucifix submerged in the artist's urine prompted Congress to cut $\$ 45,000$ from NEA funds and further to ban for five years endowment grants to the two art organizations that organized the exhibits. Gomarekian, Endowment Nominee Making Rounds Center, N.Y. Times, Sept. 12, 1989, at C16, col. 2. Shock and anger over the Helms amendment prompted government funding critics and supporters alike to condemn the breadth of such attempted control. According to John Walsh, director of the Getty Museum in California,

artistic decisions have to be protected from political pressures. Who's going to decide what's 'indecent' or what 'denigrates the belief' of a particular religion or nonreligion? It's excellence that has to be the criterion, and the endowment's process of using peer panels of professionals to make those judgments has worked extremely well for twenty-five years.

Gluade, Senate Vote Prompts Anger, but Some Approval, in the Art World, N.Y. Times, July 28, 1989, at B6, col. 1.

Stephen Breyer, supra note 11, also discussed the danger of government censorship, giving as an example a member of the House of Un-American Activities Committee's question to a witness: "You are quoting from ... Marlowe. Is he a Communist?" Breyer, supra note 11, at 308 (citations omitted). Michael Straight also raises this possibility. He recounts two scrapes with Congress from controversies arising out of grants to individual artists. One involved the Endowment's grant of a fellowship to Erica Jong to assist her in the writing of a novel. The only stipulation made by the NEA was that Erica Jong should acknowledge the Endowment's aid if her work were published. She agreed and on the first page of her critieally acelaimed novel, FEAR OF FLYING (1973), she thanked the NEA for its assistance in funding the novel. The next page listed the title of chapter one: "En Route to the Congress of Dreams or the Zipless Fuck." The outcries about the public funding of Fear of Flying reached the ears of Senator Jesse Helms, who objected strongly to the Chairperson of the NEA. Though the issue was dropped because of Senator Helms' more pressing matters, the NEA came face-to-face with the threat of censorship. M. STRAIGHT, supra note 201, at 135.

Congressional censorship not only threatened that which could be judged obscene, but also that which was judged frivolous. Senator Proxmire presented the NEA with his Golden Fleece Award for funding the work of an Anti-Object artist who received $\$ 6025$ for throwing colored streamers out into the sky froin a small plane. "'I'm sculpting in space,' she told a reporter later. 'A black streamer looks like a crack in the sky. Red and yellow streamers look like huge lines, lashing at the earth.' By making people look upward, she added, her work 'called attention to the higher spirit of mankind." M. STRAight, supra note 201, at 166 . Senator Proxmire concluded that the "federal government simply must stop spending this kind of hard-earned tax money for this kind of artistic frou-frou." Id. at 168. 


\section{of art which deserves subsidization ${ }^{205}$ and the extent to which individual artists versus institutions should receive grants. ${ }^{206}$}

Straight's fear is that such congressional criticism will be the undoing of the NEA either in fact, by abolishing the Endowment, or in effect, by allowing government censorship of the arts. He accepts the argument for direct grants to individual artists that was presented by Nancy Hanks, the former Chairman of the NEA:

[W] hat about the artist who receives no-strings-attached support and creates a work that triggers controversy? Too often, the work of a rising talent is ignored, sometimes one becomes a celebrated cause. Nurturing the broad range of the Nation's creativity is far inore important than the few tempests that arise .... The programs cannot be tested against the criteria of instant success-or-failure. The concept of encouraging individual creativity is the goal. . . . Some art will be critieized; universal, instant popularity has never been a reliable index of artistic inerit. Throughout history too, many great artists have depeuded on patronage because art has so rarely been self-supporting. These facts simply create other problems when the patronage comes from public sources, corporations or foundations.

Id. at 146. Straight does not assert that the creative artist should not be funded, only that funding should be granted indirectly through art institutions and literary presses. He advocates offering matching funds to orchestras and operas to commission new works, as well as to publishers to pay advances for "works of unusual inerit but limited appeal." Id. at 171. The Endowment, he argues, will be less vulnerable to criticism of frivolity and obscenity if it funds "ten cents on the dollar of the budget of the La Mama Theater Company" which produces controversial works. Id. at 170 .

The concern about government censorship is well-founded, but academia, which is traditionally viewed as a place where the author may write free from censorship, may be just as bad as the government. See generally E. ScHRECKER, No IVORY TOWER: MCCARTHYISM AND THE UNIVERSITIES (1986) (describing repeated firings of left-wing teachers). The recent onslaught of tenure denials aud negative hiring decisions made against members of the critical legal studies inovement may provide a inore chilling example of censorship than any recent government action. See Frug, McCarthyism and Critical Legal Studies, 22 HARv. C.R.-C.L. L. REv. 665 (1987).

205. In spite of its lofty goals, the NEA has not been without its critics. Edward Banfield in his book, THE DEMOCRATIC MUSE, attacks the goals of the NEA as a "set of vague and conflicting statements of good intentions based on gross misperceptions of the nature of art and of the amount and character of the public demand for it ...." E. BANField, The Democratic Muse 5 (1984). In questioning the role of government in assuring aesthetic experience, Banfield asks: How do the NEA panels of art experts determine what is art? Certainly, it is not the saine aesthetic experience when encounteriug Michelangelo's "Pieta" and the Piero Manzoni's bottled excrement, entitled "Artist's Shit?" Id. at 20. If the public interest in funding the arts is the exigency of the aesthetic experience, how does a government agency determine what art should be subsidized? Is it only that art which ehcits a romantic response from the audience? Can one include art that is purposely nonaesthetic and nihilistic in intent? Should such a determmation be elitist or populist in its approach? Banfield argues that even if such questions can be resolved, "[g]iving people pleasure has never been considered a proper function of the U.S. government" except as it might affect the "well-being of the collectivity ...." Id. at 205.

Proponents of the NEA would agree with Banfield's requirement that the government should be funding only those interests that affect the "well-being of the collectivity," but they would assert that the NEA is doing just that. "The arts are a means of personal fulfillment; aesthetic awareness in a mass society is a social determinant; the two are indivisible." M. STRAIGHT, supra note 201, at 64.

206. One of the most frequent criticisms of the NEA concerns its direct funding of individual artists. Banfield quotes the NEA purpose behind direct grants to provide "equal opportunity for the actor as well as the physicist, for the poet as well as the biochemist, for the sculptor as well as the mathematician" and dismisses the objective with the following rhetorical questions: "Why should career opportunities for artists be 'equal'-whatever it might mean-to those of scientists? Why not of, say, baseball players?" E. BANFIELD, supra note 205, at 69. Banfield also discusses congressional criticism of the program-the lack of auditing the artist's use of grant money and the effective gov- 
Artists also can receive government support in the form of more favorable tax policies. Current tax laws discriminate against artists in the areas of capital gains, ${ }^{207}$ deductible expenses and costs, ${ }^{208}$ and charitable

ernment censorship of traditional art due to the NEA panels' selections of avant-garde artists over traditional artists. He maintains that the government should not be in the business of picking and choosing artists to subsidize. Banfield relates the story of Michael Straight, the deputy chairman of the NEA from 1969-1978, who because of the chairman's illness, was left to sign off the list of awards approved by the NEA panel and by the National Council on the Arts. When reviewing the applicants' project accounts, Straight came across the following:

I will rent a ground level studio with high ceilings and a cement floor, adjacent to a lush meadow. And to this place I will bring Pigme, a full-grown sow (whom I have known since her ninth day), two female rabbits (who know each other and me), a buck (stranger), two ring-necked doves (strangers), a wooley monkey, Georgina (who knows me slightly).... We will all move together. ... Sometimes, we will leave our place and go together to another, or bring others to us. For these events, we will need a vehicle, preferably a motorbike with a large sidecar. Perhaps this communal way of life will be quite difficult. However, the educational value, for all of us will be extraordinary.

Id. at 19-20 (quoting from M. STRAIGHT, TwiGs FOR AN EAGLE'S NEST, supra note 201, at 130-31).

Straight refused to authorize this grant, as well as about twenty others. The chair was called in from her sickbed and the grants were made over Straight's objections. The rules were subsequently changed to avoid such crises in the future: Applicants were not to state what use they intended to make of the fellowship funds.

207. Artists cannot deduct the costs incurred when creating a work until the work produces income. 26 U.S.C.A. $\S \S 280$ (a), 263A(b)(1) (West Supp. 1989). Furthennore, an artist must prove that she engages in her craft for profit by showing a taxable gain in three out of five years, otherwise she is a hobbyist in the eyes of the I.R.S. and therefore not entitled to deduct any expenses of her business. See generally $\S 183(\mathrm{e})$.

Artists were not entitled to the preferential capital gains treatment afforded other merchants of property, including patent holders. 26 U.S.C. § 1221(3)(A) (1988). In Cantor, Tax Policy: Copyrights and Patents, 31 VILL. L. REv. 931 (1986), the author explores the utility-expression dichotouny used to justify differing treatment of copyright holders and patent holders in the area of capital gains. Prior to the repeal of the capital gains benefit in the Tax Reform Act of 1986 one who sold "capital assets" was permitted to deduct $60 \%$ of capital gains (capital gains being the sale price less cost incurred in acquiring or producing the item) derived from such sales and therefore was taxed on only $40 \%$ of the gain. 26 U.S.C. $\S 1202$ (repealed by Tax Reform Act, $\S 301$ ). Artists, however, as taxpayers whose "personal efforts created such property" were specifically excluded from enjoying this tax break. See id. §1221(3)(A). Patent holders, who also create "such property" through "personal efforts," were exempted from the exclusion and could take advantage of the $60 \%$ deduction of income. See id. § 1235 .

Tax incentives for inventors but not artists, both creators through personal efforts, crop up again and again throughout the tax code and reflect the assumption that technological ideas are indispensable to the advancement of society, and should be encouraged through the relaxation of its creator's tax burden, but those expressed in art are not. Prior to the repeal of the capital gains preference, lobbying efforts of friends of the arts resulted in proposals to extend the capital gains deduction to encourage and promote artistic creativity. See, e.g., H.R. 696, 93rd Cong., 1st Sess., 119 CONG. REC. 1865 (1973). No proposal was ever adopted.

208. An artist, like a manufacturer, must capitalize the costs incurred in producing the work rather than deducting costs as expenses in the year incurred. See 26 U.S.C. $\S 263 \mathrm{~A}(\mathrm{~b})(1)(1988)$; Temp. Treas. Reg. $\S 1.265 \mathrm{~A}-\mathrm{IT}(\mathrm{a})(5)(\mathrm{iii})$. As a result, costs may not be deducted until a work is sold. Prior to the Tax Reform Act of 1986, individuals who produced books, sound recordings, or similar property could deduct the costs of production in years in which they reasonably believed income would result and in proportion to the total anount expected to be generated over several years. See 26 U.S.C. $\S 280$ (a), (b) (repealed in 1986 by Tax Reform Act, § 263A). Since the repeal of $\S 280(a)$, artists must follow the extremely complex uniform capitalization rules. See id. 
contributions. ${ }^{209}$ The California droit de suite law, which serves as a tax upon subsequent purchases of an original work of art, by providing that an artist will receive additional payments each time his painting is sold at an increased value, could also prove to be a real benefit to artists like John. ${ }^{210}$

\section{Fair Use and the Artist}

Most comentators assume that the fair use doctrine benefits the pubhic, but not the artist. This assumption is based on the incorrect premise that artists create solely for financial reasons. It is true, of course, that all four artists may be financially injured by this doctrine. For Margo, since home videotaping is now considered a "fair use," 211 the value of her television scripts to an advertiser may be dimimished by the prospect of the viewer fast-forwarding his way through commercials. ${ }^{212}$ "Librarying" of televised movies by home users ultimately may have a detrimental effect

$\S 263 \mathrm{~A}(\mathrm{~b})(1)$. They must keep meticulous records of their outlays and allocate them among their works, if more than one "defer[s] deductions, increase[s] taxable income and ... create[s] an administrative nightmare." 4 Fed. Taxes (P-H) 16,747 (1988). Presently efforts are being made in the House to further amend the Code to allow free-lance artists, photographers, and writers to deduct expenses in the year incurred. H.R. 4333, 100th Cong., 2nd Sess., 134 CoNg. REC. H10,867-07 (1988).

209. Perhaps the most obvious injustice is exemplified by the rule that an artist may not deduct the fair market value of self-produced works donated to an institution while a more favorable tax position is given to the donating collector, who receives a hefty charitable contribution deduction. 26 U.S.C. $\$ 170$ (e) (1988). The creator may deduct merely the cost of the canvas, pigments, clay, etc. (Note that an artist's estate, like that of anyone else, is taxed on the full market value of works that are in her possession at the time of her death. See id. $\S 2031(\mathrm{a})$.) For a full analysis of the effect on the mcentive of the individual to create and donate, and on the collections of the nation's museums, see Note, Changing I.R.C. $\$ 170(e)(1)(A)$ : For Art's Sake, 37 CASE W. REs. 536, 547.49 (1987). Legislation aimed at correcting this inequity has been proposed in the National Heritage Resources Act, H.R. 3087, 99th Cong., 1st Sess., 131 CoNG. REC. E3564 (July 26, 1985), but to date no change has been made. For a comprehensive discussion of the new Tax Act and artists, see Rowe, New Tax Act and Individual Artists, 11 ColuM. J.L. \& ARTs 669 (1987).

210. For a description of the droit de suite, see supra notes 102-11 and accompanying text.

211. See supra notes $49-51$ and aceompanying text.

212. In Sony Corp. of Am. v. Universal City Studios, 464 U.S. 417 (1984), the Supreme Court accepted the finding of the district court that time-shifting would not affect rerun audiences and rejected arguments that it would harm the theatre audiences and video rentals of motion pictures, $i d$. at $452-53$, and that advertisers might withdraw advertising support from taped programs because viewers would fast-forward and avoid commercials. With respect to the last argument, the majority relied on the state-of-art of videotape recorders at the time of the decision. Most machines blanked the screens for fast-forwarding, so that viewers would have to guess when commercials ended. Id. at 453 n.36. However, almost all machines manufactured more recently allow viewers to view the commercial during fast-forwarding to deternine when the program begins and to fast-forward without leaving their chairs. Thus, it is highly likely that a much higher percentage of viewers today do fast-forward through commercials. The Court has rejeeted a motion for reconsideration, based on this aspect of the new technology. Sony Corp. of Am. v. Universal City Studios, 465 U.S. 1112 (1984); see also 3 M. NIMMER \& D. NIMMER, supra note 2, § 13.05[F] n.172. 
on the motion picture industry and on her income. ${ }^{213}$ David's non-fiction work, such as his biography of President Nixon, may be subject to a first amendment type of fair use defense. ${ }^{214}$ If most newsworthy portions of his work are reproduced in commercial magazines, then the market for his book could decline significantly. Susan probably will be the most affected by the fair use doctrine. Simce other teachers may use her poetry in their classes and other artists may borrow from her imagery, the sales of her poetry books may be hurt.

Despite the financial losses it may impose, the fair use doctrine actually can help Susan, David, and John achieve their most important goals. David, the political "think-tank" writer, wants as many people as possible to read his work, so that he will wim more converts to his views. $\mathrm{He}$ will welcome excerpts of his writing in newspapers, magazine articles and columns, and favorable book reviews. ${ }^{215}$ Susan would like to move up the academic ladder to a more prestigious institution; use of her poems by other professors will add to her reputation. ${ }^{216}$ Although Jolin paints

213. The Sony Court, 464 U.S. at $443-56$, restricted its holding to time-shifting videotaping, and most commentators interpret the opinion as assuming that "librarying" is not fair use. See, e.g., Fisher, supra note 9, at 1665 n.23, ("All parties and all members of the Court assumed, at least for the sake of argument, that librarying is not a fair use and that therefore a substantial number of VCR owners often violate the copyriglit law.") However, the average citizen, who has now read that videotaping is "legal," is not likely to make such fine distimctions.

The Sony majority ducked the "librarying" issue by empliasizing that it "need not explore all the different potential uses of the machine." 464 U.S. at 442 (empliasis in original). The dissent, in contrast, explicitly discussed librarying, noting that Sony's advertisements actually promoted the practice. Id. at 458-59 (Blackmun, J., dissenting). It also cited findings from the district court that librarying was substantial-both sides' snrveys showed the average Betamax user owned between 25 and 32 tapes and that at least $40 \%$ of users planned to view their tapes more than once. Id. at 483 n.35.

The harm to the market for motion pictures from librarying should be obvious. Videotapes that are capable of recording six liours of programming (approximately tlree motion pictures) currently are available for three to four dollars, wlich is only slightly higler than the two to three dollars it costs to rent a video movie and lower than the six dollars it costs to see a movie in a theatre. In addition to the price advantage, "librarying" offers the viewer the advantage of convenience-sle can watcl the program whenever she wishes.

It is true that the above analysis applies primarily to motion pictures. However, the rerun audience for a popular television series also will be diminislied if viewers library individual segments of that program (I have friends who have taped for permanent use over 60 "M.A.S.H." programs). Residuals are a primary source of income in the television industry. See infra note 221.

214. See infra note 252.

215. Book reviews are a commonly cited example of fair use. See 3 M. N1MMER \& D. N1MMER, supra note $2, \S 13.05$.

216. One commentator has recognized that many academics welcome widespread dissemination of their work, acknowledging "creator[ ] desire[s] for wide and nntrammeled dissemination and circulation of his writings, regardless of financial royalties. This ... motivation is a key to the bulk of current non-profit intellectual creativity." Rosenfeld, The Constitutional Dimension of "Fair Use" in Copyright Law, 50 Notre DAME LAw. 790, 806 (1975). Most commentators continue to assume financial motivation is the sole incentive for all artists, including educators. See, e.g., Fisher, supra note 9 , at $1700-05$ (because works of art are "public goods," there is risk they will not be created 
primarily for self-fulfillment, he also wants appreciative audiences to share his vision of art, and he recognizes that reproductions of his work will allow him to reach many people who cannot view the original.

The people who are actually most likely to object to "fair use" in an artistic or educational context are not the artists themselves but rather their publishers. ${ }^{217}$ Susan and David may be willing to lose potential sales of their books, since they only receive partial royalties, and the benefits in increased readership and reputation outweigh their losses. The publislier's interest, however, is solely monetary. Obviously this interest cannot be ignored; if publishers decided that any work subject to a successful fair use defense would be too risky to print, both the artists and the public interest would suffer. But the publisher's interest should be recognized as only one factor in evaluating this doctrine-a factor that does not necessarily coincide with the artist's interest.

\section{Duration Rules and the Artist}

John, the struggling painter, is the type of artist who probably will be injured most by the limited duration of copyright protection. Many paintings dramatically increase im value years after their owner's demise. 218 For example, Renoir sold one of his paintings in the 1870s for $\$ 85$; in 1915 it sold for $\$ 200,000.219$ A separate problem is the fact that many painters, unlike writers, usually liave only one product to sell-a single painting as opposed to multiple copies of books. Thus even in his lifetime, an artist may be forced to sell a painting for a small amount of money, yet he receives no additional compensation when its value is enhanced.

Susan's reputation as a poet may increase with time; however the imcome froin her poetry probably will not vary significantly because the market for poetry is never substantial. Even poems by well-known poets are worth $\$ 1000$, at best, upon publication. ${ }^{220}$ Thus, to the extent that Susan is motivated by an interest in her heirs' welfare, her concern about the durational protection will be minimal. And the contemporary value of David's work on politics indicates that its value, although not as

because of lack of monetary incentive); Gordon, supra note 9, at 1602-05 ("ultimate goal is not author remuneration, however, but advancement and dissemination of culture and knowledge"); Sinclair, supra note 9, at 288-94 (arguing that none of the noneconomic goals of a copyright system provide an adequate justification for such a system).

217. Breyer is one of the few commentators to emphasize the role of the publisher-often the true copyright holder-in copyright theory. Breyer, supra note 11, at 293-321.

218. See generally THE ECONOMICS OF TASTE, supra note 83.

219. See F. DURET-RoBERT, supra note 131, at 306.

220. See supra notes $176-80$ and accompanying text. 
ephemeral as Margo's, ${ }^{221}$ will be recognized primarily during his lifetime. Therefore, the duration rule will not affect the interests of these three artists significantly.

\section{E. Moral Rights and the Artist}

All four artists would benefit substantially from the incorporation of moral rights into current copyright law. John's primary concern will be that his paintings are not destroyed or distorted by subsequent purchasers. Moral rights doctrine would allow him to require a museum to display his work in a setting he that considers appropriate and preserve the work from damage by too much sunlight.222 This doctrine also would prevent use or reproduction of his work in a manner he considers inappropriate-for an example in a commercial setting, such as the use of a reproduction of a painting like "Whistler's Mother" to sell rocking chairs. ${ }^{223}$ The knowledge that his works are protected by moral rights even after he has sold them may be of greater value to John than the relatively small amount he will realize from an actual sale.

Susan, whose income depends primarily upon her academic status, also has a high stake in ensuring that her works will not be distorted and that she will receive full credit as the author of her work. ${ }^{224}$ Her right to prevent the unauthorized use of her name also means that she may be able to block the distribution of overly simphistic outhines of her writing, which would injure her reputation. ${ }^{225}$

221. Soine films, such as "Gone With The Wind," do increase in value over the years; however, they are the exception. Additionally, royalties from reruns of popular television shows can provide continuing financial support to the writer, possibly beyond the author's lifetime.

222. These are examples of the right of integrity. See, e.g., Merryman, supra note 19, at 1027-49. It is true that John's moral rights inay conflict with the inuseum's property rights. However, since the moral rights doctrine means that John has never really given up his interest in his painting, his rights should prevail.

223. A Umited States court rejected an attempt by Soviet composers to use an analogous theory in Shostakovich v. Twentieth Century-Fox Film Corp., 196 Misc. 67, 80 N.Y.S.2d 575 (Sup. Ct. 1948). The composers objected to the use of their inusic in an anti-Soviet filn entitled "The Iron Curtain." They argued that the use implied that they were disloyal to their country, but the court found that since the works were in the public domain, there was no implication of endorsement. Id. at 68,80 N.Y.S.2d at 578 . This conclusion completely ignored the fact that the average citizen would be unaware of the concept of public domain and assume that the composers authorized use of their music.

224. This is an example of the right of pateruity. DaSilva, supra note 19, at 26-30. This right also has been rejected by a court in Vargas v. Esquire, Inc., 164 F.2d 522, 526 (7th Cir. 1947).

225. This is another example of the right of integrity. In an analogous case, a California state court agreed to enjoin publication of classroom notes of a UCLA anthropology professor, on the grounds of common law copyright infringement and invasion of privacy. Williams v. Weisser, 273 Cal. App. 2d 726, 742, 78 Cal. Rptr. 542, 551 (1969). The court acknowledged the possibility that the teacher's professional standing could be jeopardized by publication of the notes, since they contained important omissions on the subject and other professors might believe he authorized the prod- 
David, much to his present chagrin, was once a student radical and the author of several student newspaper articles and pamphlets that he would now prefer to see removed from the market. The moral right of retraction might give him this opportunity. ${ }^{226}$ Although Margo's interest in moral rights may seem the least significant, she has a strong interest in ensuring that she receive proper screen credit for her work. ${ }^{227}$ She has professional pride in her scripts, and she would not want to see them altered beyond recognition by subsequent rewrites.

As these examples illustrate, many artists care more about protection of the fundamental integrity of their work than the financial gain the work will realize. This concern may mean that moral rights actually provide greater incentive for creation of artistic works than copyright protection. Without such protection, artists who are motivated by nonfinancial considerations may be reluctant to share their works with the public. Ideally, then, this doctrine can benefit both the artist and the public-for example, it is to most people's benefit that an original sculpture not be altered. There are situations, however, in which the two interests will conflict. David may want his earlier works destroyed, the public may want to read them. I will discuss the obstacles moral rights theory poses to the public interest in a later section of this Article.228

\section{RethinkING the Public Interest}

\section{A. Two Concepts of the Public Interest}

It generally is acknowledged that the widespread availability of copyrighted work is necessary to serve the "public interest."229 This term seldom is defined, however, and its meaning ultimately depends on the speaker's assumptions about the nature of the "public." Contempo-

uct. Id. Arguably, Susan can rely on trademark law on theories of unfair competition to prevent the use of her name, but these theories are not always successful. See supra notes 101-02.

226. Merryman, supra uote 19 , at 1028 . However, the moral right of retraction is seldom used and is very limited. See infra note 268 and accompanying text.

227. Questions of who receives screen credit for motion pictures may not seem earthshaking to the average person, but they are of paramount importance in Hollywood and the subject of a great deal of litigation. See generally Berman \& Rosenthal, Screen Credit and the Law, 9 UCLA L. Rev. 156,185 (1962) ('[t]o one who 'must live by getting known to the public,' ... screen credit is of the utmost concern") (footnotes ommitted); WRITER's GUILD AGREEMENT, supra note 172 (contains extensive regulations regarding screen credit).

228. See infra notes 261-68 and accompanying text.

229. E.g., 3 M. NIMMER \& D. NIMMER, supra note 2, § 13.05[A], at $13-72$ (public benefit); Gordon, supra note 9, at 1601 (market approach provides a guide both to where the public interest lies and to identify those occasions in which the court may "substitute its evaluation of the public interest"); Sinclair, supra note 9, at 291-92 (fair use doctrine used to balance societal value in second use against harm to plaintiff); Walker, supra note 9, at 754 (public interest is the underlying basis for any fair use decision). 
rary liberal theory regards the "public" as a Hobbesian collection of autonomous individuals, each actmg out of self-interest. ${ }^{230}$ Economists who subscribe to this view believe that the purpose of intellectual property law is to facilitate transactions between the copyright holder and a large number of potential recipients. ${ }^{231}$ Since most copyriglited materials are public goods, one-on-one transactions are often not efficient, ${ }^{232}$ and therefore variations froin ordinary property and contract law are necessary to ensure widespread availability to the largest possible number of individuals.

The altruistic aspects of intellectual property theory suggest a fundamentally different concept of the public interest. ${ }^{233}$ The "public" also can be understood as an interdependent community with certain coininon interests that affect all its inembers. ${ }^{234}$ Under this viewpoint, even individuals who are not direct recipients of artistic work benefit from its availability to society, just as free public education does more for a coininunity than servimg the individual needs of parents of school-age children. ${ }^{235}$

Since abohshing property rights in their work would be unreahstic and unfair to today's artists, it is vitally important that we develop a definition of "public interest" that provides guidelines as to when limita-

230. See generally T. HobBES, LEviathaN 63-66, 104-10 (Everyman's Library ed. 1983). For a fascinating argument that Hobbes has been mischaracterized and oversimplified in traditional jurisprudence, see Boyle, Thomas Hobbes and the Invented Tradition of Positivism: Reflections on Language, Power, and Essentialism, 135 U. PA. L. REv. 383 (1987).

231. See Gordon, supra note 9, at 1605-10.

232. Id. at 1610-14. Gordon acknowledges there also will be situations where "conditions of perfect competition" do not exist. One such situation is a transaction where the resource user's activities translate into " "external benefits' not reflected in his income." Id. at 1607. This resembles the community interest model.

233. E.g., Fisher, supra note 9, at 1744-80 (considering a system that substitutes the goal of " [a] just and attractive intellectual culture" for market efficiency); see also Simclair, supra note 9, at 291-93.

234. The concept of community has been much discussed in legal, political, and philosophical literature. As one student commentator notes, "in contrast to liberalism's individualist portrayal of politics, communitarianism emphasizes the classical conception of a political community animated by a shared conception of the good." Note, A Communitarian Defense of Group Libel Laws, 101 HARV. L. Rev. 682 (1988); see also Karst, Equality and Community: Lessons from the Civil Rights Era, 56 NotRe Dame LAW. 183, 186 (1980) ("[T] he traditional forms of community—the village, the guild, the church, the city neighborhood, the ethnic group, even the family—have been eroded by a tide of individualism that has been flowing steadily for some three hundred years."); Michelman, The Supreme Court, 1985 Term-Foreword: Traces of Self-Government, 100 HARv. L. REv. 4, 56 (1985) ('The conflict between . . 'individual' and 'community' self-determination ... reflect a characteristic tension in the general concept of self government.").

235. Although the Supreme Court has declined to recognize public education as a fundamental right, it has acknowledged that "education is perhaps the most imiportant function of state and local governments... . It is required in the performance of our most basic public responsibilities ... It is the very foundation of good citizenship." Brown v. Board of Educ., 347 U.S. 483, 493 (1954). 
tions on copyright are appropriate. I beheve the concept of community is central to our understanding of the public interest. A sense of community adds to our personal identity, and to our fulfillment as complete human beings. ${ }^{236}$ Art serves this sense of community in a variety of ways: ${ }^{237}$ It enriches us with beauty, morahty, history, even with that elusive commodity-"truth". ${ }^{238}$

In the context of the fair use defense, a communitarian-based definition of the "public interest" not only is desirable for philosophical reasons, it also is the only one that makes sense. There is no reason for the fair use defense to exist if all we mean by the "public interest" is a collection of autononous individuals. The copyright system in its non-limited form is an adequate meclianism for serving individual personal needs; an economic analysis would not indicate that it is desirable to favor an individual copyriglit user over an individual copyright holder. ${ }^{239}$ When commentators give examples of situations in which the fair use defense is appropriate, they invariably cite areas such as educational uses, news reporting, and book reviews in which the benefit to the community as a whole is apparent. ${ }^{240}$

The proper perspective on the fair use defense focuses on the extent that the work contributes to the comnion goals of the community. The greater the relationship of the work of art to the shared values of the

236. The idea of interdependence between the individual and the community has become a central theme of feminist jurisprudence. See generally Bender, supra note 15, at 28-30. In C. GILLIgan, In a Different Voice: Psychological Theory and Women's Development 30 (1982), Carol Gilligan explains the image an eleven year old girl has of human relationships: "Her world is a world of relationships and psychological truths where an awareness of the connection between people gives rise to a recognition of responsibility for one another, a perception of the need for response."

237. Albert Elsen suggests that "[o]ften it is art that is a powerful force for uniting a society." Elsen, Introduction: Why Do We Care About Art, 27 Hastivgs L.J. 951,952 (1976).

238. In Keat's classic words:

When old age shall this generation waste,

Thou shalt remain, in inidst of other woe

Than ours, a friend to man, to whom thou say'st

"Beauty is truth, truth beauty,"- that is all

Ye know on earth, and all ye need to know.

J. Keats, Ode on a Grecian Urn, in The POETICAL WORKS OF John KeATS 233, 234 (Oxford ed. 1946).

239. It is a fundamental assumption of liberal analysis that no one individual's preference should be given priority over another's.

240. See, e.g., 3 M. NimMER \& D. NimMER, supra note 2, § 13.05[A]; Gordon, supra note 9, at 1633 (arguing that fair use should be allowed because the owners are unlikely to license the work themselves). The actual examples given in the fair use section of the Copyright Act also all pertain to the common good of the commumity-the Act lists as examples of proper fair use "purposes such as criticism, comment, news reporting, teaching (including multiple copies for classroom use), scholarship, or research." 17 U.S.C. $\$ 107$ (1988). 
community, the greater the need for widespread availability. ${ }^{241}$ This approach also can be put in economic terms by using the concept of externalities. When a work provides significant external benefits to society beyond the benefits to its user, fair use is appropriate. ${ }^{242}$

In order to accomphish this result, courts need to abandon the current approach to fair use analysis, an emphasis on the fourth prong of the test-the effect of the use on the work's market as the most important factor. ${ }^{243}$ Instead, courts need to rediscover the first two statutory factors of the defense- (1) the purpose and character of the use and (2) the nature of the copyrighted work. 244 Each of these factors can be vitally important in determining whether a given use serves a shared community interest.

241. I have deliberately made this standard flexible with respect to what type of work contributes to the common good of the community. In contrast, William Fisher offers a rich and detailed analysis of a utopian social order and an explanation as to how fair use can be used to advance his vision. Fisher, supra note 9, at 1744-79. He suggests that "[t]he good life is a life of self-determination, commitment, moderate risk, and meaningful work." Id. at 1746 (footnote omitted). After developing this concept of the good life, he "considers how a judge who had time on his hands and extensive access to information, who knew that other courts would adhere to his rulings, and who fully shared the utopian vision [previously] advanced . . . might rebuild the fair use doctrine." Id. at 1766.

Fisher's approach contributes much to fair use doctrine and his vision of the good life has many positive aspects. However, I am concerned that it would not be viable as an approach for resolving actual fair use cases. As Fisher himself acknowledges, to use this approach a judge must have "time on his hands" (a very rare commodity in our overcrowded court system) and more importantly must share Fisher's own idea of utopia. My more open-ended standard leaves a judge more flexibility. Of course, flexibility carries its own dangers-allowing a judge to impose her own vision of community, which may differ significantly from my own, could be troubling. However, I think the proper emphasis is on shared values. This emphasis at least provides some guidelines-a judge must look for a work that contributes to the community as a whole. The use that community may make of the work may or may not conform to the judge's vision of a utopian community, but the judge will not be called upon to make that decision. For example, it is likely that both a conservative and a liberal judge would argue that previously unavailable information about political conditions in Nicaragua would contribute something to the community as a whole, because it will stimulate political debate. The conservative may hope that the community will use the information to determine that Contra aid is desirable, the liberal may desire the opposite result, but both can agree as to the desirability of access to the information.

242. Gordon, in her discussion of externalities, comes close to recoguizing a communal interest in certain copyrighted works. Gordon, supra note 9, at 1630-32. She notes that "all of society benefits from having an educated citizenry and from advances in knowledge," $i d$. at 1630, and suggests that when a first amendment interest is at stake, the market system may not function in a way which best serves the citizenry, $i d$. at 1631 . However, the benefits to society which externalities provide are but one aspect of her proposed fair use test. In contrast, Cirace's discussion of consumption externalities focus on their negative aspects. See Cirace, supra note 9, at 671-78.

243. See, e.g., Sony Corp. of Am. v. Universal City Studios, 464 U.S. 417, 450 (1984) (respondents failed to show that sale of video tape recorders would undermine the market for the copyright material); Harper \& Row, Publishers v. Nation Enters., 471 U.S. 539, 545-56, 569 (1985) (holding that publication of former President Ford's memoirs not fair use on the basis of the effect on market value of material). The fourth prong appears in 17 U.S.C. $\$ 107(4)$ (1988).

244. 17 U.S.C. $\S 107(2)(1)(d)$ (1988). 
One immediate objection that could be raised to a community-interest fair use "test" is that it will be impossible to apply or be tinged with elitism and political opinion. 245 An mquiry into a work's value to the community necessarily would rely on the value of the work itself; yet it has become a copyright clichè that the legal system is incapable of determining a work's imtrinsic merit. As Justice Holmes warned, "It would be a dangerous undertaking for persons trained only to the law to constitute themselves final judges of the worth of pictorial illustrations, outside of the narrowest and most obvious limits."246

Nevertheless, the fair use defense already requires an inquiry into the nature of the copyrighted work. ${ }^{247}$ In this respect, the community interest standard does not add anything new; it only gives us guidelines about how to conduct that inquiry. Justice Holmes was writing about situations in which a judge must decide whether or not to give copyright protection to the original creator of a work, ${ }^{248}$ and his words are certainly true in that context. Different considerations are appropriate when a judge inust decide whether or not to permit an infringer to copy protected work. It should be possible in most cases to determine whether a work of art is very iniportant or only marginally important to the community. ${ }^{249}$

All intellectual property can be categorized roughly as work that has either political, educational, aesthetic, or entertainnent value, or as work that has value in several of these contexts. 250 Arguably, political information, which contributes to the debate about the very nature of our government and its policies, is of the greatest value to a comnuunity. This is the explicit assumption the Supreme Court repeatedly has applied

245. As such, it is subject to criticism as glorifying and preserving "bourgeois culture" at the expense of a true cultural revolution. See H. MARCuSE, Counter Revolution and Revolt 79 128 (1972). Marcuse argues that the traditional "aesthetic form" of art transforms reality and promotes a false vision of our social order. Id. at 81-87.

246. Bleistein v. Donaldson Lithographing Co., 188 U.S. 239, 251 (1903).

247. 17 U.S.C. $\S 107(2)$ (1988).

248. The Bleistein case considered the issue of whether chromolithographs that were circus advertisements could be copyrighted. Judge Holmes emphatically stated that the requirement of originality as a prerequisite for copyright protection does not go to the merits of the work or to the fact that the chromolithographs were advertisements. Bleistein, 188 U.S. at 250-51.

249. The idea of allowing judges to make a determination regarding the community interest may be troubling to many readers. It might be worthwhile to consider other alternatives, such as a panel of community leaders. These leaders also could be expert witnesses in a conventional trial.

250. One can think of many borderline cases: Was "Roe v. Wade" (NBC television broadcast, May 15, 1989) a made-for-television movie about the Supreme Court's abortion decision entertainment or political information? Is "Sesame Street" edueational or entertainment? Nevertheless, most intellectual property can be so categorized. 
in giving the greatest first amendment protection to political speech. ${ }^{251}$ If it is correct, then information serving this first amendment interest should constitute the most ideal example of "fair use."252 For example,

251. E.g., First Nat'1 Bank v. Bellotti, 435 U.S. 765, 776-77 (1978) (striking statute that forbids banks and corporations to publicize views regarding referendum); Roth v. United States, 354 U.S. 476, 484 (1957) (obscenity statute not prohibited by first amendinent); Whitney v. California, 274 U.S. 357, 374-78 (1927) (Brandeis, J., concurring) (upholding California Criminal Syndicatism Act). Justice Black wrote in Mills v. Alabama that "[w]hatever differences may exist about interpretations of the First Amendinent, there is practically universal agreement that a major purpose of that Amendinent was to protect the frec discussion of governmental affairs." 384 U.S. 214, 218 (1966). Some coininentators have even suggested that only political or "public" speech deserves first amendment protection. See, e.g., Bork, Neutral Principles and Some First Amendment Problems, 47 IND. L.J. 1, $24-28$ (1971).

252. Several commentators have suggested that there is an inherent conflict between the first amendment, which prohibits laws abridging speech, and copyright law, which restricts speech by creating a property interest in a creator's work. E.g., Denicola, supra note 9, at 284-86 ("[T]he origins of copyright law reveal ... the potential conflict between property rights in intellectual creations and freedom of expression. ... [F]irst amendinent values have been incorporated into our legal system from its inception. The problem is to determine whether a statutory schenne that recognizes property rights in 'original works of authorship' can operate in a fashion consistent with these fundamental values."); Goldstein, supra note 9, at 984 ("[C]opyright persists in its potential for conflict with the first amendinent. Dispensed by the government, copyright still constitutes the grant of a monopoly over expression."); Nimmer, supra note 9, at 1181 (There is a largely ignored paradox in copyright law: "The first amendeinent tells us that "Congress shall nake no law ... abridging the freedom of speech, or of the press.' Does not the Copyright Act fly directly in the face of that coinunand? Is it not precisely a 'law' Inade by Congress which abridges the 'freedoin of speech' and 'of the press' in that it punishes expressions by speech and press when such expressions consist of the unauthorized use of material proteeted by copyright?'); CoInnent, Copyright and the First Amendment: Where Lies The Public Interest?, 59 TUL. L. REv. 135, 156-60 (1984) (proposing a fair use test based on the necessity of borrowing copyright expression). Melville Ninmer argued this conflict was at least partially resolved by the idea/expression dichotony. Niminer, supra note 9 , at 1189-93. This doctrine, was a part of the common law and was codified in the Copyright Act, which states that "[i]n no case does copyright protection for an original work of authorship extend to any idea, procedure, process, system, inethod of operation, concept, principle, or discovery." 17 U.S.C. $\S 102$ (1988). Because of this doctrine, to use Ninnner's analogy, the public will be exposed to the thoughts of such diverse thinkers as Eldridge Cleaver and William F. Buckley-their ideas are "free as air." Ninnner, supra note 9, at 1191-92. However, the expressions of their ideas, which are found in their books, cannot be reproduced by an infringer. For a criticism of this viewpoint, see Libott, supra note 139.

Most courts accept the proposition that the idea/expression dichotony prevents a conflict of interest between the first annendinent and copyright law, but soine cominentators, most importantly Nimmer and Robert Denicola, argue that there are situations in which this distinction does not work. See Denicola, supra note 9, at 292-93; Nimmer, supra note 9, at 1197-1200. The basic problem Niminer identifies is that there are situations in which it is inpossible to effectively separate a work's "idea" from its "expression" and situations in which "the 'idea' of a work contributes almost nothing to the democratic dialogue, and it is only its expression which is meaningful." Ninmer, supra note 9 , at 1197 .

If it is true that the idea/expression distinction does not always protect the comınunity interest in receiving information, what is the reinedy? The obvious possibility is the fair use defense, which arguably serves the public interest. Niminer, Denicola and others believe that fair use is not the answer because courts concentrate on the harm to the defendant's market, not the public's need for political information. They argue that courts must recognize a separate first amendment defense to copyright infringement. However, to date courts have explicitly or implicitly rejected this theory. 
photographs of the Vietnam War's My Lai massacre provided a universal benefit by increasing awareness of and stimulating debate on the country's military pohicy. ${ }^{253}$ Educational and artistic works similarly satisfy important public needs. On the other hand, the widespread availability of videotapes of "Gilligan's Island" enhances the community's interest

E.g., Harper \& Row, Publishers v. Nation Enters., 471 U.S. 539 (1985) (discussed infra note 256); Walt Disney Prods. v. Air Pirates, 581 F.2d 751, 758-59 (9th Cir. 1978), cert. denied, 439 U.S. 1132 (1979); Sid \& Marty Krofft Television Prods. v. McDonald's Corp., 562 F.2d 1157, 1169-72 (9th Cir. 1977); Meeropol v. Nizer, 560 F.2d 1061 (2d Cir. 1977), cert. denied, 434 U.S. 1013 (1978); Wainwright See., Inc. v. Wall Street Transcript Corp., 558 F.2d 91, 97 (2d. Cir. 1977), cert. denied, 434 U.S. 1014 (1978); Time, Inc. v. Bernard Geis Assocs., 293 F. Supp. 130 (S.D.N.Y. 1968).

Only one trial court actually has recognized a separate first amendment defense, Trianglc Publications v. Knight-Ridder Newspapers, 445 F. Supp. 875, $881-84$ (S.D. Fla. 1978). However, in affirming the lower court's decision, the Fifth Circuit found that defendant's copying of plaintiff's work was covered by the fair use defense, since there was only a de minimis effect on the commercial value of plaintiff's copyright. It expressly declined to consider the first annendment issue. Triangle Publications v. Knight-Ridder Newspapers, 626 F.2d 1171, 1178 (5th Cir. 1980). In his concurrence, Judge Tate stated that he believed "under limited circumstances, a First Amendment privilege may, and should exist where utilization of the copyrighted expression is necessary for the purpose of conveying thoughts or expressions." Id. at 1184 (Tate, J., concurring).

253. Ninner first introduced the hypothetical of the My Lai photographs in his law review article on the first amendment and copyright, stating that "[n]o amount of words describing the 'idea' of the massacre could substitute for the public insight gained through the photographs. The photographic expression, not merely the idea, became essential if the public was to fully understand what occurred in that tragic episode." Nimmer, supra note 9, at 1197. Since then, the hypothetical has been cited repeatedly as if it were a real case and remains a classic example of the need for a recognition of the first amendment interests of the public. Nimmer confines his examples to news photographs and news films, Nimmer, supra note 9, at 1197-98, but I believe there are situations in which the community should hear a person's actual spoken words to understand their political implications. Sanitized or written versions of the Watergate tapes would not have allowed the public to grasp their full implications. To illustrate, a sanitized transcript of portions of the tapes ("expletives have been omitted in the interest of good taste") was submitted by former President Richard M. Nixon to the House Judiciary Committee:

President: How much of a crisis? . . [E]verything is a crisis. (expletive deleted) it is a terrible lousy thing - it will remain a crisis among the upper intellectual types, the soft heads, our own, too-Republicans-and the Democrats and the rest.

Submission of Recorded Presidential Conversations to the Committee on the Judiciary of the House of Representatives by President Richard Nixon, 93d Cong., 2d Sess. 144 (Apr. 30, 1974). Compare the sanitized version to the Committee's verbatim transcription of the tapes:

President: How much of a crisis? I mean, it'll be, it'll be in a newspaper (unitelligible) but the point is that everything is a crisis. I mean, Christ, we've had-screw around with this thing for a while (unintelligible) it'll be mainly a crisis among the upper intellectual types, the ass holes, you know, the

Dean: That's right.

Nixon: soft heads, soft-our own, too-Republicans, Democrats and the rest. Averagc people won't think it is much of a crisis unless it affects thenn. But it'll go on and on and on.

Hearings Before the Comm. on the Judiciary, House of Representatives: Transcripts of Eight Recorded Presidential Conversations, 93rd Cong., 2d Sess. 70 (1974).

A paraphrase would fail to capture the unpresidential desperation of the following statement:

President: ... I don't give a shit what happens. I want you all to stonewall it, let them plead the Fifth Amendment, cover-up or anything else, if it'll save ... the plan.

Id. at 183 . 
only in the sense that a large number of individuals may want to own these videotapes. Thus the Supreme Court was certainly wrong in holding that videotaping of purely entertaining television programs constitutes fair use, ${ }^{254}$ and the Court used the wrong analysis in determining that a news magazine's appropriation of a former president's memoirs was not fair use. ${ }^{255}$ Until courts abandon their single-minded focus on

254. Sony Corp. of Am. v. Universal City Studios, 464 U.S. 417 (1984) (discussed supra note 49). The Sony decision has been severely criticized. See, e.g., 3 M. NIMMER \& D. NimMER, supra note $2, \S 13.05[\mathrm{~F}][\mathrm{b}]$ ("[T]he Sony decision does not speak to the propriety of off-the-air taping of programs from pay or cable television systems. ... [I]t may be expected that the off-the-air taping issue will return to the courts . ..."); Fisher, supra note 9, at 1784-89 (conciuding decision rejecting fair use is more consistent with proposed utopian program); Note, "Fair Use" on Videotape, supra note 50 (criticizing district court opinion followed by Supreme Court majority). The inajority opinion's discussion of the first two factors of fair use virtually avoided any consideration of the community interest (or lack thereof). Justice Stevens stated that with regard to the first factor, the fact that the use was noncommercial was significant. Sony, 464 U.S. at 449 . In contrast, the dissent's analysis of the first factor emphasized that the use was not productive and stated that fair use is usually only found when the infringer's use is a productive one, id. at 478-89 (Blackmun, J., dissenting)-an analysis much more consistent with the community interest.

The inajority opinion cavalierly dismissed the second factor-the nature of the work-by sinply stating that the work was free to the viewer. $I d$. at 449-50. It briefly acknowledged the copying was complete, which cut against a fair use finding under the third factor, id. at 450 , and went on to the fourth factor-the harm to the plaintiff's market. This factor was dispositive in the Court's decision. See supra notes 49-53 and accompanying text.

255. Harper \& Row, Publishers v. Nation Enters., 557 F. Supp. 1067, 1072 (S.D.N.Y. 1987), rev'd in part, 723 F.2d 195 (2d Cir. 1983), aff'd in part, rev'd in part, 471 U.S. 539 (1985). In this case, former President Gerald Ford contracted with Harper \& Row to write a book about his White House experiences, including a coinplete account of his decision to pardon former President Richard Nixon for his Watergate activities. The terms of the contract explicitly stated that Mr. Ford was not to disclose any "unique information" regarding his meinoirs to the media in any fashion. 723 F.2d at 197-98. Once the book was completed, Harper \& Row licensed to Time magazine the right to publish excerpts from the forthcoining book in its April 23, 1979 issue. However, in late March 1979, someone gave a copy of the manuscript to the editor of the Nation. On April 3, 1979, the Nation published an issue which contained an article based on the Ford memoirs. Id. The article was approximately 2250 words long. Although most of the article was a suminary of Ford's book, at least 300 words concerning Ford's actions and conversations regarding the Watergate pardon were taken verbatim froin the unpublished manuscript. Id. at 206. Time subsequently cancelled its scheduled article and refused to pay Ford's publisher. Id. at 198-99.

The District Court for the Southern District of New York determined that the Nation's action constituted a copyright infringement. The Court of Appeals for the Second Circuit reversed, holding that the Nation's articles constituted a "fair use" of Ford's material. In a 6 to 3 decision, the Supreme Court reversed and remanded, expressly overruling the "fair use" finding. 471 U.S. 539, 542, 569 (1985).

Justice O'Connor's majority opinion discusses the incentive purpose of the Copyright Act, criticizing the Second Circuit for "insufficient deference" to its "scheme ... [of] fostering the original works that provide the seed and substance of this harvest." Id. at 545-46. The heart of her decision focused on the $300-400$ words that the Nation admittedly copied, id. at 548-49, and the inapplicability of the fair use defense to this copying, id. at 560-69. After apparently creating a presumption that an author's first publication rights outweigh a fair use clain-Justice O'Connor writes: “Under ordinary circumstances, the author's right to control the first public appearance of his undisseminated expression will outweigh a clain of fair use," id. at 555-the opinion addressed the first amendinent arguments advanced by the appellate court. She argued that "[ $t]$ he promise of copyright 
the damage to the marketplace and consider instead the needs of the community, the fair use defense will continue to be misapplied.

Another major objection to a conımunity-based fair use standard would be that it would penalize the very artists who produce the most valuable and important work and eventually result in severely reduced production of such work. ${ }^{256}$ This objection is only convincing if one accepts the theory that all artists create, solely for money. As I have discussed, this theory is certainly not true for all artists, and probably not true for the majority. ${ }^{257}$ Moreover, many artists, such as the poet-aca-

would be an empty one if it could be avoided merely by dubbing the infringement a fair use 'news report' of the book." Id. at 557. Accepting a first amendment theory in this case would "effectively destroy any expectation of copyright protection in the work of a public figure." Id. The first amendment was adequately served, she concluded, by the idea/expression dichotomy.

The opmion, which accepts the pure marketplace ideology regarding the copyright clause, contains almost no discussion of the community interest in receiving political speech. Although Justice O'Connor's presumption against a fair use (and thus, by incorporation, first amendment) defense in cases of prepublication is designed to protect the artist, it would be troubling if the news were of immediate importance. For example, if Mr. Ford were up for re-election and the proposed publication date were after the election, the public's need to hear his explanation of the Nixon pardon would be particularly pressing.

The Court's emphasis on economic factors and its cavalier dismissal of the first amendment concerns of the community is ominous. Justice Brennan characterized the result as "risking the robust debate of public issues that is the 'essence of self-government." " 471 U.S. at 605 (Brennan, J., dissenting) (citation omitted). Nevertheless, I believe the Court reached the correct decision, but for the wrong reasons. If the Court simply had asked whether the infringement had been necessary to give the community a timely significant news story, it would have concluded that the infringement could not be justified. The story was significant, but there was no necessity for its immediate publication by the Nation. Time, a mass media publication, proposed to publish similar excerpts within a month of the Nation's publication date (a fact the Nation editor knew). Therefore, no unique substantial advantage to the public resulted from the Nation's infringement.

256. This was the concern expressed by Justice O'Connor in Harper \& Row, 471 U.S. at 559. In the context of news reporting, she commented, "[ilt is fundamentally at odds with the scheme of copyright to accord lesser rights in those works that are of greatest importance to the public." Id.

257. See supra notes $182-200$ and accompanying text. This is not to suggest that money is irrelevant to an artist's existence. William Fisher writes movingly of the "phenomenon-all too common in American literary history - of an unusually talented writer, financially strapped or simply discouraged by a meager income, producing less or poorer quality work than he is capable of." Fisher, supra note 9, at 1779. However, the examples he gives-Herman Melville, F. Scott Fitzgerald, Nathaniel Hawthorne, Henry James, Nathanael West, and Edmund Wilson, $i d$. at 1779 n.516, were not harmed by the fair use defense, but by general unpopularity of their work. The rcality is that most artistic work considered by the critics to be of the highest quality is not profitable. In the case of Susan, for example, it is highly unlikely that the sale of her poetry will ever provide her with a reasonable livelihood. See supra notes 176-79 and accompanying text. Only "popular" poets, such as good poets of comic verse, like Ogden Nash, and bad poets of sentimental verse, such as Rod McKuen, realize meaningful profits from their work. In short, whatever standard judges apply to the fair use defense will not solve the problem Fisher raises. The only realistic solution is some form of subsidization. See supra notes 201-06 and accompanying text.

As a result, two reasons dictate that the fair use defense should be applied to the highest quality artistic works:

1. In many instances, the artist actually will benefit from the use. See supra notes 215-17

and accompanying text. 
demic Susan, would actually welcome the widespread dissemination of their work that a communitarian fair use defense would bring. ${ }^{258}$

The understanding that the "public interest" served by copyright law is actually the cominumity interest would not be limited to the fair use defense. The duration limitation of copyright protection for intellectual property ${ }^{259}$ can be viewed as uniquely serving universal communal needs, as contrasted to nidividual autononious needs. Snice it is widely accepted that the ultimate test of a work of art is whether it endures through time, then the artist's works that are still sought after when they conne into the public domain will be the type of art that most enhances society's interests. All great works of art must belong eventually to the "ages," not to their original creator. ${ }^{260}$

The moral rights doctrine originated as a means of recognizing and protecting the uniquely strong bond between an artist's personatity and her creations. ${ }^{261}$ In a few modern variations, this doctrine has taken on a different cast: It also can serve as a ineans of protecting valuable artwork for the benefit of the public. Califorina's law of droit moral, for example, exphicitly is designed to preserve original paintings and sculptures as well as benefit artists. ${ }^{262}$

In ideal situations, both the concerns of the artist and the interests of the community are strengthened by the inoral rights doctrine. When it prevents a buyer from altering a statute or rewriting an original novel, almost everyone benefits. But the two interests do not always coincide. The inoral right of attribution is primarily neutral, but the rights of retraction, disclosure, and integrity can result in serious conflicts between the needs of the artist and the cominunity. Who should prevail, for example, when an artist's will orders the destruction of her paintings and an art expert challenges the will, declaring that the paintings are master-

2. In many instances, the benefit to the community will be substantial and the harm to the artist minimal.

258. See supra note 216 and accompanying text.

259. See supra notes 67-77 and accompanying text.

260. This is the best argument advanced for duration rules, and I will not attempt to refute it. Instead, I will try to extract a principle from its underlying assumptions that should apply to all forms of private property. If the value of a given piece of property to the community increases in time, the interests of the heirs of the original property holder correspondingly should decrease, until eventually the property should become part of the public domain. For example, now that the United States is no longer a forested wilderness, the value of remaining wilderness becomes greater and the comnunity's need for unspoiled national parks stronger.

261. See supra notes 86-88 and accompanying text.

262. See Damich, supra note 19 , at 1750 . Damich states that the California laws and New York laws have significantly different underlying philosophies. He notes that the New York statute, N.Y. ARTS \& Cultural AfFa1Rs LAw § 14.51:59 (McKinney 1984), does not nention the public interest, whereas the California statute's preamble explicitly recognizes "a public interest in preserving the integrity of cultural and artistic creations," CAL. CIV. CODE $\S 987$ (a) (West 1982 \& Supp. 1989). 
pieces that would become an integral part of the culture of the artist's homeland?263 Or when the Jewish author of a book describing her experiences in a Nazi concentration camp objects to the choice of an actress well known for her anti-Zionist views to play the author herself, claiming that this castimg offends the very spirit of the book?264

There are no perfect answers to conflicts between moral rights and the community, but a few basic principles should resolve many dilemmas.

1. Moral rights should not continue to exist after the artist's death. ${ }^{265}$ At that point, the bond between the artist and her work is broken or at least weakened, and the interest of the community in experiencing the work becomes paramount.

2. Moral rights are personal. They are not alienable and they cannot be vested in corporations. ${ }^{266}$

263. This example is drawn from the fact that Franz. Kafka asked his editor, Max Brod, to destroy all of his unpublished works upon his death. F. KAFKA, THE BAsic KAFKA ix (E. Heller ed. 1979). Brod did not do so, thus preserving for the public work which is widely acknowledged as being highly influential in modern Western literature.

264. This example is drawn from an actual incident involving the actress Vanessa Redgrave. For discussions of Ms. Redgrave's activities, see generally Serrill, Art Silenced or Preserved?, TIME, Nov. 12, 1984, at 88; Ford, An Artist Put on the Blacklist, NAT'L L.J., Nov. 12, 1984, at 13.

265. This principle is contrary to the doctrine's roots in France, where moral rights are perpetual. See supra note 90 . It is even slightly more restrictive than the Berne Convention, which extends moral rights protection until the end of copyright protection. See supra note 91 and accompanying text. Nevertheless, there are philosophical and practical concerns with creating a permanent personal moral right. Arguably, the bond between the artist and his work does expire with death. (The "truth" or "falsity" of the statement obviously cannot be determined, but one's religous views will influence one's views.) Even French law recognizes this concern, but resolves it by distinguishing between a moral right itself and the right to exercise the moral right. Da Silva, supra note 19, at 1415. It seems obvious that the artist alone is best suited to protect her work, but there seems to be no reason why her heirs (who would have the ability to consent to a work's alteration) are more suited to protect the work than a subsequent buyer. French law does allow an artist to transfer his moral rights to a third party, $\mathrm{Da}$ Silva, supra note 19 , at 15 , but this solution does not necessarily provide an argument for perpetual protection.

This conclusion may lead to some troubling results-an artist may destroy a work she does not wish viewed after her death, then change her mind-but on the whole it represents the best compromise betwecn the interests of the artist and the community. This conclusion does not prevent governments from passing laws that would permanently protect designated works of art from destruction, but such laws are not properly termed moral rights because they protect the artwork itself, not the artist. For example, the Massachusetts statute provides that if an artist has died, then the state's Attorney General may bring an action asserting the artist's right on behalf of the public. MASS. ANN. LAws ch. 231, $\S 85 S(g)$ (Law. Co-op. 1989).

266. This approach is consistent with Freneh law, which also states that the moral rights, even for works for hire, belong to the original creator, not the work's actual owner (the artist's employer). See supra note 90 . This approach is contrary to California law, see supra note 92 , but it seems to be the only logical interpretation of the personality theory. If the artist and her work are considered an inseparable unit, then the artist cannot sell the moral rights to her work just as she cannot sell herself into slavery. Although corporations may be "persons" in the eyes of the law, they are not human beings who will experience psychological suffering if their intellectual property is damaged. This principle would prevent results like the situation in which a corporation attempted to withhold docu- 
3. Moral rights are not absolute. The interests of society in health or safety should take precedence.

4. The right of integrity usually should be limited to the original work and authorized copies of that work. It should only extend to derivative works under exceptional circumstances, when the infringement of the right of integrity goes to the core of the original work and the coininuirity is not injured by assertion of the right. ${ }^{267}$

5. The right of withdrawal should be a limited one, at best. The author should not have a right to confiscate all old editions of her work. She can, however, prevent the work from being included in subsequent anthologies of her work and prevent new editions of the work from being issued. However, if the work is political in nature, even this right may be subject to the public's right to receive timiely, siginficant, political information. ${ }^{268}$

\section{CONCLUSION}

Monroe Price has suggested that "[t]here is reason for a reexamination of the doctrinal basis of intellectual property law .... [W] need to know whether our faith in historic assumptions is deserved ...."269 This Article is an attempt to begin that reexamination. I have argued that the current underlying assumptions of copyright law are seriously flawed. The fundamental justification for the very existence of intellectual property-the economic incentive for creation-does not reflect the complex-

ments in a tort case. See Blum, Copyright Used to Shield Discovery, NAT'L L.J., Mar. 28, 1988, at 3 (report of an attempt to withhold documents regarding jet skis in a products liability case by copyrighting the documents).

267. These rules would prevent an artist from asserting her right of integrity to prevent genuine parodies of her work. It is true that a particularly vicious parody indeed may cause psychological harm to a creative person, but parodies themselves are often works of art that can be of great value to the community. See Note, The Parody Defense to Copyright Infringement: Productive Fair Use After Betamax, 97 HARv. L. Rev. 1395 (1984) (suggesting an approach to fair use that accommodates the "conflicting claims of authors, parodists, and society").

The situation of the actress in the play about the concentration camp presents a different problem. There, the work was not a parody, but a purportedly faithful reproduction of the original. It was, however, only an adaptation of tlie book, whicl cuts in favor of a limited right of integrity. On the other hand, it is possible that a judge could find that the circumstances were exceptional. The very core of the book was conccrned witl tlie evils of anti-Semitism; the actress cliosen to play the author was, in the author's view, anti-Semitic. Equally significant, the substitution of another actress would not seriously damage the made-for-television inovie and the community's interest in seeing the movie would not be harmed. If this result could be viewed as a step toward blacklisting, then the community would be harmed. However, it is possible to view this example as a truly isolated incident. Only persons who wrote plays dealing witl anti-Semitism could object to Ms. Redgrave's casting on moral rights grounds; otlier autliors would not have that option.

268. Thus, a candidate for the Supreme Court would not be able to retract politically damaging law review articles, but an artist who is primarily a novelist with no political significance miglit be able to prevent additional publication of lis earlier works.

269. Price, supra note 12 , at 443 . In a later section of his essay, lie states, "[t]lie issue is whietlier continued reliance on the validity of assumptions about the extension of property rights provides tlie large scale answer to the intellectual property debates of the future." $I d$. at 456. 
ity of the world of artists and their real needs and motives. We must develop a better understanding of the reasons why artists create and consider other alternatives, such as an increased government subsidization of the arts. We also should recognize that the moral rights doctrine would protect both the artists and their work. I also contend that the term "public interest" standard as used by the commentators does not adequately distinguish between the autonomous interests of a large number of people and the sliared interests of a community.

Finally, I have shown that tle reasons intellectual property is treated differently from other forms of property cannot withstand close scrutiny. The spirit of altruism tliat permeates the language of copyright theory is indeed moving. But until we apply that selfless spirit and those persuasive reasons why intellectual property must be sliared with the community to other forms of property, we are being hypocritical at the expense of the artist and society. The anthem of the striking women textile workers, which lras become a feminist rallying cry, is right: We must have both bread and roses-one witlout the other never will be enough. 